Check for updates

Cite this: J. Mater. Chem. A, 2017, 5, 17676

Received 7th June 2017 Accepted 24th July 2017

DOI: $10.1039 / \mathrm{cta0} 4949 \mathrm{~h}$

rsc.li/materials-a

\section{Recent progress in nanostructured silver sulfide: from synthesis and nonstoichiometry to properties}

\begin{abstract}
S. I. Sadovnikov (D) * and A. I. Gusev (D) *
The microstructure (composition, nonstoichiometry, size and shape of particles) of nanostructured semiconductor silver sulfide $\left(\mathrm{Ag}_{2} \mathrm{~S}\right)$ determines its electronic structure, optical and electrical properties, and possible applications of $\mathrm{Ag}_{2} \mathrm{~S}$ in modern electronics, biology and medicine. This critical review summarizes recent progress in the design of different forms of nanostructured $\mathrm{Ag}_{2} \mathrm{~S}$ from nanopowders to colloidal solutions, quantum dots and heteronanostructures. Main results on the synthesis, structural features and properties of nanostructured $\mathrm{Ag}_{2} \mathrm{~S}$ are detailed. The appearance of nonstoichiometry in silver sublattices of monoclinic $\mathrm{Ag}_{2} \mathrm{~S}$ at decreasing size particles to the nanometer scale is considered. The interdependent changes in nonstoichiometry and crystal structure at the transformation of a nonconducting nanocrystalline $\mathrm{Ag}_{2} \mathrm{~S}$ in superionic conductors are discussed. The effects of nanocrystalline state on the peculiarities of crystal structure, nonstoichiometry, optical and thermal properties of semiconductor $\mathrm{Ag}_{2} \mathrm{~S}$ are considered. Special attention is paid to manifold applications of $\mathrm{Ag}_{2} \mathrm{~S}$-based nanomaterials and heteronanostructures in biomarkers, resistance-switches and nonvolatile memory devices.
\end{abstract}

\section{Introduction}

The synthesis and properties of nanostructured chalcogenides, including semiconducting lead sulfide (PbS), cadmium sulfide (CdS), mercury sulfide ( $\mathrm{HgS})$, copper(II) sulfide (CuS), $\mathrm{Cu}_{2} \mathrm{~S}$, and
Institute of Solid State Chemistry, Ural Branch of the Russian Academy of Sciences, 620990 Ekaterinburg, Russia.E-mail: sadovnikov@ihim.uran.ru; gusev@ihim.uran.ru

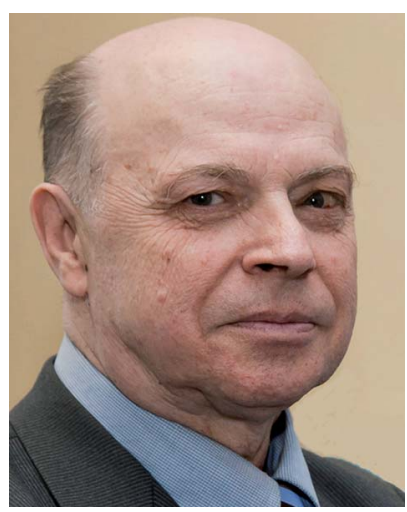

Professor Dr Aleksandr I. Gusev graduated in physical chemistry from the Ural State Technical University, Russia. He is Chief Research Scientist at the Laboratory of Nonstoichiometric Compounds in the Institute of Solid State Chemistry of the Ural Branch of the Russian Academy of Sciences. He has been exploring crystal and electronic structures and the properties of novel nonstoichiometric compounds such as carbides, sulfides, and oxides, and nanostructured advanced materials for more than 40 years. He is an author of 16 monographs including Disorder and Order in Strongly Nonstoichiometric Compounds (Springer, 2001), Nanocrystalline Materials (Cambridge, 2004), and Tungsten Carbides: Structure, Properties and Application in Hardmetals (Springer, 2013), 23 review articles and more than 350 scientific articles. His current interests lie in the materials science of nanostructured semiconductor sulfides. 
silver sulfide $\left(\mathrm{Ag}_{2} \mathrm{~S}\right)$, have been described in a number of review articles and books. ${ }^{1-10}$ However, too broad range of objects inevitably made the discussion too compact. Nanostructured $\mathrm{Ag}_{2} \mathrm{~S}$ has been mentioned in these works very briefly. Nonstoichiometry (i.e., deviation from stoichiometric composition) of $\mathrm{Ag}_{2} \mathrm{~S}$ has not been considered at all.

Nonstoichiometry is a fundamental characteristic of inorganic substances, which affects the structure and properties of compounds, on the one hand, and depends on the size of structural elements (particles, grains, crystallites, domains) of compounds, on the other hand. Until recently, the relationship and interdependence between nonstoichiometry and particle size at the nanometer scale has been scarcely examined or discussed only as an example of strongly nonstoichiometric compounds (e.g., carbides, oxides, nitrides of transition metals). Certainly the nonstoichiometry in nanostructured sulfides, which in the conventional bulk (coarse-grained) state are traditionally considered to be stoichiometric compounds, has never been discussed. Indeed, at present the number of studies devoted to nonstoichiometry of sulfide nanoparticles is extremely limited.

Modern solid-state physics, physical material science and electronics are inconceivable without semiconducting heterostructures. Such semiconducting heterostructures as quantum wells, quantum wires and quantum dots allow control of fundamental parameters of semiconducting crystals as the forbidden band width, effective mass and mobility of charge carriers and electronic energy spectrum. ${ }^{6,11-13}$ Heteronanostructures combining the properties of semiconductors in the nanocrystalline state, on the one hand, and nonstoichiometry, on the other hand, are the next step in the development of quantum electronics.

We have tried to take into account both the purely scientific, fundamental interest in the problem of nanostructured $\mathrm{Ag}_{2} \mathrm{~S}$ and some applied aspects of this problem that are of considerable importance for practical application of $\mathrm{Ag}_{2} \mathrm{~S}$.

The well-known $\mathrm{Ag}_{2} \mathrm{~S}$ is one of the most requisite semiconducting sulfides ${ }^{\mathbf{1 , 2 , 1 4 - 1 9}}$ along with lead, zinc, cadmium and copper sulfides..$^{3-5,20-25}$

$\mathrm{Ag}_{2} \mathrm{~S}$ is the only semiconducting sulfide (except for $\mathrm{HgS}$ ) having three polymorphous modifications $\left(\alpha-\mathrm{Ag}_{2} \mathrm{~S}, \beta-\mathrm{Ag}_{2} \mathrm{~S}\right.$ and $\gamma-\mathrm{Ag}_{2} \mathrm{~S}$ ) within rather close temperature intervals. ${ }^{\mathbf{2}}$ These modifications of $\mathrm{Ag}_{2} \mathrm{~S}$ differ greatly in their structure and properties. The unique character of $\mathrm{Ag}_{2} \mathrm{~S}$ has to do also with the transition between semiconducting $\alpha-\mathrm{Ag}_{2} \mathrm{~S}$ and superionic $\beta$ $\mathrm{Ag}_{2} \mathrm{~S}$ phases. The presence of this transformation makes it possible to use $\mathrm{Ag}_{2} \mathrm{~S}$ in $\mathrm{Ag}_{2} \mathrm{~S} / \mathrm{Ag}$ heteronanostructures intended for new-generation microelectronic devices such as resistance nanoswitches and nonvolatile memory nanodevices.

Low-temperature semiconducting-phase $\alpha-\mathrm{Ag}_{2} \mathrm{~S}$ (acanthite) with monoclinic crystal structure exists at temperatures below $\sim 450 \mathrm{~K}$. Under equilibrium conditions, cubic phase $\beta-\mathrm{Ag}_{2} \mathrm{~S}$ (argentite) exists in the temperature range 452-859 $\mathrm{K}$, has a body centered cubic (bcc) sublattice of sulfur (S) atoms and has a superionic conductivity. High-temperature cubic $\gamma-\mathrm{Ag}_{2} \mathrm{~S}$ phase with a face centered cubic (fcc) sublattice of $S$ atoms is stable from $\sim 860 \mathrm{~K}$ up to melting temperature.
It is thought that the monoclinic $\alpha-\mathrm{Ag}_{2} \mathrm{~S}$ phase is stoichiometric, whereas cubic $\beta-\mathrm{Ag}_{2 \pm \delta} \mathrm{S}$ and $\gamma-\mathrm{Ag}_{2 \pm \delta} \mathrm{S}$ with $\delta \cong 0.002$ are nonstoichiometric phases having either a small deficiency or small excess of silver. The homogeneity intervals of cubic allotropic forms of $\mathrm{Ag}_{2} \mathrm{~S}$ have been determined. ${ }^{27-33}$ According to, ${ }^{34}$ nonstoichiometric body centered cubic $\beta-\mathrm{Ag}_{2+\delta} \mathrm{S}$ $(\delta \leq 0.002)$ is characterized by high electronic conductivity of about $1.3 \times 10^{3} \Omega^{-1} \mathrm{~cm}^{-1}$ that is $10^{6}$ times higher than that in the monoclinic $\alpha-\mathrm{Ag}_{2} \mathrm{~S}$ phase. Owing to high electronic conductivity, bcc $\beta-\mathrm{Ag}_{2} \mathrm{~S}$ can be used in photography. ${ }^{34}$

In normal conditions, bulk coarse-crystalline $\mathrm{Ag}_{2} \mathrm{~S}$ with an $\alpha$ $\mathrm{Ag}_{2} \mathrm{~S}$ acanthite-type structure is a direct semiconductor which possesses a wide band gap $E_{\mathrm{g}}$ and low charge-carrier mobility. The band gap $E_{\mathrm{g}}$ of $\alpha-\mathrm{Ag}_{2} \mathrm{~S}$ depends on temperature. According to, ${ }^{35,36}$ the band gap of acanthite $\alpha-\mathrm{Ag}_{2} \mathrm{~S}$ at $300 \mathrm{~K}$ is about $0.9 \mathrm{eV}$, and its temperature coefficient $\partial E_{\mathrm{g}} / \partial T=-(1.2-1.5) \times 10^{-3} \mathrm{eV} \mathrm{K}^{-1} \cdot{ }^{36}$ The conventional band gap of acanthite $\alpha-\mathrm{Ag}_{2} \mathrm{~S}$ at $300 \mathrm{~K}$ is $0.9-1.1 \mathrm{eV}$.

For bulk coarse-crystalline acanthite $\alpha-\mathrm{Ag}_{2} \mathrm{~S}$, the electron and hole effective masses are $m_{\mathrm{e}}=0.286 m_{0}$ and $m_{\mathrm{h}}=1.096 m_{0}$, respectively. ${ }^{37}$ Taking this into account, the reduced exciton mass $\mu_{\mathrm{ex}}=m_{\mathrm{e}} m_{\mathrm{h}} /\left(m_{\mathrm{e}}+m_{\mathrm{h}}\right)$ for acanthite $\alpha-\mathrm{Ag}_{2} \mathrm{~S}$ is $\sim 0.23 m_{0}=$ $2.06 \times 10^{-31} \mathrm{~kg}$.

The characteristic size of the Wannier-Mott exciton (or the Bohr radius of the exciton) in the macroscopic (bulk) semiconductor has been determined to be

$$
R_{\mathrm{ex}} \approx n^{2} \hbar^{2} \varepsilon / \mu_{\mathrm{ex}} e^{2}=\left(n^{2} \varepsilon m_{0} / \mu_{\mathrm{ex}}\right) a_{\mathrm{B}}
$$

where $a_{\mathrm{B}}=\hbar^{2} / m_{0} e^{2}=0.0529 \mathrm{~nm}$ is the Bohr radius. For reduced exciton mass $\mu_{\mathrm{ex}}=0.23 m_{0}$ and dielectric constant $\varepsilon=5.95,{ }^{38}$ the radius $R_{\text {ex }}$ of the first exciton state with $n=1$ in coarsecrystalline acanthite $\alpha-\mathrm{Ag}_{2} \mathrm{~S}$ is equal to $(26 \pm 1) a_{\mathrm{B}}$ or $\sim 1.4 \pm$ $0.1 \mathrm{~nm}$ and the exciton diameter $D_{\mathrm{ex}}$ is about $2.8 \mathrm{~nm}$.

\section{Methods of synthesis of nanostructured $\mathrm{Ag}_{2} \mathrm{~S}$}

Nanostructured $\mathrm{Ag}_{2} \mathrm{~S}$ has been investigated intensively in recent years due to possible application in optoelectronics, biosensing and catalysis. ${ }^{39-42}$ It is an excellent substance for the preparation of heterostructures. ${ }^{43}$ Nanostructured $\mathrm{Ag}_{2} \mathrm{~S}$ can be used in photochemical cells, ${ }^{44}$ infrared detectors ${ }^{45-47}$ in resistanceswitches and nonvolatile memory devices. ${ }^{4-50} \mathrm{Ag}_{2} \mathrm{~S}$ is a promising material for conversion of solar energy into electrical energy. ${ }^{51,52}$ Recently, three-dimensional nanoparticle superlattices were built up with $\mathrm{Ag}_{2} \mathrm{~S}$ hollow nanospheres and nanodiscs as building blocks. ${ }^{53} \mathrm{Ag}_{2} \mathrm{~S}$ nanoparticles possess antibacterial action. ${ }^{\mathbf{5 4 5 5}}$ Creation of isolated, stable $\mathrm{Ag}_{2} \mathrm{~S}$ quantum dots to be used as biomarkers holds much promise. ${ }^{56,57}$

Nanostructured silver chalcogenides including $\mathrm{Ag}_{2} \mathrm{~S}$ also have been showing promising applications in thermoelectrics. ${ }^{\mathbf{5}}$ The thermoelectric effect refers to phenomena by which either a temperature difference creates an electric potential or an electric potential creates a temperature difference. The dimensionless figure of merit (thermoelectric performance) $Z T$ of any material is determined as $\sigma S^{2} T / \kappa$, where $\sigma$ is the electrical 
conductivity, $S$ is the Seebeck coefficient, $\kappa$ is the thermal conductivity of the material, and $T$ is the absolute temperature. Tellurides, selenides, sulfides, and their solid solutions are the most attractive thermoelectric materials. ${ }^{58-61}$ Silver chalcogenides $\mathrm{Ag}_{2} \mathrm{Se}$ and $\mathrm{Ag}_{2} \mathrm{~S}$ have attracted much interest due to reversible transformation between semiconductor and superionic phases. In study, ${ }^{58}$ it has been shown that the Seebeck coefficient and $Z T$ for $\mathrm{Ag}_{2} \mathrm{~S}$ nanocrystal are equal to $-76 \mu \mathrm{V} \mathrm{K}^{-1}$ and 0.12 at the temperature of the transition from $\alpha-\mathrm{Ag}_{2} \mathrm{~S}$ to $\beta$ $\mathrm{Ag}_{2} \mathrm{~S}$. For nanocrystalline $\mathrm{Ag}_{2} \mathrm{Se}$ and $\mathrm{Ag}_{4} \mathrm{SeS}$, values of $Z \mathrm{~T}$ are 0.23 and 0.33 , respectively. According to,$^{60}$ the Seebeck coefficient of $\mathrm{Ag}_{2} \mathrm{~S}$ nanocrystalline film is $-198 \mu \mathrm{V} \mathrm{K} \mathrm{K}^{-1}$ at $400 \mathrm{~K}$; therefore, enhanced $Z T$ for $\mathrm{Ag}_{2} \mathrm{~S}$ nanofilms can be anticipated. According to ${ }^{\mathbf{5}}$ the cooperative contribution of superionic phase transition, reduced grain size, and alloying opens up a promising new approach to "tailor" sulfide materials for optimal thermoelectric performance.

Nanostructured $\mathrm{Ag}_{2} \mathrm{~S}$ in the form of nanopowders, quantum dots, and heteronanostructures based on $\mathrm{Ag}_{2} \mathrm{~S}$ has been successfully produced by different methods such as hydrochemical deposition, template method, sol-gel method, synthesis in microemulsions, as well as by sonochemical, hydrothermal, solvothermal, electrochemical, microwave and other techniques. Every method has both advantages and limitations.

Sodium sulfide $\left(\mathrm{Na}_{2} \mathrm{~S}\right)^{30,40,62-68}$ hydrogen sulfide gas or hydrosulfuric acid $\left(\mathrm{H}_{2} \mathrm{~S}\right){ }^{69}$ elemental $\mathrm{S}$ dissolved in a concentrated $\mathrm{NaOH}$ solution, ${ }^{70}$ solution of toxic carbon disulfide $\left(\mathrm{CS}_{2}\right)$ in ethanol, ${ }^{71-74}$ sodium thiosulfate $\left(\mathrm{Na}_{2} \mathrm{~S}_{2} \mathrm{O}_{3}\right),{ }^{75}$ a solution of 3-thiopropionic-(3-mercaptopropionic) acid $\left(\mathrm{C}_{3} \mathrm{H}_{6} \mathrm{O}_{2} \mathrm{~S}\right)$ in ethylene glycol (EG) as solvent, ${ }^{56}$ thiocarbamide $\left(\mathrm{N}_{2} \mathrm{H}_{4} \mathrm{CS}\right),{ }^{52,53,76,77}$ and thioacetamide $\left(\mathrm{CH}_{3} \mathrm{C}(\mathrm{S}) \mathrm{NH}_{2}\right)^{78}$ and their derivatives are used for sulfidizing the soluble complex compounds of $\mathrm{Ag}$ and other metals.

Recently, much attention has been devoted to the production of different hybrid heteronanostructures of the core-shell type, which include $\mathrm{Ag}$ and its compounds $\left(\mathrm{Ag}_{2} \mathrm{O} @ \mathrm{Ag}_{2} \mathrm{~S}\right.$, $\mathrm{Ag} @ \mathrm{SiO}_{2}$, etc. .). ${ }^{79-81}$ In particular, familiar core-shell nanostructures can be formed by two different semiconductors (CdSe@CdS, CdSe@ZnS, CdS@Ag $2 \mathrm{~S}$, CdS@ZnS, GaAs@Als, etc.). ${ }^{82-86}$

The nanosized particles are not stable. The high surface energy will impel the nanoparticles to aggregate. Therefore, creation of core-shell particles can be due to the necessity of fixing of specific groups (organic ligands) on the surface of the core, which would prevent agglomeration, growth, and oxidation of particles and provide the production of stable isolated nanoparticles. Using the protective shell, it is possible to control the size of isolated nanoparticles. Stabilizing and capping agents such as trioctylphosphine oxide, ${ }^{87,88}$ L-cysteine, ${ }^{89-91}$ glutathione, ${ }^{92}$ long-chain amines (hexadecylamine, octylamine, dioctylamine, ethylenediamine), ${ }^{39}$ ethylenediaminetetraacetic acid (EDTA) and $\mathrm{EG}^{75,93}$ are used for the creation of a protective shell. However, most of the listed stabilizing agents are hazardous to human health and have a serious impact on the environment. One of the most commonly requested non-toxic capping agents which has a high degree of electrostatic stabilization is sodium citrate $\left(\mathrm{Na}_{3} \mathrm{C}_{6} \mathrm{H}_{5} \mathrm{O}_{7} \equiv \mathrm{Na}_{3} \mathrm{Cit}\right){ }_{.}^{55,68,69,94-96}$

Several investigations ${ }^{97-100}$ have shown that extracts or aqueous solutions of natural products (leaves, seeds, fruits, roots, honey, royal jelly, gum of trees, bovine serum albumin, etc.) can be used as stabilizing agents for the preparation of isolated nanoparticles of $\mathrm{Ag}_{2} \mathrm{~S}$ and $\mathrm{Ag}$ with a protective shell. Such exotic stabilizing agents are non-toxic and do not exert a harmful impact on the environment due to their high antioxidant potential. However, the complete identification of the complex composition of listed natural stabilizing agents has been an open and undecided problem until now. Therefore, real application of natural stabilizing agents is rather limited.

The most pronounced part in the formation of $\mathrm{Ag}_{2} \mathrm{~S}$ nanoparticles has been played by complexing agents. $\mathrm{Na}_{3} \mathrm{Cit}$ is the main complexing agent for $\mathrm{Ag}^{+}$. One must point out that the $\mathrm{Na}_{3} \mathrm{Cit}$ is the completely harmless standardized food additive E331.

\subsection{Synthesis by decomposition of molecular precursors}

Application of molecular precursors has some attractive features. On the one hand, it provides such important advantages as simplicity, safety and compatibility with metal organic chemical vapor deposition. ${ }^{\mathbf{1 0 1}}$ On the other hand, the use of molecular precursors may lead to the unusual selectivity in crystal growth or formation of the metastable phase of the final products, which are not always achievable by conventional synthetic methods.

Among the solution methods, the injection of an organometallic precursor into a hot solvent provides a simple route to produce particles with desirable properties (e.g., high crystallinity, and uniform shapes and sizes with a high degree of monodispersity).

Lim et $a .^{39}$ discovered that air-stable precursors such as silver thiobenzoate $(\mathrm{Ag}(\mathrm{SCOPh}))$ meets these requirements. The precursor crystals were found to decompose in amine at room temperature to give $\mathrm{Ag}_{2} \mathrm{~S}$ nanoparticles. The most important parameters of synthesis are the reaction temperature, type of amine, relative concentration of the reagents, and reaction time. Lim et $a{ }^{39}$ found that by increasing the injection temperature to $393 \mathrm{~K}$, cube-shaped $\mathrm{Ag}_{2} \mathrm{~S}$ nanocrystals are obtained exclusively (Fig. 1). The uniform $\mathrm{Ag}_{2} \mathrm{~S}$ nanocubes selfassemble into ordered two-dimensional arrays on the surface of the transmission electron microscope grid (Fig. 1a). The average size of these nanocubes is $44 \pm 4 \mathrm{~nm}$. The scanning electron microscopy (SEM) image in Fig. 1b illustrates that large quantity of these nanocubes can be obtained using this approach. High-resolution transmission electron microscopy (HRTEM) images (Fig. 1c and d) clearly show that $\mathrm{Ag}_{2} \mathrm{~S}$ nanocubes are single crystals.

Later, spherical $\mathrm{Ag}_{2} \mathrm{~S}$ nanocrystals were obtained via a modified hot-injection process of the same single-source molecular precursor $\mathrm{Ag}(\mathrm{SCOPh})$, which can potentially generate both $\mathrm{Ag}^{*}$ and $\mathrm{AgS}$ * fragments simultaneously. ${ }^{\mathbf{1 0 2}}$ Wang et al. ${ }^{103}$ obtained $\mathrm{Ag}_{2} \mathrm{~S}$ nanocrystallites by heating molecular precursors such as silver diethyldithiocarbamate (Ag-DDTC) in air at $473 \mathrm{~K}$ for $3 \mathrm{~h}$, and used this air-stable molecular precursor 


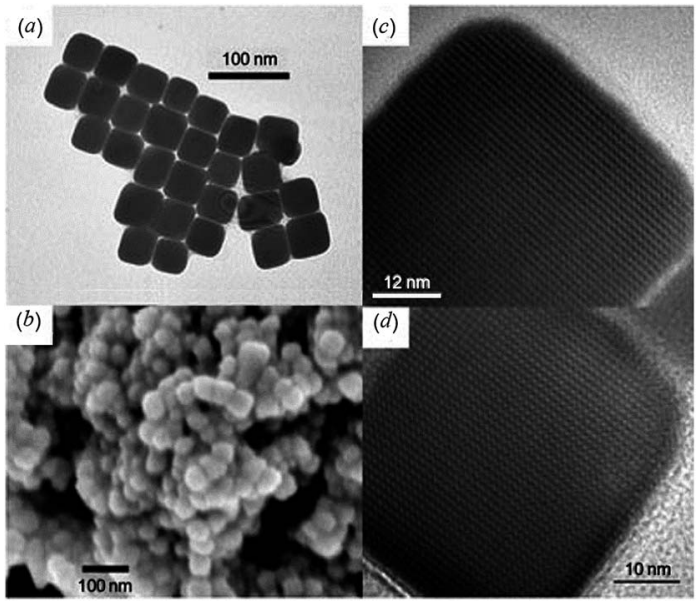

Fig. $1 \mathrm{Ag}_{2} \mathrm{~S}$ nanocubes produced at $393 \mathrm{~K}:{ }^{39}$ (a) TEM image of $\mathrm{Ag}_{2} \mathrm{~S}$ nanocubes; (b) SEM image of clusters formed by $\mathrm{Ag}_{2} \mathrm{~S}$ nanocubes; (c) and (d) HRTEM images of $\mathrm{Ag}_{2} \mathrm{~S}$ nanocubes. Reproduced from ref. 139 with permission from Wiley.

as the reactant source. The proposed method was both costeffective and non-toxic. Monodisperse $\mathrm{Ag}_{2} \mathrm{~S}$ nanoparticles with controlled size were successfully synthesized by thermolysis of harmless silver xanthates as a single-source molecular precursor. ${ }^{104}$ In one experiment, ${ }^{104}$ the diameter of the $\mathrm{Ag}_{2} \mathrm{~S}$ nanoparticles ranged from $8.9 \pm 1.2 \mathrm{~nm}$ to $48 \pm 4 \mathrm{~nm}$ (Fig. 2). Control of the particle size has been achieved by simply changing the alkyl chain length in the precursors.

\subsection{Synthesis of nanostructured $\mathrm{Ag}_{2} \mathrm{~S}$ with different morphology}

Recently, great efforts have been focused on the preparation of $\mathrm{Ag}_{2} \mathrm{~S}$ nanoparticles of various morphology, and on the morphology control of the semiconductor nanocrystals. ${ }^{105}$ For example, Zhao et al. ${ }^{106}$ prepared rod-like $\mathrm{Ag}_{2} \mathrm{~S}$ nanocrystals using $\mathrm{Na}_{2} \mathrm{~S}_{2} \mathrm{O}_{3}$ as a $\mathrm{S}$ source via gamma-ray irradiation of aqueous solutions at room temperature.

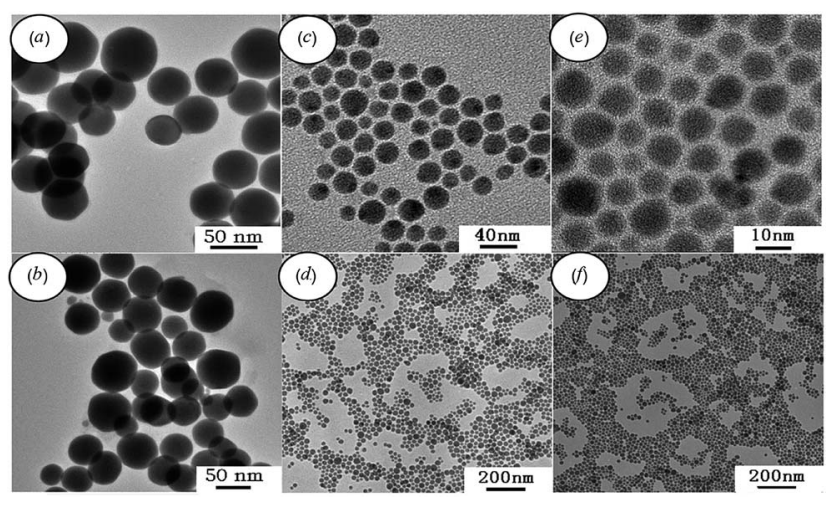

Fig. 2 TEM images of $\mathrm{Ag}_{2} \mathrm{~S}$ nanoparticles synthesized by solvent-less thermolysis of ( $a$ and $b$ ) silver octyl xanthate, ( $c$ and d) silver hexadecyl xanthate, and (e and f) silver carnaubyl xanthate. Reprinted from ref. 104 with permission from Elsevier.
An alcohol solution method to synthesize nanostructured $\mathrm{Ag}_{2} \mathrm{~S}$ using carbon bisulfide $\left(\mathrm{CS}_{2}\right)$ as the $\mathrm{S}$ source has been described. ${ }^{107}$ All the products were irregular $\mathrm{Ag}_{2} \mathrm{~S}$ microstructures and nanostructures. When the reaction medium was changed from water and alcohol-water to alcohol, the morphology of synthesized $\mathrm{Ag}_{2} \mathrm{~S}$ changed from big irregular nanosheets to leaf-like nanosheets, elliptical, and Y-shaped flaked $\mathrm{Ag}_{2} \mathrm{~S}$ nanoparticles.

Later, Chen et al. ${ }^{108}$ reported that leaf-like $\mathrm{Ag}_{2} \mathrm{~S}$ nanosheets were prepared successfully by a facile hydrothermal method from a mixture of alcoholic $\mathrm{CS}_{2}$ solution with an aqueous solution of $\mathrm{AgNO}_{3}$ and $\mathrm{NH}_{3}$.

$\mathrm{Ag}_{2} \mathrm{~S}$ microstructures and nanostructures with different morphologies, including micrometer bars, nanowires, and nanopolyhedrons, have been synthesized by a facile one-step method at room temperature. ${ }^{\mathbf{1 0 9}}$ In the proposed method, no organic template materials were added to the reaction mixture, which contained aqueous solutions of $\mathrm{AgNO}_{3}, \mathrm{NH}_{3}$, and $\mathrm{N}_{2} \mathrm{H}_{4}$ CS. By changing the reactant concentration ratio, the size and morphology of prepared $\mathrm{Ag}_{2} \mathrm{~S}$ particles can be easily tuned.

In recent years, polyhedral nanocrystals, including facecentered cubic sulfide nanocrystals, ${ }^{39,110}$ have been successfully fabricated. Wang et al. ${ }^{\mathbf{1 1 0}}$ prepared $\mathrm{Ag}_{2} \mathrm{~S}$ nanocrystals by thermolysis of an organometallic precursor $\mathrm{Ag}\left[\mathrm{S}_{2} \mathrm{P}(\mathrm{OR})_{2}\right]$ $\left(\mathrm{R}=\mathrm{C}_{n} \mathrm{H}_{2 n+1}\right)$. The above-mentioned hydrothermal method has been improved by Dong et al. ${ }^{111}$ Most of the observed $\mathrm{Ag}_{2} \mathrm{~S}$ nanoparticles looked hexagonal.

$\mathrm{Ag}_{2} \mathrm{~S}$-poly( $\mathrm{N}$-isopropylacrylamide-co-methacrylic acid) (PNIPAM-MAA) and $\mathrm{Ag}_{2} \mathrm{~S}$-PNIPAM composite microspheres with patterned surface structures have been synthesized by a polymeric minigel template method. ${ }^{112}$ The surface structure of $\mathrm{Ag}_{2} \mathrm{~S}$-PNIPAM-MAA microspheres looks like flowers.

Single-crystalline $\mathrm{Ag}_{2} \mathrm{~S}$ hollow nanohexagons with narrow size distribution were successfully synthesized in aqueous solutions of $\mathrm{AgNO}_{3}, \mathrm{~N}_{2} \mathrm{~S}_{2} \mathrm{O}_{3}$, and $\mathrm{C}_{19} \mathrm{H}_{42} \mathrm{BrN}$ (CTAB) at $318 \mathrm{~K}^{113}$

Tetrahedral colloidal crystals of $\mathrm{Ag}_{2} \mathrm{~S}$ nanoparticles have been synthesized from aqueous solutions of $\mathrm{AgNO}_{3}, \mathrm{NH}_{3}$, and 1-dodecanethiol $\left(\mathrm{CH}_{3}\left(\mathrm{CH}_{2}\right)_{11} \mathrm{SH}\right)$ in an autoclave at $473 \mathrm{~K}$ for 5 h. ${ }^{114}$ Due to the high uniformity and van der Waals interactions, $\mathrm{Ag}_{2} \mathrm{~S}$ nanoparticles spontaneously assemble into tetrahedral colloidal aggregates comprising a perfectly ordered $3 \mathrm{D}$ superlattice structure (Fig. 3).

A sacrificial core of $\mathrm{S}$ nanoparticles is used to synthesize $\mathrm{Ag}_{2} \mathrm{~S}$ hollow nanospheres via a wet chemical method at room temperature. ${ }^{115} \mathrm{~S}$ nanoparticles as cores were synthesized from $\mathrm{Na}_{2} \mathrm{~S}_{2} \mathrm{O}_{3}$ in the presence of cetyltrimethyl ammonium bromide aqueous solution. After completion of the formation of cores, the $\mathrm{AgNO}_{3}$ solution was added. Then, the produced particles were washed by a water-ethanol mixture and treated with $\mathrm{CS}_{2}$ for the complete conversion of $\mathrm{AgBr}$ to $\mathrm{Ag}_{2} \mathrm{~S}$, as well as to remove the cores to form $\mathrm{Ag}_{2} \mathrm{~S}$ hollow nanospheres (Fig. 4).

Worm-like $\mathrm{Ag}_{2} \mathrm{~S}$ nanofibers with lengths up to several micrometers and diameters of 25-50 $\mathrm{nm}$ have been prepared in reverse microemulsions in the presence of $\mathrm{CH}_{3} \mathrm{C}(\mathrm{S}) \mathrm{NH}_{2}$ as a $\mathrm{S}$ source and EDTA as a chelating ligand. ${ }^{116}$

In study, ${ }^{117}$ rice-shaped $\mathrm{Ag}_{2} \mathrm{~S}$ nanoparticles were produced by the reaction between $\mathrm{Ag}\left(\mathrm{NH}_{3}\right)_{2}{ }^{+}$and $\mathrm{Na}_{2} \mathrm{~S}$ in the presence of 

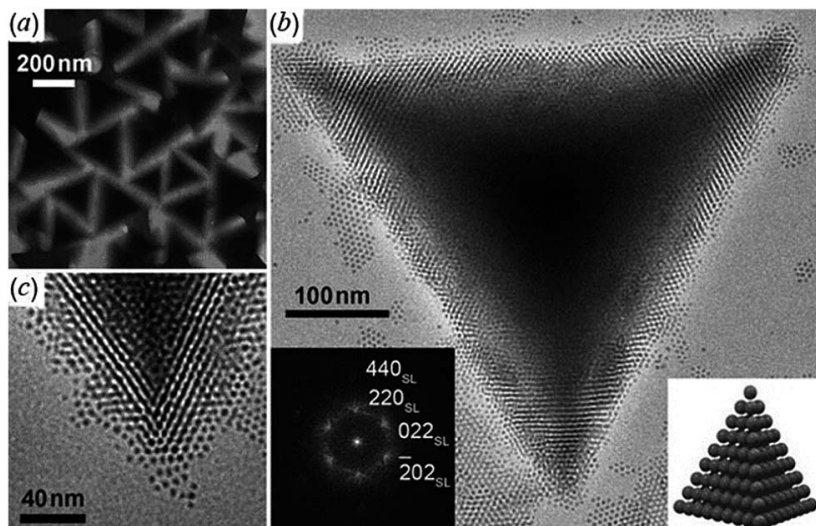

$100 \mathrm{~nm}$
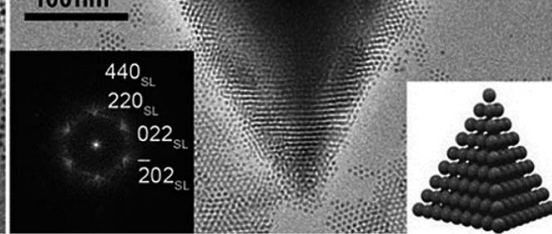

Fig. $3 \mathrm{Ag}_{2} \mathrm{~S}$ tetrahedral superlattice colloidal crystals: ${ }^{: 14}$ (a) TEM image at low magnification; (b) a typical HRTEM image of an individual tetrahedron at high magnification; the left inset is the diffraction pattern calculated using fast Fourier transform (FFT) of HRTEM images and the right inset is a scheme of the tetrahedral superlattice colloidal crystal; (c) magnified TEM image of a vertex of the tetrahedron. Reproduced from ref. 114 with permission from Wiley.

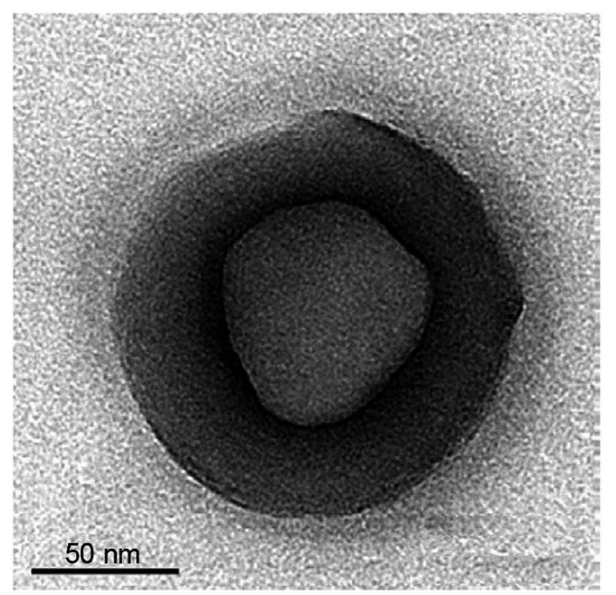

Fig. 4 TEM image of a hollow $\mathrm{Ag}_{2} \mathrm{~S}$ particle synthesized from a reaction mixture of silver nitrate and thiosulfate. Reprinted from ref. 115 with permission from Elsevier.

polyvinylpyrrolidone $\left(\mathrm{C}_{6} \mathrm{H}_{9} \mathrm{NO}\right)_{n}(\mathrm{PVP})$ through a hydrothermal method.

Large, rice-shaped $\mathrm{Ag}_{2} \mathrm{~S}$ particles have been synthesized by hydrochemical bath deposition from aqueous reaction mixture of silver nitrate $\left(\mathrm{AgNO}_{3}\right), \mathrm{Na}_{2} \mathrm{~S}$, and $\mathrm{Na}_{3} \mathrm{Cit}^{1{ }^{118}}$ Reaction mixture was heated in closed vessel at a temperature of $373 \mathrm{~K}$ under the pressure $\sim 2 \times 10^{5}$ Pa within $2 \mathrm{~h}$.

\subsection{Synthesis of $\mathrm{Ag}_{2} \mathrm{~S}$ nanowires}

The one-dimensional (1D) nature of $\mathrm{Ag}_{2} \mathrm{~S}$ nanowires endows their unique electrical, optoelectronic, and mechanical properties. Single-crystalline $\mathrm{Ag}_{2} \mathrm{~S}$ nanowires can be expected to have superior properties owing to their anisotropic geometry, and carrier and photon confinement in two dimensions.
Conventional nanowire synthesis often requires high temperature and/or various templates.

According to, ${ }^{119,120}$ there are two different routes for the synthesis of 1D nanomaterials, namely, "hard" and "soft" approaches. The first approach includes template-directed synthesis and the vapor-liquid-solid and vapor-solid techniques, which usually require high temperature and pressure. In comparison, the soft approaches, such as hydrothermal/ solvothermal processes, the solution-liquid-solid mechanism, and capping agents/surfactant-assisted synthesis, provide a convenient and low-temperature pathway for the fabrication of 1D nanomaterials.

Recently, $\mathrm{Ag}_{2} \mathrm{~S}$ nanowires have been synthesized through the gas-solid reaction route, ${ }^{121}$ anodic aluminum oxide template method, ${ }^{122}$ microwave irradiation-assisted method, ${ }^{123}$ and hydrothermal method with amine ligand. ${ }^{\mathbf{1 2 0}}$

Wen et al. ${ }^{121}$ reported on the successful synthesis of $\mathrm{Ag}_{2} \mathrm{~S}$ nanowires by a simple and mild gas-solid reaction method on $\mathrm{Ag}$ substrates. For the nanowire synthesis, the cleaned $\mathrm{Ag}$ foil was subjected to preoxidation and sulfidizing by an exposition in an atmosphere of an $\mathrm{O}_{2} / \mathrm{H}_{2} \mathrm{~S}$ mixture from room temperature to $313 \mathrm{~K}$ in a water bath. The resulting $\mathrm{Ag}_{2} \mathrm{~S}$ nanowires contained one-phase monoclinic acanthite $\alpha-\mathrm{Ag}_{2} \mathrm{~S}$ and had diameter of 40-150 $\mathrm{nm}$ and lengths up to $100 \mu \mathrm{m}$.

In other syntheses, ${ }^{120} \mathrm{AgNO}_{3}$ was dissolved in warm octadecylamine solvent, forming silver ammines that were rapidly converted to $\mathrm{Ag}_{2} \mathrm{~S}$ nuclei upon the addition of $\mathrm{S}$ powder. After stirring, the system was maintained at $393 \mathrm{~K}$ for further growth and crystallization. This process resulted in the generation of ultralong $\mathrm{Ag}_{2} \mathrm{~S}$ nanowires with diameters in the range of $10-30 \mathrm{~nm}$ and lengths up to hundreds of micrometers. Authors ${ }^{120}$ could only obtain uniform nanowires at a temperature neither lower nor higher than $393 \mathrm{~K}$. Synthesized $\mathrm{Ag}_{2} \mathrm{~S}$ nanowires are very sensitive to oxygen and there is a quasi-linear ratio between the current and the logarithm of oxygen pressure. These excellent performances indicate that $\mathrm{Ag}_{2} \mathrm{~S}$ nanowires are promising candidates for photoswitches and room-temperature oxygen sensors.

In work, ${ }^{124} \mathrm{Ag}_{2} \mathrm{~S}$ nanowires were prepared in anhydrous ethanol through a simple and sacrificial templating solvothermal route. The experimental results ${ }^{124}$ demonstrated that the reaction temperature, $\mathrm{Ag}^{+}$concentration, reaction time and solvent played crucial parts in the formation of the $\mathrm{Ag}_{2} \mathrm{~S}$ nanowires. In a typical procedure, a mixture of $\mathrm{S}$ powder and $\mathrm{Cd}\left(\mathrm{CH}_{3} \mathrm{COO}\right)_{2}$ were dissolved consecutively in ethylenediamine. The resulting mixture was heated in the autoclave at $473 \mathrm{~K}$ for $2 \mathrm{~h}$. Then, as-prepared CdS nanowires and $\mathrm{AgNO}_{3}$ were dissolved in anhydrous ethanol. The resulting mixture was heated in the autoclave at 473 $\mathrm{K}$ for $12 \mathrm{~h}$. The addition of excess $\mathrm{Ag}^{+}$leads to the complete transformation of $\mathrm{CdS}$ nanowires to the $\mathrm{Ag}_{2} \mathrm{~S}$ nanowires.

Later, ${ }^{125}$ a cation-exchange process was used for fabrication of $\mathrm{Ag}_{2} \mathrm{~S}$ nanowires. Authors ${ }^{125}$ reported a sequential two-step cation exchange process which transformed single-crystal nanowires to twinning nanowires. Specifically, CdS nanowires were used as a template to form $\mathrm{CdS}-\mathrm{Cu}_{2} \mathrm{~S}$ core shell nanowires and subsequently twinning $\mathrm{Cu}_{2} \mathrm{~S}$ nanowires through cation exchange. Then, twinning $\mathrm{Cu}_{2} \mathrm{~S}$ nanowires were transformed to $\mathrm{Cu}_{2} \mathrm{~S}-\mathrm{Ag}_{2} \mathrm{~S}$ superlattice nanowires with tunable segment 
lengths via further cation exchange of $\mathrm{Cu}^{+}$by $\mathrm{Ag}^{+}$. Fig. 5 shows the schematic synthetic sequence to form $\mathrm{Cu}_{2} \mathrm{~S}-\mathrm{Ag}_{2} \mathrm{~S}$ superlattice nanowires from CdS nanowires. Thus, authors ${ }^{\mathbf{1 2 5}}$ have demonstrated that twins created in the cation exchange process of nanowires can be utilized to generate heterostructures in the chain cation exchange steps.

\subsection{Preparing $\mathrm{Ag}_{2} \mathrm{~S}$ nanoparticles and quantum dots}

$\mathrm{Ag}_{2} \mathrm{~S}$ quantum dots are treated as an ideal optical probe with fluorescence emission from UV to NIR region because these quantum dots have lower toxicity compared with chalcogenide quantum dots of such heavy metals as $\mathrm{Pb}, \mathrm{Ca}$, and $\mathrm{Hg} .{ }^{\mathbf{1 2 6}, 127}$ The synthesis of quantum dots, which can be used as optical probes for in vitro and in vivo molecular imaging, has made great progress. ${ }^{128}$ The first synthesis of $\mathrm{Ag}_{2} \mathrm{~S}$ quantum dots with emission in the NIR-II region was demonstrated by Du and coauthors. ${ }^{127}$ In a typical reaction, Ag-DDTC was mixed with oleic acid $\left(\mathrm{CH}_{3}\left(\mathrm{CH}_{2}\right)_{7} \mathrm{CH}=\mathrm{CH}\left(\mathrm{CH}_{2}\right)_{7} \mathrm{COOH}\right)$, 1-octadecane $\left(\mathrm{CH}_{3}\left(\mathrm{CH}_{2}\right)_{16} \mathrm{CH}_{3}\right)$ and octadecylamine $\left(\mathrm{CH}_{3}\left(\mathrm{CH}_{2}\right)_{17} \mathrm{NH}_{2}\right)$.

In study, ${ }^{\mathbf{1 2 9}}$ highly monodisperse and water-soluble clusters representing $\mathrm{Ag}_{2} \mathrm{~S}$ quantum dots, covered by ribonuclease-A, were synthesized in aqueous medium via a biomimetic route (i.e., by a method that mimics biochemical processes).

Siva et al. $^{130}$ noted that the biomolecules assisted the formation of inorganic nanostructures, facilitated electrostatic stabilization, and improved the optical properties of nanoparticles. In study, ${ }^{\mathbf{1 3 0}}$ aqueous solutions of $\mathrm{AgNO}_{3}$ and aurochloric acid $\left(\mathrm{HAuCl}_{4}\right)$ and also a solution of $\mathrm{L}$-cysteine in a mixture of water, ethylene glycol, and ethanol were used for synthesis of L-cysteine-capped $\mathrm{Ag}_{2} \mathrm{~S}$ and $\mathrm{Ag}_{3} \mathrm{AuS}_{2}$ nanocrystals. $\mathrm{Ag}_{2} \mathrm{~S}$ nanocrystals were prepared using $\mathrm{Ag}$ nuclei as a core. Siva et al. ${ }^{130}$ proposed the following scheme of formation of $\mathrm{Ag}_{2} \mathrm{~S}$ particles:

$$
\begin{aligned}
& \quad \mathrm{Ag}^{+}+\mathrm{L} \text {-cysteine } \stackrel{298 \mathrm{~K}}{\longrightarrow}\left[\mathrm{Ag}(\text { L-cysteine })_{n}\right]^{+}, \\
& {\left[\mathrm{Ag}(\mathrm{L} \text {-cysteine })^{n}\right]^{+}} \\
& +\mathrm{OH}^{-} \stackrel{\text { ethanol decomposition, 343 K }}{\longrightarrow} \text { L-cysteine-capped Ag, }
\end{aligned}
$$$$
\text { L-Cysteine capped } \mathrm{Ag} \stackrel{\mathrm{C}-\mathrm{S} \text { bond rupture, } 343 \mathrm{~K}}{\longrightarrow} \mathrm{Ag}_{2} \mathrm{~S} \text {. }
$$

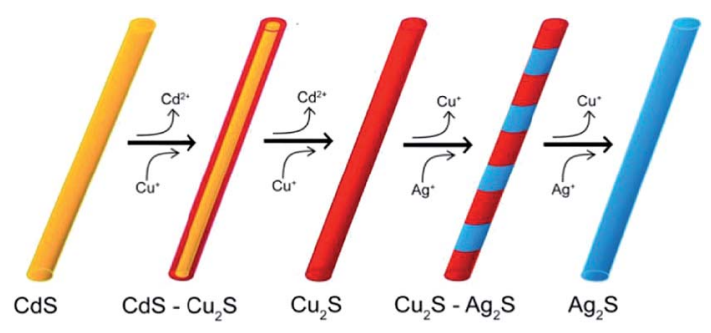

Fig. 5 Chain cation exchange process for the formation of a $\mathrm{Cu}_{2} \mathrm{~S}-$ $\mathrm{Ag}_{2} \mathrm{~S}$ superlattice NWs. Reprinted from ref. 125 with permission from ACS.
There are many other methods for synthesis of nanostructured $\mathrm{Ag}_{2} \mathrm{~S}$. In study, ${ }^{\mathbf{1 3 1}} \mathrm{Ag}_{2} \mathrm{~S}$ nanoparticles were prepared by pyrolysis using $\mathrm{AgNO}_{3}$ and $\mathrm{S}$ powder as precursors, and oleylamine $\mathrm{C}_{18} \mathrm{H}_{35} \mathrm{NH}_{2}$ as a solvent. Oleylamine acts as both a reducing agent and stabilizer during the synthesis. $\operatorname{Ag}_{2} \mathrm{~S}$ nanoparticles of uniform size were prepared by controlling the ratio amounts of $\mathrm{AgNO}_{3}: \mathrm{S}$ and ripening time.

Shakouri-Arani and Salavati-Niasari ${ }^{\mathbf{1 3 2}}$ produced $\mathrm{Ag}_{2} \mathrm{~S}$ nanoparticles by a solvothermal process via reaction of $\mathrm{AgNO}_{3}$ and a new sulfuring agent from the class of thio Schiff-base (2(benzylidene amino)benzenethiol $\mathrm{C}_{13} \mathrm{H}_{11} \mathrm{NS}$ ) in the presence of various solvents.

Nanostructured $\mathrm{Ag}_{2} \mathrm{~S}$ was obtained in the absence of a surfactant or presence of an anionic surfactant such as sodium dodecyl sulfate $\left(\mathrm{C}_{12} \mathrm{H}_{25} \mathrm{SO}_{4} \mathrm{Na}\right.$; SDS) or such cationic surfactants as CTAB and polyethylene glycol (PEG) $20000 \mathrm{C}_{2 n^{-}}$ $\mathrm{H}_{4 n+2} \mathrm{O}_{n+1}$ ( $\left.\mathrm{HO}-\left(\mathrm{C}_{2} \mathrm{H}_{4} \mathrm{O}\right)_{n}-\mathrm{H}\right)$. Surfactants were dissolved in solvents such as $\mathrm{H}_{2} \mathrm{O}$ and 1-butanol $\mathrm{C}_{4} \mathrm{H}_{9} \mathrm{OH}$.

Experimental results ${ }^{132}$ indicate that the reaction temperature, presence of surfactant, and type of solvent affect the size of $\mathrm{Ag}_{2} \mathrm{~S}$ nanoparticles. Fig. 6 illustrates the influence of various conditions of synthesis on the formation of $\mathrm{Ag}_{2} \mathrm{~S}$ nanoparticles.

An improved hydrothermal/solvothermal method has been developed by Wang et al. ${ }^{133}$ to prepare nanostructured $\mathrm{Ag}_{2} \mathrm{~S}$. Using a liquid-solid-solution (LSS) system consisting of an ethanollinoleic acid liquid phase, solid metal linoleate, and a waterethanol solution under hydrothermal conditions, monodisperse $\mathrm{Ag}_{2} \mathrm{~S}$ nanocrystals of size $7.3 \mathrm{~nm}$ were successfully synthesized.

Biocompatible $\mathrm{Ag}_{2} \mathrm{~S}$ quantum dots were prepared through thermal decomposition of a single-source precursor, Ag-DDTC with $\mathrm{CH}_{3}\left(\mathrm{CH}_{2}\right)_{11} \mathrm{SH}$ as a covalent ligand and solvent. ${ }^{134}$ The reaction mixture was heated to $483 \mathrm{~K}$ at a heating rate of $15 \mathrm{~K} \mathrm{~min}^{-1}$ and kept for $1 \mathrm{~h}$ under a $\mathrm{N}_{2}$ atmosphere. As a result, hydrophobic $\mathrm{Ag}_{2} \mathrm{~S}$ quantum dots with an average diameter from 5.4 to $10.0 \mathrm{~nm}$ coated with $\mathrm{CH}_{3}\left(\mathrm{CH}_{2}\right)_{11} \mathrm{SH}$ as the surface ligand were obtained.

Stable and highly luminescent near-IR emitting $\mathrm{Ag}_{2} \mathrm{~S}$ colloidal quantum dots were prepared by a simple aqueous method using 2-mercaptopropionic acid $\left(\mathrm{C}_{3} \mathrm{H}_{6} \mathrm{O}_{2} \mathrm{~S} ; 2\right.$-MPA) as a coating. ${ }^{135}$ Nanoparticle size can be tuned between 2.3 and $3.1 \mathrm{~nm}$ with an emission maximum between 780 and $950 \mathrm{~nm}$.

A similar one-step method was reported by Jiang et al. ${ }^{56}$ using 3-mercaptopropionic acid (3-MPA) and EG rather than 2-MPA. In this case, the quantum dot surface was terminated with carboxyl groups. The PL emission wavelength of $\mathrm{Ag}_{2} \mathrm{~S}$ quantum dots was broadly tunable, from 510 to $1221 \mathrm{~nm}$, by varying the growth time. Li et al. ${ }^{57}$ demonstrated that $\mathrm{Ag}_{2} \mathrm{~S}$ quantum dots can be used as NIR luminescent probes for in vivo monitoring of lymphatic and vascular networks with deep penetration. They reported that $\mathrm{Ag}_{2} \mathrm{~S}$ quantum dots can provide spatial resolution of $40 \mu \mathrm{m}$ during in vivo photoluminescence (PL) imaging, and this allowed them to monitor angiogenesis.

\subsection{Hydrochemical deposition of different forms of nanostructured $\mathrm{Ag}_{2} \mathrm{~S}$}

Chemical deposition from aqueous solutions (also termed "chemical condensation method", and one-pot synthesis in 


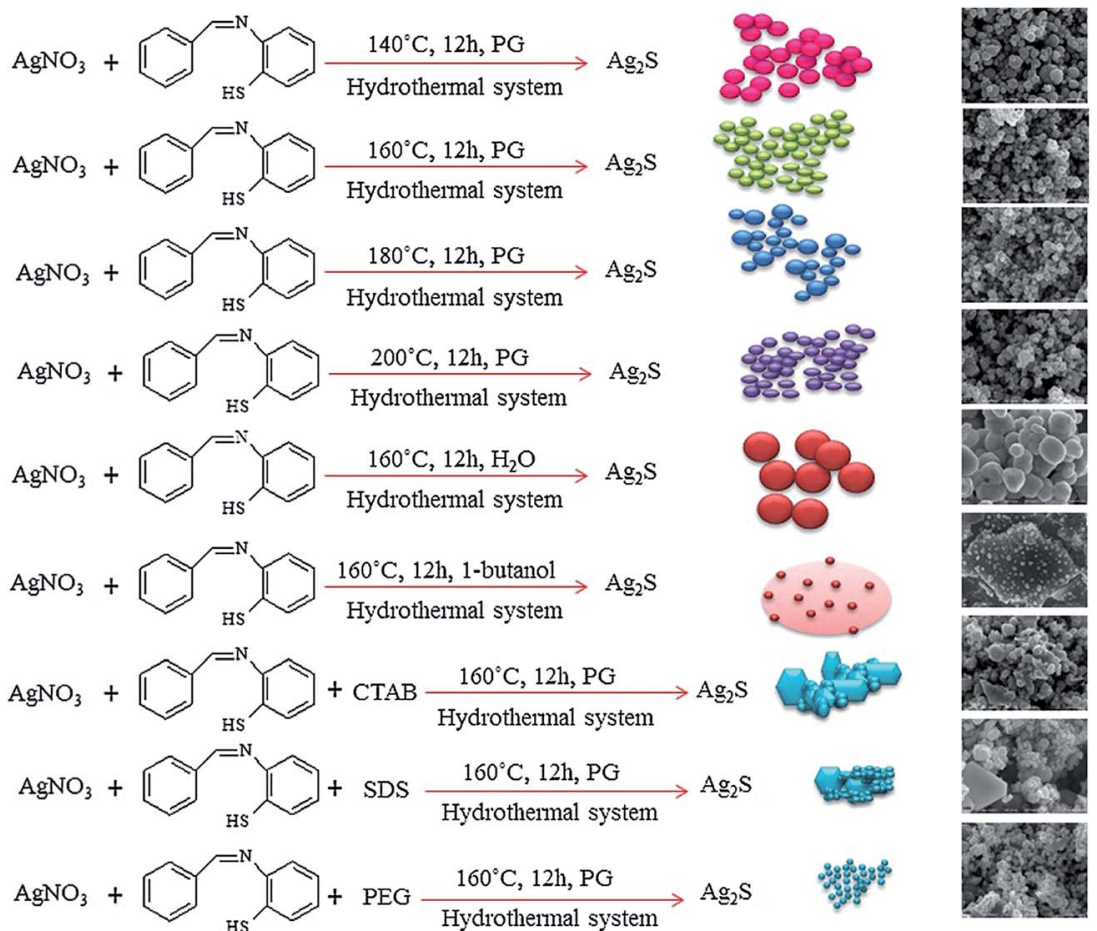

Fig. 6 Formation of $\mathrm{Ag}_{2} \mathrm{~S}$ nanoparticles at various conditions (schematic) ( $P G$ is propylene glycol $\left(\mathrm{C}_{3} \mathrm{H}_{8} \mathrm{O}_{2}\right), \mathrm{CTAB}$ is cetyltrimethyl ammonium bromide $\left(\mathrm{C}_{19} \mathrm{H}_{42} \mathrm{BrN}\right)$, SDS is sodium dodecyl sulfate $\left(\mathrm{C}_{12} \mathrm{H}_{25} \mathrm{SO}_{4} \mathrm{Na}\right)$ and $\mathrm{PEG}$ is polyethylene glycol $\left.20000 \mathrm{C}_{2 n} \mathrm{H}_{4 n+2} \mathrm{O}_{n+1}\right)$. Reprinted from ref. 132 with permission from Elsevier.

aqueous solutions) and hydrochemical bath deposition are the most popular methods used for the synthesis of nanocrystalline sulfide powders.

Hydrochemical bath deposition is a well-known method which allows preparation of colloidal solutions of $\mathrm{Ag}_{2} \mathrm{~S}$ nanoparticles and quantum dots, nanocrystalline and coarsecrystalline $\mathrm{Ag}_{2} \mathrm{~S}$ powders, isolated $\mathrm{Ag}_{2} \mathrm{~S}$ nanoparticles, and different heteronanostructures with $\mathrm{Ag}_{2} \mathrm{~S}$.

Usually, nanostructured $\mathrm{Ag}_{2} \mathrm{~S}$ synthesizes by hydrochemical deposition from aqueous solutions of $\mathrm{AgNO}_{3}$ and $\mathrm{Na}_{2} \mathrm{~S}$. Solutions of $\mathrm{Na}_{3} \mathrm{Cit}$ or the disodium salt of EDTA (Trilon B) are used as complexing agents. Coarse-crystalline $\mathrm{Ag}_{2} \mathrm{~S}$ powder is prepared by hydrothermal synthesis from an aqueous reaction mixture of $\mathrm{AgNO}_{3}, \mathrm{Na}_{2} \mathrm{~S}$ and $\mathrm{Na}_{3}$ Cit with subsequent heating of a matrix solution with the precipitated powder in a closed vessel at elevated temperature and pressure.

Hydrochemical deposition of $\mathrm{Ag}_{2} \mathrm{~S}$ nanopowders using of Trilon $\mathrm{B}$, and also hydrothermal synthesis of $\mathrm{Ag}_{2} \mathrm{~S}$ powder, are described in study. ${ }^{67}$

$\mathrm{Ag}_{2} \mathrm{~S}$ deposition in the presence of Trilon B occurs according to the following reaction scheme:

$$
2 \mathrm{AgNO}_{3}+\mathrm{Na}_{2} \mathrm{~S} \stackrel{\text { EDTA- } \mathrm{H}_{2} \mathrm{Na}_{2}}{\longrightarrow} \mathrm{Ag}_{2} \mathrm{~S} \downarrow+2 \mathrm{NaNO}_{3} .
$$

Trilon $\mathrm{B}$ was added with constant stirring to $\mathrm{AgNO}_{3}$ solution, and the prepared solution was then mixed with $\mathrm{Na}_{2} \mathrm{~S}$ solution. During mixing of the solutions, a sulfide formation reaction occurred instantaneously. All nanoparticles were deposited during 2 days. The average size $\mathrm{D}$ of $\mathrm{Ag}_{2} \mathrm{~S}$ nanoparticles in the deposited $\mathrm{Ag}_{2} \mathrm{~S}$ nanopowders was $58 \pm 8 \mathrm{~nm}$.

Disadvantages of the chemical deposition of $\mathrm{Ag}_{2} \mathrm{~S}$ from aqueous $\mathrm{AgNO}_{3}, \mathrm{Na}_{2} \mathrm{~S}$, and Trilon $\mathrm{B}$ solutions are the large size of prepared $\mathrm{Ag}_{2} \mathrm{~S}$ nanoparticles and the presence of a considerable amount of metallic Ag impurity.

Hydrochemical bath deposition using $\mathrm{Na}_{3} \mathrm{Cit}$ is a wellknown, simple and reliable universal "green" method which allows preparation of non-toxic colloidal solutions of $\mathrm{Ag}_{2} \mathrm{~S}$ nanoparticles, isolated $\mathrm{Ag}_{2} \mathrm{~S}$ nanoparticles and quantum dots with protective shells, $\mathrm{Ag}_{2} \mathrm{~S} / \mathrm{Ag}$ heteronanostructures, nanocrystalline and coarse-crystalline powders of $\mathrm{Ag}_{2} \mathrm{~S}^{76,136-139} \mathrm{~A}$ weak aqueous solution of $\mathrm{AgNO}_{3}$, which is widely applied in pharmacology and medicine and possesses antibacterial action, is usually used as a source of $\mathrm{Ag}^{+}$for $\mathrm{Ag}_{2} \mathrm{~S}$ synthesis. Conditions of hydrochemical bath deposition for preparing different forms of nanostructured $\mathrm{Ag}_{2} \mathrm{~S}$, and the previously unknown possibilities of this method are generalized in study. ${ }^{136}$

Hydrochemical deposition of nanostructured $\mathrm{Ag}_{2} \mathrm{~S}$ with using $\mathrm{Na}_{3} \mathrm{Cit}$ is an example of green chemistry because of the design of chemical products and processes that reduce or eliminate the use and generation of hazardous substances. ${ }^{140}$ Indeed, hydrochemical bath deposition allows one to obtain valuable products from harmless substances using environmentally friendly methods.

In study, ${ }^{136}$ different forms of nanostructured $\mathrm{Ag}_{2} \mathrm{~S}$ was synthesized by hydrochemical bath deposition from aqueous solutions of $\mathrm{AgNO}_{3}$ and $\mathrm{Na}_{2} \mathrm{~S}$ used as sources of $\mathrm{Ag}^{+}$and $\mathrm{S}^{2-}$. 
$\mathrm{Na}_{3}$ Cit was used as a complexing agent and electrostatic stabilizer.

The solubility product $\left(K_{\mathrm{sp}}\right)$ of $\mathrm{Ag}_{2} \mathrm{~S}$ is very small (according to, ${ }^{141}$ at $298 \mathrm{~K}, K_{\mathrm{sp}}=6.3 \times 10^{-50}$ ), and $\mathrm{Ag}_{2} \mathrm{~S}$ is formed from an aqueous solution of $\mathrm{AgNO}_{3}$ and $\mathrm{Na}_{2} \mathrm{~S}$ in a simple reaction

$$
2 \mathrm{AgNO}_{3}+\mathrm{Na}_{2} \mathrm{~S}=\mathrm{Ag}_{2} \mathrm{~S} \downarrow+2 \mathrm{NaNO}_{3},
$$

where concentrations of $\mathrm{S}^{2-}$ and $\mathrm{Ag}^{+}$are related by $C_{\mathrm{S}^{2-}}=C_{\mathrm{Ag}^{+}} / 2$. Small variation in the ratio of reagent concentrations as compared with the perfect reaction (4), introduction of a complexing agent, and control over synthetic conditions allow preparation of different forms of $\mathrm{Ag}_{2} \mathrm{~S}$ - from coarse-crystalline powder to colloidal nanoparticles.

A generalized scheme of synthesis of different types of nanostructured $\mathrm{Ag}_{2} \mathrm{~S}$ and $\mathrm{Ag}_{2} \mathrm{~S} / \mathrm{Ag}$ heteronanostructures is shown in Fig. 7.

Coarse-crystalline $\mathrm{Ag}_{2} \mathrm{~S}$ powders are deposited almost instantly from an aqueous solution of $\mathrm{AgNO}_{3}$ and $\mathrm{Na}_{2} \mathrm{~S}$ with a large excess concentration of $\mathrm{S}^{2-}\left(C_{\mathrm{S}^{2-}} \geq C_{\mathrm{Ag}^{+}}\right)$both without and with addition of $\mathrm{Na}_{3} \mathrm{Cit}$ as a complexing agent at room temperature in the dark (Fig. 7a). Synthesis with excess $\mathrm{Na}_{2} \mathrm{~S}$ and without addition of $\mathrm{Na}_{3}$ Cit led to the deposition of $\mathrm{Ag}_{2} \mathrm{~S}$ powder of particle size $\sim 1000 \mathrm{~nm}$. When $\mathrm{Na}_{3} \mathrm{Cit}$ was added to reaction mixtures having excess $\mathrm{Na}_{2} \mathrm{~S}$, the average size of $\mathrm{Ag}_{2} \mathrm{~S}$ particles decreased to $\sim 200 \mathrm{~nm}$.

If the concentration of $\mathrm{S}^{2-}$ is sufficient or differs slightly from the concentration required for the chemical bonding, all $\mathrm{Ag}^{+}$(i.e. $C_{\mathrm{S}^{2-}} \approx C_{\mathrm{Ag}^{+}} / 2+\delta$ ), then addition of $\mathrm{Na}_{3}$ Cit to the solution promotes the formation of $\mathrm{Ag}_{2} \mathrm{~S}$ nanoparticles and quantum dots (Fig. 7b). Deposition of $\mathrm{Ag}_{2} \mathrm{~S}$ takes place in neutral medium at $\mathrm{pH} \approx 7$ by the following reaction scheme

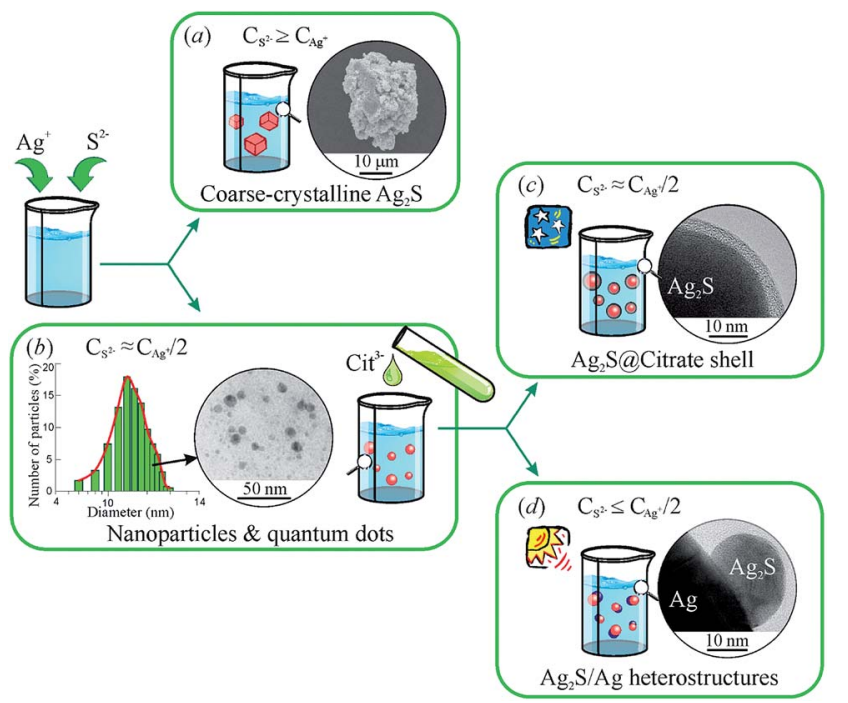

Fig. 7 Generalized scheme of the synthesis of various types of nanostructured $\mathrm{Ag}_{2} \mathrm{~S}$ and $\mathrm{Ag}_{2} \mathrm{~S} / \mathrm{Ag}$ heteronanostructures: (a) coarsecrystalline $\mathrm{Ag}_{2} \mathrm{~S}$; (b) $\mathrm{Ag}_{2} \mathrm{~S}$ quantum dots; (c) $\mathrm{Ag}_{2} \mathrm{SaC}$ core-shell nanoparticle with carbon-containing citrate shell; (d) $\mathrm{Ag}_{2} \mathrm{~S} / \mathrm{Ag}$ heteronanostructures. Reproduced from ref. 136 with permission from Wiley.
$2 \mathrm{AgNO}_{3}+(1 \pm \delta) \mathrm{Na}_{2} \mathrm{~S} \longrightarrow \mathrm{Na}_{3} \mathrm{C}_{6} \mathrm{H}_{5} \mathrm{O}_{7} \longrightarrow \mathrm{Ag}_{2} \mathrm{~S} \downarrow+2 \mathrm{NaNO}_{3}$

where $\delta \geq 0$. Some excess of $\mathrm{Na}_{2} \mathrm{~S}$ is necessary for synthesis of $\mathrm{Ag}_{2} \mathrm{~S}$ without an impurity of metallic $\mathrm{Ag}$ nanoparticles. Synthesis was carried out in a dark room.

$\mathrm{Na}_{3} \mathrm{Cit}$ has a triple role in aqueous solutions of $\mathrm{AgNO}_{3}$ and $\mathrm{Na}_{2} \mathrm{~S}$.

First, it is a complexing and stabilizing agent during deposition of $\mathrm{Ag}_{2} \mathrm{~S}$ nanoparticles, which occurs both in the light and dark (Fig. 7b). Second, during deposition in the dark, $\mathrm{Na}_{3} \mathrm{Cit}$ is adsorbed on $\mathrm{Ag}_{2} \mathrm{~S}$ nanoparticles, impeding their agglomeration. In this case, an increased duration of deposition and use of reaction mixtures with an enhanced concentration of $\mathrm{Na}_{3} \mathrm{Cit}$ leads to the formation of a protective citrate shell on the surface of $\mathrm{Ag}_{2} \mathrm{~S}$ nanoparticles (Fig. 7c). Third, during deposition in the light in aqueous solutions with lowered content of $\mathrm{S}^{2-}, \mathrm{Na}_{3} \mathrm{Cit}$ can reduce $\mathrm{Ag}^{+}$to metallic silver. ${ }^{\mathbf{1 4 2}}$

During deposition in the light, $\mathrm{Na}_{3} \mathrm{Cit}$, as a reducing agent, takes part in a photochemical reaction

$$
\mathrm{C}_{6} \mathrm{H}_{5} \mathrm{O}_{7}{ }^{3-}+2 \mathrm{Ag}^{+} \stackrel{h v}{\longrightarrow} \mathrm{C}_{5} \mathrm{H}_{4} \mathrm{O}_{5}{ }^{2-}+\mathrm{CO}_{2}+\mathrm{H}^{+}+2 \mathrm{Ag} \downarrow,
$$

in which citrate ions $\left(\mathrm{C}_{6} \mathrm{H}_{5} \mathrm{O}_{7}{ }^{3-}\right)$ reduce the $\mathrm{Ag}^{+}$present in the solution to metallic $\mathrm{Ag}$ nanoparticles and transform $\left(\mathrm{C}_{6} \mathrm{H}_{5} \mathrm{O}_{7}{ }^{3-}\right)$ to acetone-1,3-dicarboxylate ions $\left(\mathrm{C}_{5} \mathrm{H}_{4} \mathrm{O}_{5}{ }^{2-}\right)$. In this case, selection of the concentrations of $\mathrm{AgNO}_{3}, \mathrm{Na}_{2} \mathrm{~S}$, and $\mathrm{Na}_{3} \mathrm{Cit}$ in the initial solution meeting the condition $C_{\mathrm{S}^{2-}} \leq C_{\mathrm{Ag}^{+}} / 2$ makes it possible to deposit $\mathrm{Ag}$ nanoparticles along with $\mathrm{Ag}_{2} \mathrm{~S}$ nanoparticles and to synthesize $\mathrm{Ag}_{2} \mathrm{~S} / \mathrm{Ag}$ heteronanostructures (Fig. 7d).

In principle, citric acid (harmless standardized food additive E330) can be used as a complexing agent for $\mathrm{Ag}^{+}$, but its application in $\mathrm{Ag}_{2} \mathrm{~S}$ synthesis displaces the equilibrium into the acidic region, which is not desirable.

Nanosized $\mathrm{Ag}_{2} \mathrm{~S}$ powders were prepared from aqueous solutions of $\mathrm{AgNO}_{3}$ and $\mathrm{Na}_{2} \mathrm{~S}$ containing $\mathrm{Na}_{3}$ Cit. The concentration of $\mathrm{AgNO}_{3}$ was $50 \mathrm{mmol} \mathrm{l}^{-1}$. The concentration of $\mathrm{Na}_{2} \mathrm{~S}$ in the initial reaction mixtures was slightly over half of the $\mathrm{AgNO}_{3}$ concentration, i.e., $C_{\mathrm{Na}_{2} \mathrm{~S}}=\left(C_{\mathrm{AgNO}_{3}} / 2\right)+\delta$ with $\delta=0.5 \mathrm{mmol} \mathrm{l}^{-1} .^{136}$ The average particle size $(D)$ in the examined $\mathrm{Ag}_{2} \mathrm{~S}$ nanopowders was about $46 \pm 7 \mathrm{~nm}$.

The technology for the production of $\mathrm{Ag}_{2} \mathrm{~S}$ nanopowders with preset nanoparticle size from 20 to $500 \mathrm{~nm}$ by hydrochemical deposition has been patented. ${ }^{\mathbf{1 4 3}}$

Stable colloidal solutions of $\mathrm{Ag}_{2} \mathrm{~S}$ quantum dots were prepared from the reaction mixtures with $\mathrm{AgNO}_{3}$ concentrations $\left(C_{\mathrm{AgNO}_{3}}\right)$ from 0.3125 to $2.5 \mathrm{mmol} \mathrm{l}^{-1}$. The $\mathrm{Na}_{2} \mathrm{~S}$ concentration $\left(C_{\mathrm{Na}_{2} \mathrm{~S}}\right)$ in the reaction mixtures was slightly over half of the $\mathrm{AgNO}_{3}$ concentration (i.e., $C_{\mathrm{Na}_{2} \mathrm{~s}}=\left(C_{\mathrm{AgNO}_{3}} / 2\right)+\delta$, where $\left.\delta=0.01 \mathrm{mmol} \mathrm{l}^{-1}\right) .{ }^{136}$

According to the dynamic light scattering (DLS) data, the size of $\mathrm{Ag}_{2} \mathrm{~S}$ quantum dots in colloidal solutions was $\leq 20 \mathrm{~nm}$. The DLS zeta-potential measurements of colloidal solutions confirmed that these solutions remained stable for $>100$ days. The particle size distributions for the colloidal solutions with different size of $\mathrm{Ag}_{2} \mathrm{~S}$ quantum dots and the appearance of these colloidal solutions are shown in Fig. 8a and b. 
The zeta potential ( $\zeta$ ) of quantum dots in a solution is an indicator of the system stability. The DLS measurements revealed that 3 days after synthesis, the $\zeta$ was -45 to $-28 \mathrm{mV}$, and the quantum dot size was $2-13 \mathrm{~nm}$. The $\zeta$ and size of $\mathrm{Ag}_{2} \mathrm{~S}$ quantum dots measured 100 days after synthesis of colloidal solutions remained almost unchanged. ${ }^{136}$ The comparison of the $\zeta$ with the average size ( $\left.D_{\text {DLS }}\right)$ of quantum dots for synthesized colloidal solutions 100 days after synthesis is displayed in Fig. 8c. The $D_{\text {DLS }}$ of quantum dots was 2 to $17 \mathrm{~nm}$, the value of $\zeta$ varied from -49 to $-29 \mathrm{mV}$, and the average $\zeta$ was $-35 \pm$ $10 \mathrm{mV}$. It can be seen that, the smaller is the absolute value of $\zeta$, the larger is the size of $\mathrm{Ag}_{2} \mathrm{~S}$ quantum dots.

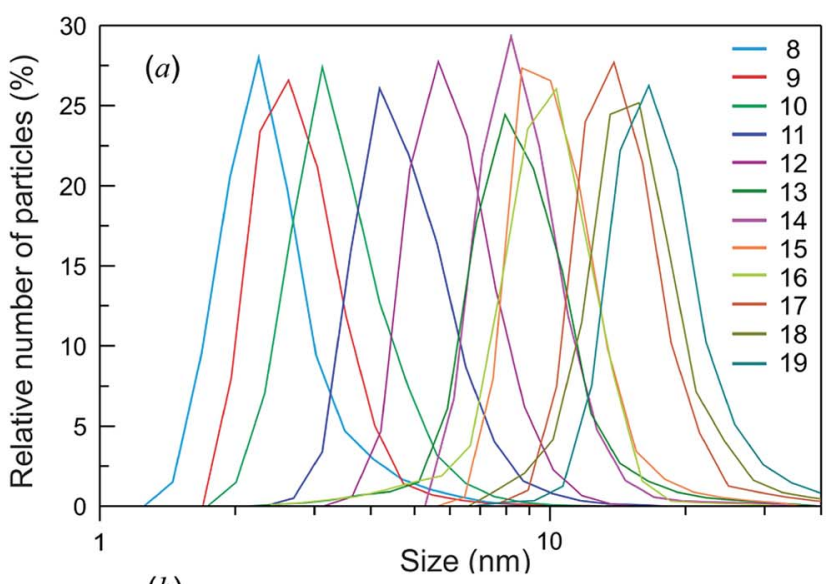

(b)
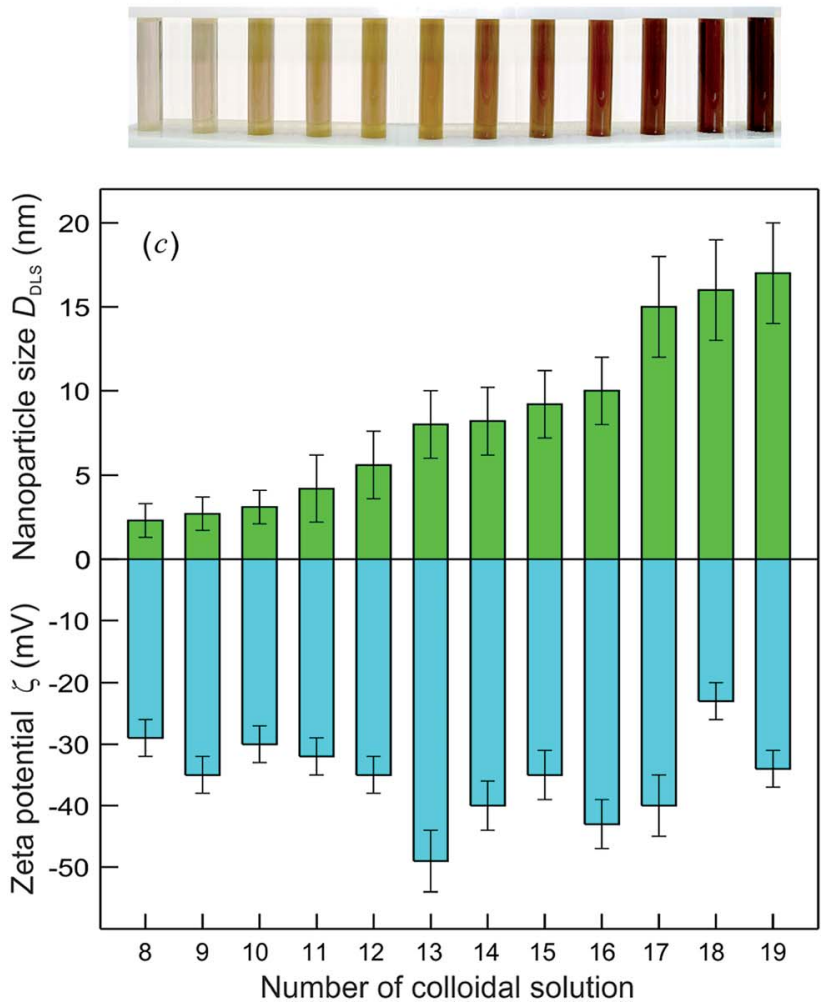

Fig. 8 (a) The particle size distributions measured by DLS for colloidal solutions with different average sizes of $\mathrm{Ag}_{2} \mathrm{~S}$ QDs from 2.3 to $17.0 \mathrm{~nm}$, (b) the appearance of these colloidal solutions, and (c) the average size $D_{\text {DLS }}$ and zeta potential $\zeta$ of $\mathrm{Ag}_{2} \mathrm{~S}$ QDs in colloidal solutions measured 100 days after synthesis.
Fig. 9 presents the size-dependent PL emission spectra of $\mathrm{Ag}_{2} \mathrm{~S}$ colloidal solutions in which the fluorescence of $\mathrm{Ag}_{2} \mathrm{~S}$ quantum dots is tunable from $\sim 1176$ to $\sim 960 \mathrm{~nm}$ by decreasing the nanoparticle $D_{\text {DLS }}$ from 15.0 to $2.3 \mathrm{~nm}$. According to, ${ }^{56}$ the PL peak for $\mathrm{Ag}_{2} \mathrm{~S}$ quantum dots with a size about $1.5 \mathrm{~nm}$ was observed at $\sim 640 \mathrm{~nm}$ (see Fig. 9). The PL emission peaks shifted from $\sim 960$ to $\sim 1170 \mathrm{~nm}$ with the size of $\mathrm{Ag}_{2} \mathrm{~S}$ quantum dots increasing from $\sim 2.3$ to $4.2 \mathrm{~nm}$ and remained constant at $1166-$ $1176 \mathrm{~nm}$ with an increase of the quantum dot size from $\sim 4.2$ to $>15 \mathrm{~nm}$. The continuous blue shift of the PL emission of $\mathrm{Ag}_{2} \mathrm{~S}$ quantum dots from $\sim 1176$ to $\sim 640 \mathrm{~nm}$ can be attributed to the strengthened quantum confinement effect and increase in band gap $E_{\mathrm{g}}$ which resulted from the decreasing size of $\mathrm{Ag}_{2} \mathrm{~S}$ quantum dots. This hypothesis is in agreement with experimental data ${ }^{144}$ on the size-dependent band gap of $\mathrm{Ag}_{2} \mathrm{~S}$ nanopowders. An almost constant position of the PL emission peaks at $\sim 1166$ to $1176 \mathrm{~nm}$ for the $\mathrm{Ag}_{2} \mathrm{~S}$ quantum dots with a boundary value of $\geq 4.2 \mathrm{~nm}$ is evidence for transition from the strong quantum confinement regime to a weak quantum confinement regime. According to this hypothesis, the estimated $\mathrm{Ag}_{2} \mathrm{~S}$ exciton radius $\left(R_{\text {exc }}\right)$ is less than half of boundary size of $4.2 \mathrm{~nm}$ (i.e., $\leq 2.1 \mathrm{~nm}$ ).

The $R_{\text {exc }}$ for $\mathrm{Ag}_{2} \mathrm{~S}$, which is calculated by formula (1), is about $1.4 \pm 0.1 \mathrm{~nm}$, and the exciton diameter is about $3 \mathrm{~nm}$. According to an analogous estimation, ${ }^{145}$ the $\mathrm{Ag}_{2} \mathrm{~S}$ exciton diameter ranges from 3.0 to $4.4 \mathrm{~nm}$. A strong blue shift for a quantum dot of size $1.5 \mathrm{~nm}$ agrees with data ${ }^{145}$ on the $\mathrm{Ag}_{2} \mathrm{~S}$ exciton diameter. $\mathrm{An}$ estimated exciton diameter $\sim 3 \mathrm{~nm}$ for $\mathrm{Ag}_{2} \mathrm{~S}$ is in satisfactory agreement with the experimental result $(4.2 \mathrm{~nm}){ }^{136}$ which follows from the size-dependent PL emission spectra (see Fig. 9).

The technology for preparing aqueous colloidal solutions of stable $\mathrm{Ag}_{2} \mathrm{~S}$ quantum dots has been patented. ${ }^{146}$

$\mathrm{Ag}_{2} \mathrm{~S} @ \mathrm{C}$ nanoparticles with a carbon-containing citrate shell were found in colloidal solutions prepared from an aqueous solutions of $\mathrm{AgNO}_{3}$ and $\mathrm{Na}_{2} \mathrm{~S}$ at concentrations of 5.0 and

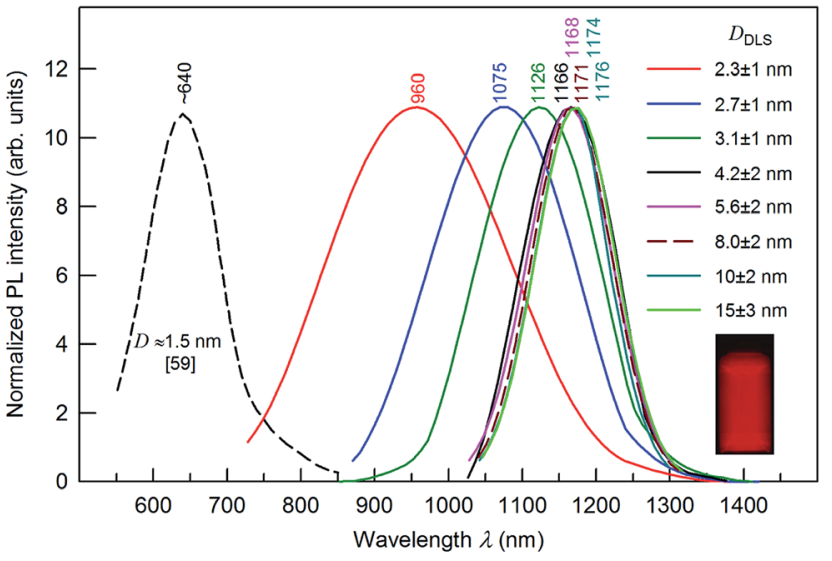

Fig. 9 The size-dependent $\mathrm{PL}$ emission spectra of $\mathrm{Ag}_{2} \mathrm{~S}$ colloidal solutions with quantum dot size $D_{\mathrm{DLS}}$ from 2.3 to $15.0 \mathrm{~nm}$ under an excitation of $658 \mathrm{~nm}$. For comparison, the dashed line shows the position of the $\mathrm{PL}$ emission peak for $\mathrm{Ag}_{2} \mathrm{~S}$ quantum dots of size $\sim 1.5 \mathrm{~nm} .{ }^{56}$ The wavelengths corresponding to the maxima of the PL peaks are indicated. The inset presents a fluorescence image of $\mathrm{Ag}_{2} \mathrm{~S}$ colloidal solution of quantum dot size $\sim 8 \mathrm{~nm}$. 
$2.5 \mathrm{mmol} \mathrm{l}^{-1}$ or 50 and $25 \mathrm{mmol} \mathrm{l} \mathrm{l}^{-1}$, respectively; the $\mathrm{Na}_{3} \mathrm{Cit}$ concentration varied from 5 to $100 \mathrm{mmol} \mathrm{l}^{-1} \cdot{ }^{\mathbf{6 8 , 1 3 6 , 1 4 7}}$ Synthesis was carried out at room temperature in the dark.

The X-ray diffraction (XRD) patterns of $\mathrm{Ag}_{2} \mathrm{~S}$ nanopowders deposited from a reaction mixture of $\mathrm{AgNO}_{3}, \mathrm{Na}_{2} \mathrm{~S}$ and $\mathrm{Na}_{3} \mathrm{Cit}$ with concentrations of 5.0, 2.5 and $5.0 \mathrm{mmol} \mathrm{l}^{-1}$, respectively, are shown in Fig. 10A. These nanopowders can be distinguished by their dwell time in the solution (from 20 to $1200 \mathrm{~min}$ ). The quantitative analysis of the XRD patterns and comparison with data $^{\mathbf{1 4 8}}$ have shown that the observed set of diffraction reflections corresponds to nonstoichiometric monoclinic (space group $P 2_{1} / c$ ) acanthite $\sim \mathrm{Ag}_{1.93} \mathrm{~S}$. The amorphous carboncontaining shell is not visible on the XRD patterns.

The $\mathrm{Ag}_{2} \mathrm{~S}$ nanoparticles extracted from the colloidal solutions have an amorphous shell (Fig. 10B). Other things being equal, the thickness of the shell grows when the nanoparticle dwell time in the colloidal solution containing $\mathrm{C}_{6} \mathrm{H}_{5} \mathrm{O}_{7}{ }^{3-}$ (Fig. 10B(a)-(d)) increases, and when the concentration of $\mathrm{Na}_{3} \mathrm{Cit}$ in the solution increases. A filtered image of area 1 isolated by a white square is shown in Fig. $10 \mathrm{~B}(\mathrm{a})$. The determination of the interplanar distances of cores confirmed a monoclinic structure of the colloidal $\mathrm{Ag}_{2} \mathrm{~S}$ nanoparticles. Fig. 10C(e) shows as an example of the XRD pattern of the core of the nanoparticle presented in Fig. 10B(a). The observed set of spots $(-1-11),(-111),(020)$, and $(-212)$ corresponds to the [101] plane of the reciprocal lattice of the monoclinic (space group $\left.P 2_{1} / c\right) \alpha-\mathrm{Ag}_{2} \mathrm{~S}$ phase with an acanthite structure.

According to the energy-dispersive X-ray spectroscopy (EDX) results, the content of $\mathrm{Ag}$ and $\mathrm{S}$ in the colloidal core-shell nanoparticles corresponds to $\mathrm{Ag}_{1.95-1.98} \mathrm{~S}$ (Fig. $\left.10 \mathrm{C}(\mathrm{f})-(\mathrm{h})\right)$. The content of carbon is proportional to the intensity of the $\mathrm{C} \mathrm{K} \alpha$ line and increases with growth of the shell thickness (Fig. 10C(f)-(h)). Hence, the shell of sulfide nanoparticles contains carbon and is a citrate shell.

Indeed, the three carboxylate groups of $\mathrm{Na}_{3} \mathrm{Cit}$ have strong affinity for $\mathrm{Ag}^{+}$, which favors the attachment of citrate groups on the surface of the $\mathrm{Ag}_{2} \mathrm{~S}$ nanoparticles and prevents them from aggregating into large particles. In other words, $\mathrm{C}_{6} \mathrm{H}_{5} \mathrm{O}_{7}{ }^{3-}$ are adsorbed on the surface of nanoparticles and form a citrate carbon-containing shell that prevents the growth and agglomeration of the nanoparticles.

In the solutions with $\mathrm{Na}_{3} \mathrm{Cit}$, the $\mathrm{C}_{6} \mathrm{H}_{5} \mathrm{O}_{7}{ }^{3-}$ are adsorbed on the surface of $\mathrm{Ag}_{2} \mathrm{~S}$ nanoparticles and first form an uneven, discontinuous shell. As the $\mathrm{Ag}_{2} \mathrm{~S}$ nanoparticle dwell time in the solution increases, the discontinuities are gradually filled with citrate complexes, and a continuous carbon-containing shell is formed. Gradual adsorption of the citrate complexes by the formed coating promotes smoothing of the shell surface and the growth of the shell thickness. ${ }^{68,136} \mathrm{~A}$ continuous shell is formed when $C_{\mathrm{S}^{2-}}=C_{\mathrm{Ag}^{+}} / 2$ and $C_{\mathrm{Ag}^{+}} / 4 \leq C_{\mathrm{Cit}^{3-}} \leq C_{\mathrm{Ag}^{+}}$.

The presence of a protective citrate shell is important for the PL of $\mathrm{Ag}_{2} \mathrm{~S}$ nanoparticles. A decrease in nanoparticle size should be accompanied by a blue shift of the PL peak. However, the observed shift may be less than expected because of the formation of surface trap states in the band gap and electron-phonon coupling. To induce a blue shift, one should suppress the formation of surface trap states in the band gap of $\mathrm{Ag}_{2} \mathrm{~S}$ nanoparticles. If the core size is constant, a growth of the protective

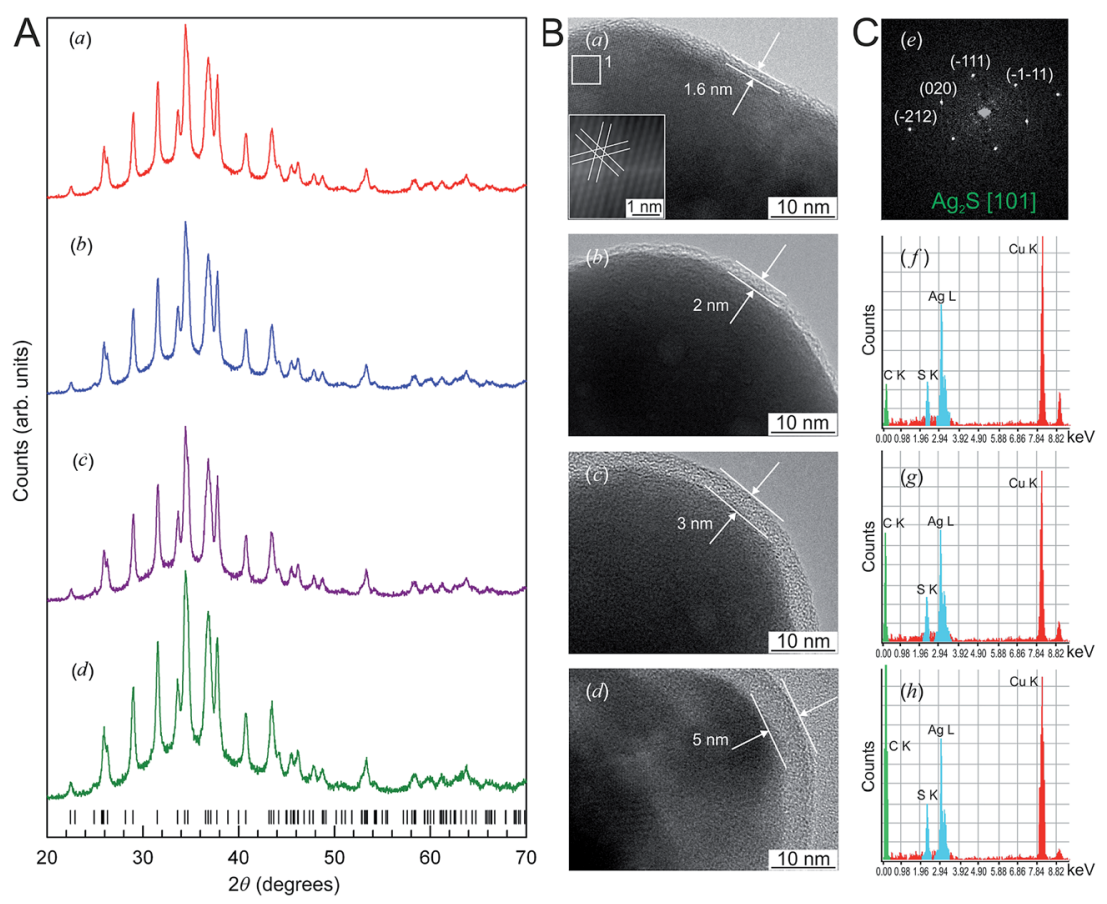

Fig. 10 (A) The XRD patterns of monoclinic (space group $P 2_{1} / C$ ) $\mathrm{Ag}_{2} \mathrm{~S}$ nanoparticles and (B) HRTEM images of silver sulfide nanoparticles and the growth of the carbon-containing citrate shell thickness as a function of the nanoparticle dwell time in the solution: (a) 20 min, (b) 40 min, (c) $420 \mathrm{~min}$, (d) $1200 \mathrm{~min}$. Vertical marks on XRD patterns indicate the positions of diffraction reflections of the nonstoichiometric monoclinic $\alpha$ $\mathrm{Ag}_{1.93} \mathrm{~S}$ phase. (C) (e) Selected area of electron diffraction (SAED obtained from the area 1 of HRTEM nanoparticle (a); ( $\left.\mathrm{f}\right),(\mathrm{g})$, and (h) cumulative elemental EDX patterns of nanoparticles (b), (c), and (d), respectively). Reproduced from ref. 136 with permission from Wiley. 
carbon-containing citrate shell thickness leads to weak intensity enhancement of the PL peaks and a small shift of peaks into the region of lower wavelength (Fig. 11). The position of PL peaks does not depend on the size of an $\mathrm{Ag}_{2} \mathrm{~S}$ core of $\geq 12 \mathrm{~nm}$.

According to, ${ }^{68,136,147}$ hydrochemical bath deposition allows preparation of $\mathrm{Ag}_{2} \mathrm{~S} @ \mathrm{C}$ core-shell nanoparticles with pre-assigned sizes of the $\mathrm{Ag}_{2} \mathrm{~S}$ core from 10 and $50 \mathrm{~nm}$ and pre-assigned carboncontaining citrate shell thickness from 1.5 to $10 \mathrm{~nm}$.

The process of manufacture of $\mathrm{Ag}_{2} \mathrm{~S} @ \mathrm{C}$ core-shell nanoparticles with a protective citrate carbon-containing shell by hydrochemical deposition has been patented. ${ }^{\mathbf{1 4 9}}$

Comparison of advantages and disadvantages of the main methods for synthesis of different forms of nanostructured $\mathrm{Ag}_{2} \mathrm{~S}$ is presented in summary Table 1 .

From a comparison of different methods for the synthesis of nanostructured $\mathrm{Ag}_{2} \mathrm{~S}$, it follows that the most universal method is hydrochemical deposition. This method allows synthesis of colloidal solutions of $\mathrm{Ag}_{2} \mathrm{~S}$ nanoparticles, isolated $\mathrm{Ag}_{2} \mathrm{~S}$ nanoparticles and quantum dots with protective shells, $\mathrm{Ag}_{2} \mathrm{~S} / \mathrm{Ag}$ heteronanostructures, nanocrystalline and coarse-crystalline powders of $\mathrm{Ag}_{2} \mathrm{~S}$. All the forms of nanostructured $\mathrm{Ag}_{2} \mathrm{~S}$ with controllable size can be prepared from the same chemical reagents by varying only their concentrations in solution and the conditions of synthesis. The important advantage of hydrochemical deposition in comparison with other methods is the reproducibility of obtained results.

Hydrothermal and solvothermal synthetic methods are most promising for the preparation of $\mathrm{Ag}_{2} \mathrm{~S}$ in the form of sufficiently large objects with different morphologies (e.g., leaf-like nanosheets, flake or star-shaped crystallites, faceted crystals, tetrahedral and hexagonal particles, hollow particles, etc.). Such objects can have the size from hundreds of nanometers to tens of micrometers.

The preferred method for preparation of $\mathrm{Ag}_{2} \mathrm{~S}$ nanowires with a high aspect ratio (length/diameter) is template synthesis using silver foil or an aluminum oxide template.

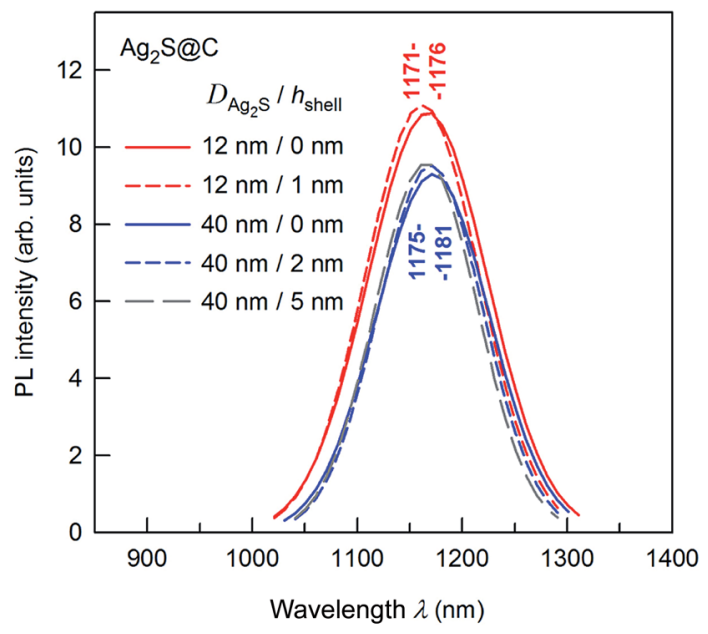

Fig. 11 Effect of citrate shell thickness on the PL emission spectra of $\mathrm{Ag}_{2} \mathrm{~S} @ \mathrm{CC}$ core-shell nanoparticles. The wavelengths corresponding to the maxima of the PL peaks are indicated. The wavelength of excitation is $658 \mathrm{~nm}$.

\section{Crystal structure of $\mathrm{Ag}_{2} \mathrm{~S}$ phases}

$\mathrm{Ag}_{2} \mathrm{~S}$ has three basic polymorphic modifications: monoclinic $\alpha$ $\mathrm{Ag}_{2} \mathrm{~S}$ acanthite, cubic $\beta-\mathrm{Ag}_{2} \mathrm{~S}$ argentite, and high-temperature cubic $\gamma-\mathrm{Ag}_{2} \mathrm{~S}$ sulfide. Structures of the different phases of $\mathrm{Ag}_{2} \mathrm{~S}$ were defined originally in studies ${ }^{\mathbf{1 5 0 - 1 5 2}}$ and specified later in works. ${ }^{153-155}$ In works, ${ }^{150-153}$ the structure of different $\mathrm{Ag}_{2} \mathrm{~S}$ phases was determined on samples of natural minerals such as acanthite and also pseudomorphic acanthite that preserved the cubic morphology of argentite. In works, ${ }^{154,155}$ an artificial crystal or a powder of $\mathrm{Ag}_{2} \mathrm{~S}$ were used for structure determination. In all cases, these were coarse-grained samples with grain (particle) size of 5-10 $\mu \mathrm{m}$ or larger.

Crystal structures of these phases are fairly complex. Hence, in most experimental works devoted to synthesis and properties of $\mathrm{Ag}_{2} \mathrm{~S}$, description of the crystal structure of the synthesized sulfide is lacking ${ }^{57,156,157}$ or it is made by comparing experimental XRD or TEM results ${ }^{46,49,56,57,70,73,100,117,158-160}$ with old XRD data. ${ }^{150}$ So, in studies, ${ }^{\mathbf{4 6 , 4 9 , 1 5 9 - 1 6 1}}$ without performing full-profile structure refinement, it was suggested that $\mathrm{Ag}_{2} \mathrm{~S}$ synthesized in the form of a film, nanocrystalline powder or nanoparticles has a crystal structure of natural acanthite, whereas in work ${ }^{75}$ it was assumed that synthesized $\mathrm{Ag}_{2} \mathrm{~S}$ film had the structure of argentite. However, the crystal structure of synthetic $\mathrm{Ag}_{2} \mathrm{~S}$ may have considerable differences that affect the properties of $\mathrm{Ag}_{2} \mathrm{~S}$. For example, with regard to the XRD patterns of $\mathrm{Ag}_{2} \mathrm{~S}$ nanoparticles, authors ${ }^{\mathbf{1 5 9}}$ found a set of spots corresponding to the monoclinic $\alpha-\mathrm{Ag}_{2} \mathrm{~S}$ phase with an acanthite structure, as well as several spots that could not be identified in a monoclinic acanthite-type structure. According to,${ }^{159}$ the atomic ratio of $\mathrm{Ag}$ to $S$ was estimated to be 1.7 and even 1.1 for nanoparticles with a size of $\sim 10$ and $\sim 6 \mathrm{~nm}$, respectively. In other words, the examined nanoparticles had the nonstoichiometric chemical composition $\mathrm{Ag}_{1.7} \mathrm{~S}$ and even $\mathrm{Ag}_{1.1} \mathrm{~S}$.

Careful determination of crystal structures of coarsecrystalline and nanocrystalline acanthite $\alpha-\mathrm{Ag}_{2} \mathrm{~S}$ and argentite $\beta-\mathrm{Ag}_{2} \mathrm{~S}$ has been performed recently in studies. ${ }^{118,148,162-166}$

\subsection{Artificial coarse-crystalline $\alpha-\mathrm{Ag}_{2} \mathrm{~S}$}

According to, ${ }^{150,153}$ the structure of acanthite $\alpha-\mathrm{Ag}_{2} \mathrm{~S}$ can be interpreted as a result of distortion of the $\beta-\mathrm{Ag}_{2} \mathrm{~S}$ argentite structure. Indeed, the unit cells of $\alpha-\mathrm{Ag}_{2} \mathrm{~S}$ acanthite proposed in studies ${ }^{150,153}$ have axes that can be represented as a combination of axes $a_{\mathrm{bcc}}, b_{\mathrm{bcc}}$ and $c_{\mathrm{bcc}}$ of the unit cell of bcc argentite.

Recently, ${ }^{118,163}$ the crystal structure of $\alpha-\mathrm{Ag}_{2} \mathrm{~S}$ acanthite was refined for the first time on synthesized artificial samples of coarse-crystalline powder of $\mathrm{Ag}_{2} \mathrm{~S}$ with the use of full-profile analyses of XRD data. The average particle size $D$ of coarsecrystalline $\mathrm{Ag}_{2} \mathrm{~S}$ powder was estimated from the value of specific surface area $S_{\mathrm{sp}}=1.6 \pm 0.1 \mathrm{~m}^{2} \mathrm{~g}^{-1}$ and was $\sim 515 \mathrm{~nm}$.

According to EDX results, the content of $\mathrm{Ag}$ and $\mathrm{S}$ in the synthesized coarse-crystalline $\mathrm{Ag}_{2} \mathrm{~S}$ powder was $86.8 \pm 0.4$ and $12.9 \pm 0.1 \mathrm{wt} \%$, which corresponds to stoichiometric $\mathrm{Ag}_{2} \mathrm{~S}$.

The refinement of the crystal structure of synthesized $\mathrm{Ag}_{2} \mathrm{~S}$ provided the following results: synthesized $\mathrm{Ag}_{2} \mathrm{~S}$ had a crystal structure of $\alpha-\mathrm{Ag}_{2} \mathrm{~S}$ acanthite type; monoclinic (space group 
Table 1 Methods of synthesis of different forms of nanostructured $A_{2} S$

\begin{tabular}{|c|c|c|c|c|c|}
\hline Method & Main reagents ${ }^{a}$ & $\begin{array}{l}\text { Forms of } \\
\text { nanostructured } \mathrm{Ag}_{2} \mathrm{~S}\end{array}$ & Advantages & Disadvantages & Ref. \\
\hline $\begin{array}{l}\text { Hydro-thermal } \\
\text { method }\end{array}$ & $\begin{array}{l}\mathrm{AgNO}_{3}, \mathrm{CS}_{2}, \\
\mathrm{Na}_{2} \mathrm{~S}, \mathrm{NH}_{4} \mathrm{OH}, \\
\left(\mathrm{NH}_{2}\right)_{2} \mathrm{CS}, \\
\mathrm{C}_{19} \mathrm{H}_{42} \mathrm{BrN}, \\
\mathrm{N}_{2} \mathrm{~S}_{2} \mathrm{O}_{3}, \mathrm{Ag} \\
{\left[\mathrm{S}_{2} \mathrm{P}(\mathrm{OR})_{2}\right](\mathrm{R}=} \\
\left.\mathrm{C}_{n} \mathrm{H}_{2 n+1}\right), \\
\mathrm{CH}_{3}\left(\mathrm{CH}_{2}\right)_{11} \mathrm{SH}, \\
\mathrm{PVP}\end{array}$ & $\begin{array}{l}\text { Leaf-like } \\
\text { nanosheets, faceted } \\
\text { and cubic } \\
\text { nanocrystals, hollow } \\
\text { nanohexagons, } \\
\text { tetrahedral and rice- } \\
\text { shaped } \\
\text { nanoparticles }\end{array}$ & $\begin{array}{l}\text { Large scale of } \\
\text { products }\end{array}$ & $\begin{array}{l}\text { Complicated process, } \\
\text { elaborate equipment, } \\
\text { non-uniform size } \\
\text { distribution, toxic } \\
\text { reagents }\end{array}$ & $\begin{array}{l}108,110, \\
111,113, \\
114 \text { and } 117\end{array}$ \\
\hline $\begin{array}{l}\text { Solvo-thermal } \\
\text { method }\end{array}$ & $\begin{array}{l}\mathrm{AgNO}_{3}, \mathrm{CS}_{2}, \\
\mathrm{NH}_{4} \mathrm{OH} \\
\mathrm{C}_{2} \mathrm{H}_{5} \mathrm{OH}, \mathrm{PVP}\end{array}$ & $\begin{array}{l}\text { Flake or star-shape } \\
\text { nanocrystallite }\end{array}$ & Low cost reagents & $\begin{array}{l}\text { Elaborate equipment, } \\
\text { large and non-uniform } \\
\text { size, toxic reagents }\end{array}$ & 107 \\
\hline $\begin{array}{l}\text { Solvo-thermal } \\
\text { method }\end{array}$ & $\begin{array}{l}\mathrm{AgNO}_{3} \\
\mathrm{C}_{13} \mathrm{H}_{11} \mathrm{NS} \\
\mathrm{C}_{19} \mathrm{H}_{42} \mathrm{BrN} \\
\mathrm{C}_{4} \mathrm{H}_{9} \mathrm{OH}\end{array}$ & $\begin{array}{l}\text { Spherical } \\
\text { nanoparticles }\end{array}$ & $\begin{array}{l}\text { Good re- } \\
\text { producibility }\end{array}$ & $\begin{array}{l}\text { Elaborate equipment, } \\
\text { non-uniform size }\end{array}$ & 132 \\
\hline $\begin{array}{l}\text { Solvo-thermal } \\
\text { method }\end{array}$ & $\begin{array}{l}\mathrm{C}_{18} \mathrm{H}_{31} \mathrm{AgO}_{2} \\
\mathrm{C}_{18} \mathrm{H}_{32} \mathrm{O}_{2} \\
\mathrm{C}_{2} \mathrm{H}_{5} \mathrm{OH}\end{array}$ & $\begin{array}{l}\text { Monodisperse } \\
\text { nanocrystals }\end{array}$ & $\begin{array}{l}\text { Small size, uniform } \\
\text { size distribution }\end{array}$ & Elaborate equipment & 133 \\
\hline $\begin{array}{l}\text { Hydro-chemical } \\
\text { deposition }\end{array}$ & $\begin{array}{l}\mathrm{AgNO}_{3}, \mathrm{NH}_{4} \mathrm{OH}, \\
\mathrm{Na}_{2} \mathrm{~S}_{2} \mathrm{O}_{3}, \\
\left(\mathrm{NH}_{2}\right)_{2} \mathrm{CS}\end{array}$ & $\begin{array}{l}\text { Rod-like } \\
\text { nanocrystals, } \\
\text { nanowires, worm- } \\
\text { like nanoparticles, } \\
\text { nano-polyhedrons }\end{array}$ & $\begin{array}{l}\text { Easy operation, high } \\
\text { yield, good re- } \\
\text { producibility }\end{array}$ & $\begin{array}{l}\text { Non-uniform size } \\
\text { distribution }\end{array}$ & 106 and 109 \\
\hline $\begin{array}{l}\text { Template } \\
\text { method }\end{array}$ & $\begin{array}{l}\mathrm{AgNO}_{3}, \mathrm{C}_{4} \mathrm{H}_{6} \mathrm{O}_{2}, \\
\left(\mathrm{NH}_{4}\right)_{2} \mathrm{~S}_{2} \mathrm{O}_{6}\left(\mathrm{O}_{2}\right), \\
n \text {-heptane, } \\
\mathrm{Na}_{2} \mathrm{~S}_{2} \mathrm{O}_{3}, \\
\mathrm{C}_{19} \mathrm{H}_{42} \mathrm{BrN}, \mathrm{CS}_{2}\end{array}$ & $\begin{array}{l}\text { Microsphere with } \\
\text { surface flower-like } \\
\text { structure, hollow } \\
\text { nanospheres }\end{array}$ & $\begin{array}{l}\text { Controllable size } \\
\text { and morphology }\end{array}$ & $\begin{array}{l}\text { Complicated sequential } \\
\text { process }\end{array}$ & 112 and 115 \\
\hline $\begin{array}{l}\text { Thermal } \\
\text { decomposition } \\
\text { (hot-injection } \\
\text { process) }\end{array}$ & $\begin{array}{l}\mathrm{C}_{7} \mathrm{H}_{5} \mathrm{AgOS} \\
\mathrm{C}_{24} \mathrm{H}_{51} \mathrm{P} \\
\left(\mathrm{C}_{2} \mathrm{H}_{5}\right)_{2} \mathrm{NCSSAg}, \\
\text { silver xanthate }\end{array}$ & $\begin{array}{l}\text { Cube-shaped and } \\
\text { spherical } \\
\text { nanocrystals }\end{array}$ & $\begin{array}{l}\text { Controllable size } \\
\text { and morphology, } \\
\text { simplicity, safety }\end{array}$ & $\begin{array}{l}\text { Elaborate equipment, } \\
\text { sequential process }\end{array}$ & $39,102-104$ \\
\hline Pyrolysis & $\begin{array}{l}\mathrm{AgNO}_{3}, \mathrm{~S} \\
\mathrm{C}_{18} \mathrm{H}_{35} \mathrm{NH}_{2}\end{array}$ & Nanoparticles & Uniform size & Low yield & 131 \\
\hline $\begin{array}{l}\text { Thermal } \\
\text { decomposition }\end{array}$ & $\begin{array}{l}\left(\mathrm{C}_{2} \mathrm{H}_{5}\right)_{2} \mathrm{NCS}_{2} \mathrm{Ag} \\
\mathrm{CH}_{3}\left(\mathrm{CH}_{2}\right)_{11} \mathrm{SH}\end{array}$ & Quantum dots & $\begin{array}{l}\text { Controllable small } \\
\text { size, narrow size } \\
\text { distribution }\end{array}$ & $\begin{array}{l}\text { Complicated sequential } \\
\text { process }\end{array}$ & 134 \\
\hline $\begin{array}{l}\text { Hydro-thermal } \\
\text { method }\end{array}$ & $\begin{array}{l}\mathrm{AgNO}_{3}, \mathrm{Na}_{2} \mathrm{~S} \\
\mathrm{C}_{3} \mathrm{H}_{6} \mathrm{O}_{2} \mathrm{~S} \\
\mathrm{CH}_{3} \mathrm{COOH} \\
\mathrm{NaOH}\end{array}$ & Quantum dots & $\begin{array}{l}\text { Controllable small } \\
\text { size, narrow size } \\
\text { distribution }\end{array}$ & Sequential process & 135 \\
\hline $\begin{array}{l}\text { Gas-solid } \\
\text { reaction method } \\
\text { on Ag substrate }\end{array}$ & $\begin{array}{l}\mathrm{Ag} \text { foil, } \mathrm{H}_{2} \mathrm{~S} / \mathrm{O}_{2} \\
\text { gas mixture }\end{array}$ & Nanowires & $\begin{array}{l}\text { High aspect ratio, } \\
\text { mono-crystallinity }\end{array}$ & $\begin{array}{l}\text { Elaborate equipment, } \\
\text { complicated process }\end{array}$ & 121 \\
\hline $\begin{array}{l}\text { Solvo-thermal } \\
\text { method }\end{array}$ & $\begin{array}{l}\mathrm{AgNO}_{3}, \\
\mathrm{CH}_{3}\left(\mathrm{CH}_{2}\right)_{17} \mathrm{NH}_{2}\end{array}$ & Ultralong nanowires & $\begin{array}{l}\text { High aspect ratio, } \\
\text { mono-crystallinity }\end{array}$ & Elaborate equipment & 120 \\
\hline $\begin{array}{l}\text { Template solvo- } \\
\text { thermal method } \\
\text { with cation } \\
\text { exchange }\end{array}$ & $\begin{array}{l}\mathrm{S}, \mathrm{Cd}\left(\mathrm{CH}_{3} \mathrm{COO}\right)_{2}, \\
\mathrm{CuCl}, \mathrm{AgNO}_{3}, \\
\text { anhydrous } \\
\mathrm{C}_{2} \mathrm{H}_{5} \mathrm{OH}, \\
\left(\mathrm{CH}_{2} \mathrm{OH}\right)_{2}, \\
\mathrm{NH}_{2} \mathrm{CH}_{2} \mathrm{CH}_{2} \mathrm{NH}_{2}\end{array}$ & Nanowires & $\begin{array}{l}\text { Controllable phase } \\
\text { composition }\end{array}$ & $\begin{array}{l}\text { Elaborate equipment, } \\
\text { complicated sequential } \\
\text { process }\end{array}$ & 124 and 125 \\
\hline $\begin{array}{l}\text { Hydro-chemical } \\
\text { deposition }\end{array}$ & $\begin{array}{l}\mathrm{AgNO}_{3}, \mathrm{Na}_{2} \mathrm{~S}, \\
\mathrm{Na}_{3} \mathrm{Cit} \text { or Trilon } \\
\mathrm{B}\end{array}$ & $\begin{array}{l}\text { Nanoparticles, } \\
\text { quantum dots }\end{array}$ & $\begin{array}{l}\text { Large scale of } \\
\text { products, } \\
\text { controllable size, } \\
\text { safety, simplicity, } \\
\text { non-toxic reagents }\end{array}$ & $\begin{array}{l}\text { Possible presence of } \\
\text { metallic Ag impurity in } \\
\mathrm{Ag}_{2} \mathrm{~S}\end{array}$ & $\begin{array}{l}67,68,136 \\
\text { and } 144\end{array}$ \\
\hline
\end{tabular}

\footnotetext{
${ }^{a}$ PVP - polyvinylpyrrolidone $\left(\mathrm{C}_{6} \mathrm{H}_{9} \mathrm{NO}\right)_{n}$.
} 


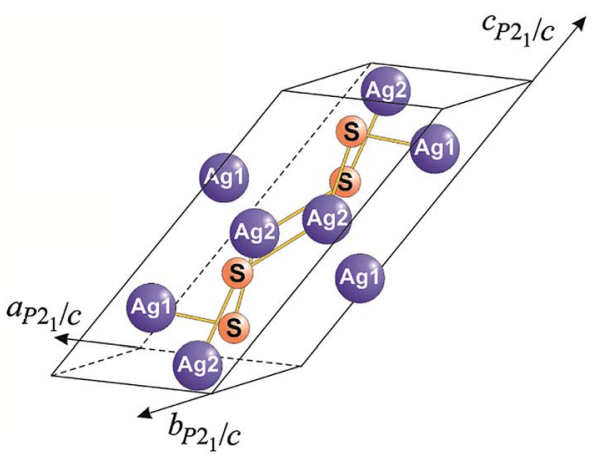

Fig. 12 Monoclinic (space group $P 2_{1} / c$ ) unit cell of $A_{2} S$ with an acanthite structure (only the atoms entering into the unit cell and the nearest bonds between them, Ag1-S and Ag2-S, of length 0.2511 and $0.2548 \mathrm{~nm}$, respectively, are shown). Reprinted from ref. 118 with permission from Elsevier.

$P 2_{1} / c$ ) unit cell parameters were $a=0.42264(2) \mathrm{nm}, b=$ $0.69282(3) \mathrm{nm}, c=0.95317(3) \mathrm{nm}$ and $\beta=125.554(2)^{\circ}$; the site occupancy factor of all crystallographic positions by $\mathrm{Ag}$ and $\mathrm{S}$ atoms was 1.0; the Rietveld reliability factor $R_{\mathrm{I}}\left(R_{\mathrm{B}}\right)$ was 0.0247 . These unit cell parameters were in good agreement with the data. ${ }^{153}$

Thus, artificial coarse-grained $\mathrm{Ag}_{2} \mathrm{~S}$ is stoichiometric. The arrangement of $\mathrm{Ag}$ and $\mathrm{S}$ atoms in the unit cell of artificial monoclinic (space group $P 2_{1} / c$ ) $\mathrm{Ag}_{2} \mathrm{~S}$ with an $\alpha-\mathrm{Ag}_{2} \mathrm{~S}$ acanthite type structure is displayed in Fig. 12.

\subsection{Crystal structure and nonstoichiometry of nanostructured $\alpha-\mathrm{Ag}_{2} \mathrm{~S}$}

Determination of the influence of nanoparticle size on their nonstoichiometry is a fundamental scientific problem.

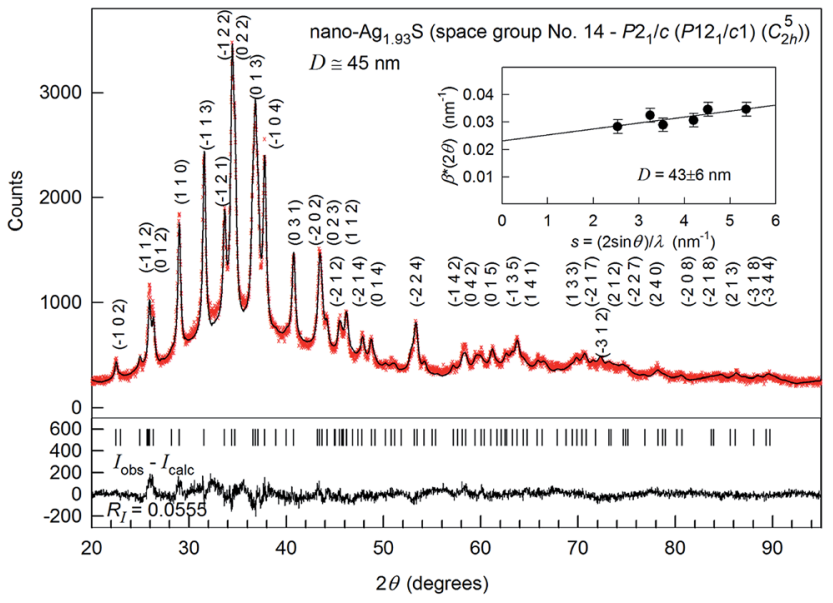

Fig. 13 The experimental $(X)$ and calculated (- - XRD patterns of $\mathrm{Ag}_{1.93} \mathrm{~S}$ nanopowder deposited from a reaction mixture of $\mathrm{AgNO}_{3}$, $\mathrm{Na}_{2} \mathrm{~S}$ and $\mathrm{Na}_{3} \mathrm{Cit}$ having concentrations $0.05,0.025$, and $0.025 \mathrm{moll}^{-1}$, respectively. The difference between the experimental and calculated XRD patterns $\left(I_{\text {obs }}-I_{\text {calc }}\right)$ is shown in the lower part of the figure. The inset presents the estimate of the average CSRs size from the broadening of non-overlapping diffraction reflections. The XRD pattern is recorded in $\mathrm{CuK}_{1}$ radiation. Reproduced from ref. 148 with permission from the PCCP Owner Societies.
A nanostructured $\mathrm{Ag}_{2} \mathrm{~S}$ has been studied extensively in the past two decades. However, until lately, there were no experimental works on the determination of the crystal structure of nanocrystalline $\mathrm{Ag}_{2} \mathrm{~S}$.

Determination of the structure of nanocrystalline $\mathrm{Ag}_{2} \mathrm{~S}$ has been done in study. ${ }^{148}$

The nanocrystalline powder of $\mathrm{Ag}_{2} \mathrm{~S}$ was synthesized by chemical deposition from aqueous solution of $\mathrm{AgNO}_{3}$ and $\mathrm{Na}_{2} \mathrm{~S}$ containing $\mathrm{Na}_{3} \mathrm{Cit}$ as a complexing and stabilizing agent.

The XRD pattern of synthesized $\mathrm{Ag}_{2} \mathrm{~S}$ nanopowder is shown in Fig. 13. According to the BET data, the particle size of the nanopowder was $44 \pm 5 \mathrm{~nm}$.

Preliminary analysis revealed that the synthesized nanocrystalline powder had a monoclinic (space group $\left.P 2_{1} / c\right) \alpha-\mathrm{Ag}_{2} \mathrm{~S}$ acanthite-type structure. The XRD reflections of the nanopowder were broadened and, therefore, the reflections located close to each other overlapped. The average size $D$ of coherent scattering region (CSR) estimated from broadening of nonoverlapping diffraction reflections (-102), (110), (-113), $(-104),(031)$ and (014) was $43 \pm 6 \mathrm{~nm}$.

The coordinates of $\mathrm{Ag}$ and $\mathrm{S}$ atoms and unit cell parameters for $\mathrm{Ag}_{2} \mathrm{~S}$ nanopowder (Table 2) are close to those for coarsecrystalline $\mathrm{Ag}_{2} \mathrm{~S}$. However, the occupancy of crystallographic positions $4(\mathrm{e})$ by $\mathrm{Ag} 1$ and $\mathrm{Ag} 2$ atoms was $\sim 0.97$ and $\sim 0.96$, respectively (Table 2). Hence, $\mathrm{Ag}_{2} \mathrm{~S}$ nanoparticles of size less than $\sim 50 \mathrm{~nm}$ are nonstoichiometric, have a composition of $\sim \mathrm{Ag}_{1.93} \mathrm{~S}$ and contain vacant sites in the metal sublattice.

\subsection{Acanthite $\alpha-\mathrm{Ag}_{2} \mathrm{~S}$-argentite $\beta-\mathrm{Ag}_{2} \mathrm{~S}$ phase transformation}

For the first time, complex in situ high-temperature XRD and SEM study of the $\alpha-\mathrm{Ag}_{2} \mathrm{~S}$ (acanthite) to $\beta-\mathrm{Ag}_{2} \mathrm{~S}$ (argentite) phase transformation in nanocrystalline and coarse-crystalline powders of $\mathrm{Ag}_{2} \mathrm{~S}$ has been carried out in works. ${ }^{162,165,166}$ Until lately, few data on acanthite-argentite phase transformation were obtained only on bulk coarse-crystalline $\mathrm{Ag}_{2} \mathrm{~S}$ samples.

The low-temperature monoclinic phase $\alpha-\mathrm{Ag}_{2} \mathrm{~S}$ (acanthite) exists at temperatures below $\sim 450 \mathrm{~K}$. Argentite $\beta-\mathrm{Ag}_{2} \mathrm{~S}$ has a bcc sublattice of $\mathrm{S}$ atoms and exists in the temperature interval 452859 K.

When argentite $\beta-\mathrm{Ag}_{2} \mathrm{~S}$ is cooled below $450 \mathrm{~K}$ under equilibrium conditions, a polymorphous phase transformation takes place that gives rise to monoclinic acanthite $\alpha-\mathrm{Ag}_{2} \mathrm{~S}$. This transformation is accompanied by distortion of the bcc sublattice of $\mathrm{S}$ atoms to the monoclinic sublattice. The $\mathrm{Ag}$ atoms statistically distributed in positions of the bcc structure of argentite are concentrated in the positions of the monoclinic structure of acanthite, and occupy them with probability close to 1 .

To precisely determine the phase transformation temperature, $\mathrm{Ag}_{2} \mathrm{~S}$ powders were studied via differential thermal analysis-differential thermal gravimetry (DTA-DTG) upon heating and cooling. During heating, the DTA curves had one endothermic peak at about 449-450 K, which corresponded to the $\alpha-\mathrm{Ag}_{2} \mathrm{~S}$ (acanthite) $-\beta-\mathrm{Ag}_{2} \mathrm{~S}$ (argentite) phase transformation. In cooling from $500 \mathrm{~K}$ to room temperature, the DTA dependencies exhibited an exothermal peak related to the argentite- 
Table 2 Refined crystal structure of monoclinic (space group no. $14-P 2_{1} / c\left(P 12_{1} / c 1\right)$ ) Ag $g_{1.93} S$ nanopowder with an $\alpha$-Ag $2 \mathrm{~S}$ acanthite-type structure and particle size $\sim 45 \mathrm{~nm}:{ }^{148} Z=4, a=0.4234(3) \mathrm{nm}, b=0.6949(3) \mathrm{nm}, c=0.9549(5) \mathrm{nm}$, and $\beta=125.43(6)^{\circ}$

\begin{tabular}{|c|c|c|c|c|c|c|}
\hline Atom & $\begin{array}{l}\text { Position and } \\
\text { multiplicity }\end{array}$ & \multicolumn{3}{|c|}{ Atomic coordinates } & Occupancy & $B_{\text {iso }} \times 10^{-4}\left(\mathrm{pm}^{2}\right)$ \\
\hline $\mathrm{Ag} 2$ & $4(\mathrm{e})$ & 0.7264 & $0.3240(9)$ & $0.4375(0)$ & 0.96 & $7.44(6)$ \\
\hline $\mathrm{S}$ & $4(\mathrm{e})$ & 0.4920 & $0.2339(8)$ & $0.1321(1)$ & 1.00 & 1.960 \\
\hline
\end{tabular}

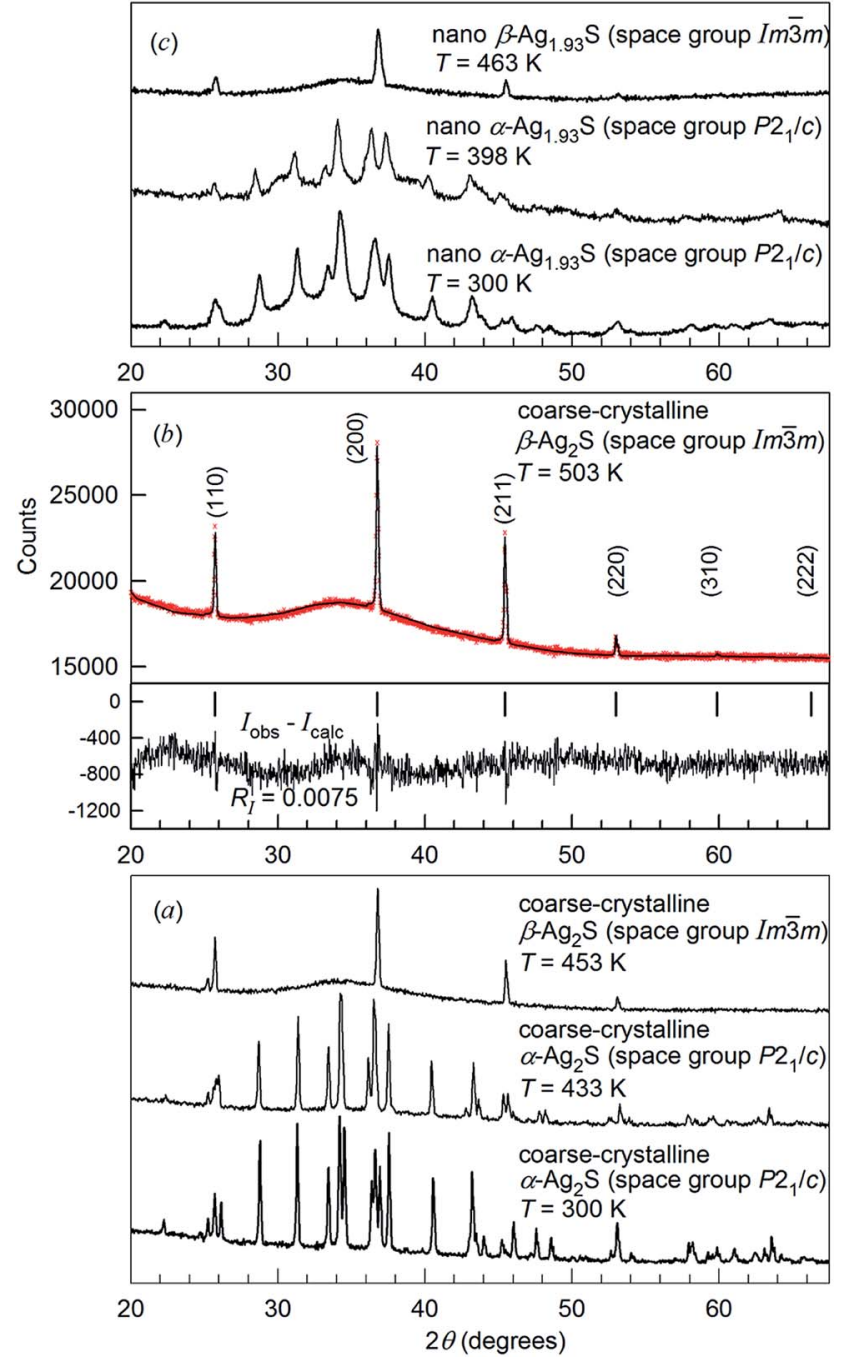

Fig. 14 Evolution of XRD patterns of silver sulfide at heating. ${ }^{162,165,166}$ (a) XRD pattern of coarse-crystalline silver sulfide with a monoclinic (space group $\left.P 2_{1} / c\right) \alpha-\mathrm{Ag}_{2} \mathrm{~S}$ acanthite-type structure at 300 and $433 \mathrm{~K}$, and with a cubic (space group $/ m \overline{3} m$ ) $\beta-\mathrm{Ag}_{2} \mathrm{~S}$ argentite-type structure at 453 K. (b) Experimental $(X)$ and calculated (- X XRD patterns of coarse-crystalline silver sulfide with cubic (space group $/ m \overline{3} m$ ) $\beta-\mathrm{Ag}_{2} \mathrm{~S}$ argentite-type structure at $503 \mathrm{~K}$ and the difference $\left(I_{\text {obs }}-I_{\text {calc }}\right)$ between the experimental and calculated XRD patterns; the ticks correspond to reflections of cubic argentite $\beta-\mathrm{Ag}_{2} \mathrm{~S}$. (c) XRD patterns of nanocrystalline $\mathrm{Ag}_{1.93} \mathrm{~S}$ with a monoclinic (space group $P 2_{1} / \mathrm{C}$ ) acanthite-type structure at 300 and $398 \mathrm{~K}$, and with a cubic (space group $\operatorname{Im} \overline{3} m) \beta-\mathrm{Ag}_{2} \mathrm{~S}$ argentite-type structure at $463 \mathrm{~K}$, respectively. Reproduced from ref. 162 and 166 with permission from the PCCP Owner Societies. to-acanthite phase transformation towards a lower temperature range by $\sim 20 \mathrm{~K}$. The presence of the temperature hysteresis ( $\left.T_{\text {trans }}\right)$ means this was a first-order reversible acanthite-argentite transformation. The enthalpy of the phase transformation $\left(\Delta H_{\text {trans }}\right)$ was $\sim 3.7-3.9 \mathrm{~kJ} \mathrm{~mol}^{-1}$, which is very close to that determined in works ${ }^{167-170}\left(\Delta H_{\text {trans }}=4.0 \pm 0.5 \mathrm{~kJ} \mathrm{~mol}^{-1}\right)$.

The XRD patterns for coarse-crystalline $\mathrm{Ag}_{2} \mathrm{~S}$ powder collected at 300, 433, 453 and $503 \mathrm{~K}$, and the XRD patterns for nanocrystalline $\mathrm{Ag}_{2} \mathrm{~S}$ powder at 300,398 and $463 \mathrm{~K}$ are shown in Fig. 14. The XRD patterns recorded at $T<450 \mathrm{~K}$ (Fig. 14a and c) contained the diffraction reflections of monoclinic (space group $\left.P 2_{1} / c\right) \alpha-\mathrm{Ag}_{2} \mathrm{~S}$ acanthite. The average particle size $D$ in the nanopowder estimated from broadening of diffraction reflections was $\sim 60 \mathrm{~nm}$. According to the DTA data, the transformation of acanthite $\alpha-\mathrm{Ag}_{2} \mathrm{~S}$ into argentite $\beta-\mathrm{Ag}_{2} \mathrm{~S}$ takes place at $\sim 449-450 \mathrm{~K}$. Indeed, the XRD patterns recorded at $T \geq 453 \mathrm{~K}$ contained diffraction reflections of cubic (space group $\operatorname{Im} \overline{3} m$ ) $\beta$ $\mathrm{Ag}_{2} \mathrm{~S}$ argentite. The refinement of the XRD pattern (Fig. 14b) showed that coarse-crystalline $\mathrm{Ag}_{2} \mathrm{~S}$ at $503 \mathrm{~K}$ contained one phase with a cubic (space group no. $229-\operatorname{Im} \overline{3} m(I 4 / m \overline{3} 2 / m)$ $\left(O_{\mathrm{h}}^{9}\right)$ ) structure of $\beta-\mathrm{Ag}_{2} \mathrm{~S}$ argentite (Table 3). According to hightemperature XRD data, ${ }^{162,166}$ the unit cell of $\beta-\mathrm{Ag}_{2} \mathrm{~S}$ argentite includes two $\mathrm{Ag}_{2} \mathrm{~S}$ formula units. Two $\mathrm{S}$ atoms occupy crystallographic positions 2(a) and form a bcc sublattice. Four Ag atoms in $\beta-\mathrm{Ag}_{2} \mathrm{~S}$ argentite are statistically distributed in 54 positions $6(\mathrm{~b})$ and $48(\mathrm{j})$ with the occupation probabilities $\sim 0.0978$ and $\sim 0.0711$, respectively (Table 3 ).

A structure with such small occupancies can be stable only if the mobility of $\mathrm{Ag}$ atoms/ions is very high. The amount of $\mathrm{Ag}^{+}$in argentite $\beta-\mathrm{Ag}_{2} \mathrm{~S}$ is much smaller than the number of sites of the cation sublattice. Therefore, significant positional disorder in an arrangement of $\mathrm{Ag}^{+}$and a gigantic (>92\%) concentration of vacant sites facilitate the "jumping" of cations and provide the superionic conductivity of the $\beta-\mathrm{Ag}_{2} \mathrm{~S}$ phase.

The unit cell of cubic (space group $\operatorname{Im} \overline{3} m$ ) $\beta-\mathrm{Ag}_{2} \mathrm{~S}$ argentite is shown in Fig. 15. Detailed crystallographic information on $\beta$ $\mathrm{Ag}_{2} \mathrm{~S}$ argentite presented as "Crystal structure data" in the CIFfile attached to article. ${ }^{162}$ This CIF number 1062400, which was placed on the Cambridge Crystallographic Data Centre (CCDC) website, can be found at the following electronic address. ${ }^{171}$

Thus, heating of monoclinic $\alpha-\mathrm{Ag}_{2} \mathrm{~S}$ acanthite up to $\sim 449-$ $450 \mathrm{~K}$ leads to a polymorphic phase transition with the formation of bcc $\beta-\mathrm{Ag}_{2} \mathrm{~S}$ argentite.

SEM images of the acanthite-to-argentite transformation occurring in nanocrystalline and coarse-crystalline $\mathrm{Ag}_{2} \mathrm{~S}$ powders are shown in Fig. 16. 
Table 3 Refined crystal structure of cubic (space group no. $\left.229-\operatorname{Im} \overline{3} m(/ 4 / \mathrm{m} \overline{3} 2 / m)\left(O_{h}^{9}\right)\right)$ coarse-crystalline silver sulfide $\beta$ - $\mathrm{Ag}{ }_{2} \mathrm{~S}\left(\beta-\mathrm{Ag}_{2.01} \mathrm{~S}\right)$ with an argentite-type structure at $503 \mathrm{~K}:{ }^{162,166,166} \mathrm{Z}=2, \mathrm{a}=b=c=0.4874(1) \mathrm{nm}$

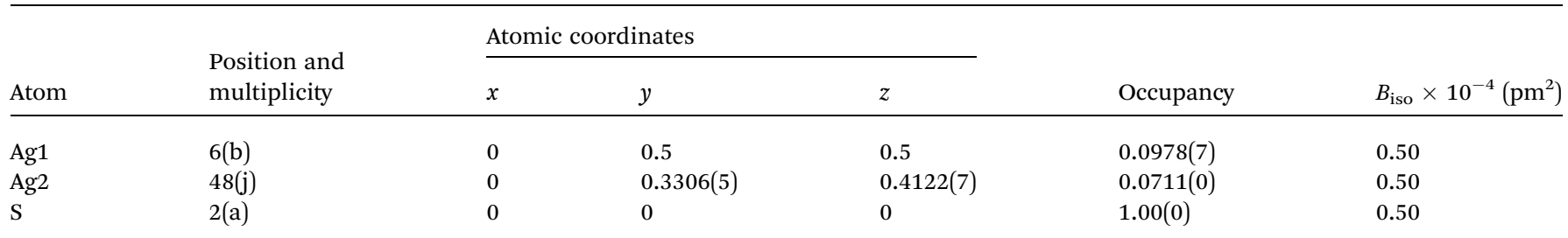
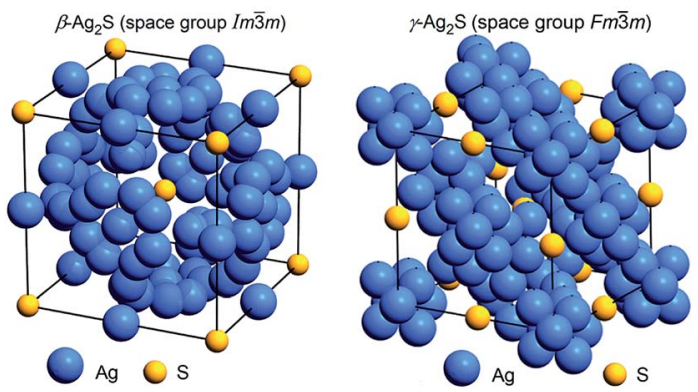

Fig. 15 The arrangement of $\mathrm{Ag}$ and $\mathrm{S}$ atoms in the unit cells of cubic (space group $\operatorname{Im} \overline{3} m$ ) $\beta-\mathrm{Ag}_{2} \mathrm{~S}$ argentite ${ }^{162}$ and cubic (space group $\mathrm{Fm} \overline{3} \mathrm{~m}) \gamma-\mathrm{Ag}_{2} \mathrm{~S} .{ }^{155}$ Positions of silver sublattices on which Ag atoms are statistically distributed are shown. Reproduced from ref. 162 with permission from the PCCP Owner Societies.

In the upper row (Fig. 16a-c) the initial nanopowder with a surface area (for which the elemental chemical composition was determined by EDX) as well as the cumulative elemental EDX pattern of the initial powder are shown. According to the EDX data (Fig. 16c), the content of $\mathrm{Ag}$ and $\mathrm{S}$ in the $\mathrm{Ag}_{2} \mathrm{~S}$ nanopowder determined from the integral intensities AgL and SK lines were $86.8 \pm 0.4$ and $13.1 \pm 0.1 \mathrm{wt} \%$. This corresponds to a sulfide which is close to the stoichiometric composition of $\mathrm{Ag}_{2} \mathrm{~S}$ but with small deficiency of silver. The second row
(Fig. 16d-f) show a SEM image of the electron beam-heated surface area, upon which argentite particles are growing, and of the same area (side view) with grown argentite crystals.

Short pyramidal nuclei of argentite crystallites (whose base was about 50-80 $\mathrm{nm}$ in thickness) appeared on the surface of $\mathrm{Ag}_{2} \mathrm{~S}$ powder particles $\sim 30 \mathrm{~s}$ after the start of heating. As a result of heating, the nuclei grew quickly, taking the shape of whiskers, and in $\sim 5$ min covered the entire surface of the acanthite particle.

The sequence of formation and growth of argentite nanoparticles can be conventionally divided into four stages. First, as a result of electron-beam irradiation of acanthite, the particles are heated. Second, the phase transformation leads to the formation of argentite, so the appearance and growth of argentite nuclei take place on the surface of acanthite particles. The third stage is connected with the growth of argentite particles as a result of further heating and the argentite nuclei interacting with the low-temperature phase of acanthite acting as a donor. The growth of argentite particles ends at the fourth stage when no low-temperature acanthite remains in the surface layer.

The formation of argentite was also confirmed by HRTEM data. Fig. 17 demonstrates the HRTEM and TEM images of $\mathrm{Ag}_{2} \mathrm{~S}$ nanopowder before and after radiation heating. ${ }^{162}$ In Fig. 17a, the interplanar distance is $0.309 \mathrm{~nm}$ and clearly visible, which
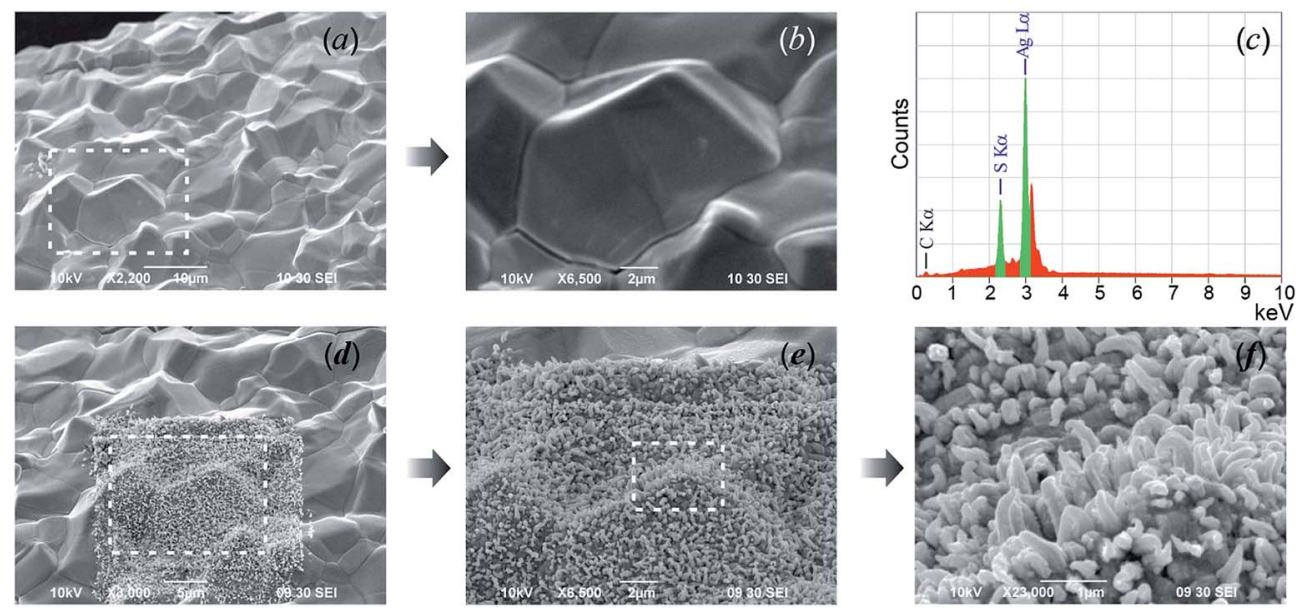

Fig. 16 The transformation of acanthite $\alpha-\mathrm{Ag}_{2} \mathrm{~S}$ into argentite $\beta-\mathrm{Ag}_{2} \mathrm{~S}$. Upper row: (a and b) the initial nanopowder and (c) its cumulative elemental EDX pattern. Second row: $(d-f)$ the argentite particles are growing on the electron beam-heated surface area. The white dotted lines show the surface areas of $\mathrm{Ag}_{2} \mathrm{~S}$ powders heated by the electron beam. Reproduced from ref. 162 with permission from the PCCP Owner Societies. 


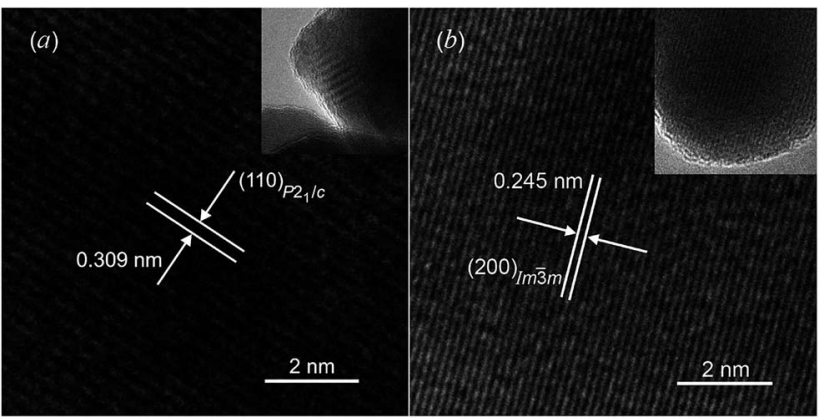

Fig. 17 HRTEM images of silver sulfide nanoparticles: (a) the interplanar distance $(0.309 \mathrm{~nm})$ observed before heating corresponds to monoclinic silver sulfide with an $\alpha-\mathrm{Ag}_{2} \mathrm{~S}$ acanthite-type structure; (b) the interplanar distance $(0.245 \mathrm{~nm})$ observed after heating corresponds to a cubic silver sulfide with $\beta-\mathrm{Ag}_{2} \mathrm{~S}$ argentite-type structure. The insets show the TEM images of nanoparticles at lower magnification. Reproduced from ref. 162 with permission from the PCCP Owner Societies.

coincides with the distance $d_{(110)}$ between atomic planes (110) of $\mathrm{Ag}_{2} \mathrm{~S}$ with a monoclinic (space group $P 2_{1} / c$ ) $\alpha-\mathrm{Ag}_{2} \mathrm{~S}$ acanthite structure. Upon radiation heating of the nanopowder, the HRTEM image exhibits an interplanar distance of $0.245 \mathrm{~nm}$ (Fig. 17b). This corresponds to the distance between the atomic planes (200) of cubic (space group $\operatorname{Im} \overline{3} m$ ) $\mathrm{Ag}_{2} \mathrm{~S}$ with a $\beta-\mathrm{Ag}_{2} \mathrm{~S}$ argentite structure. The insets in Fig. 17 correspond to the TEM images of these nanopowders of $\mathrm{Ag}_{2} \mathrm{~S}$ before and after heating.

\subsection{Crystal structure of the $\gamma-\mathrm{Ag}_{2} \mathrm{~S}$ phase and distributions of $\mathrm{Ag}$ atoms in cubic $\mathrm{Ag}_{2} \mathrm{~S}$}

At temperatures above $860 \mathrm{~K}, \mathrm{Ag}_{2} \mathrm{~S}$ contains a cubic (space group $\left.F m \overline{3} m(F 4 / m \overline{3} 2 / m)\left(O_{\mathrm{h}}^{5}\right)\right) \gamma-\mathrm{Ag}_{2} \mathrm{~S}$ phase. The unit cell of the $\gamma-\mathrm{Ag}_{2} \mathrm{~S}$ phase includes four formula units of $\mathrm{Ag}_{2} \mathrm{~S}(z=4)$. The first structural model of high-temperature cubic $\gamma-\mathrm{Ag}_{2} \mathrm{~S}$ was proposed in study. ${ }^{172}$ According to, ${ }^{172}$ four $\mathrm{S}$ atoms occupy crystallographic positions 4(a) and form a fcc sublattice, and eight $\mathrm{Ag}$ atoms are statistically distributed in $8(\mathrm{c})$ and $32(\mathrm{f})$ positions. Blanton et al. ${ }^{155}$ using high-temperature XRD data, refined the model ${ }^{172}$ by distributing $\mathrm{Ag}$ atoms on positions $48(\mathrm{i})$ also (Table 4). According to, ${ }^{155}$ at $923 \mathrm{~K}$, eight Ag atoms are statistically distributed in 88 positions 8 (c), 32(f) and 48(i) with the occupation probabilities $\sim 0.088, \sim 0.15$, and $\sim 0.027$, respectively. Model ${ }^{155}$ suggests some Ag deficiency in the $\gamma$ -

Table 4 Crystal structure of cubic (space group no. $225-F m \overline{3} m$ (F4/ $\left.m \overline{3} 2 / m)\left(O_{\mathrm{h}}^{5}\right)\right) \gamma-\mathrm{Ag}_{2} \mathrm{~S}$ silver sulfide at $923 \mathrm{~K}:{ }^{155} \mathrm{Z}=4, a=b=c=$ $0.62831(8) \mathrm{nm}$

\begin{tabular}{llllll}
\hline & & \multicolumn{2}{l}{ Atomic coordinates } & \\
Atom & $\begin{array}{l}\text { Position and } \\
\text { multiplicity }\end{array}$ & $x$ & $y$ & $z$ & Occupancy \\
\hline Ag1 & $8(\mathrm{c})$ & 0.25 & 0.25 & 0.25 & $0.088(7)$ \\
$\mathrm{Ag} 2$ & $32(\mathrm{f})$ & $0.303(4)$ & $0.303(4)$ & $0.303(4)$ & $0.15(1)$ \\
$\mathrm{Ag} 3$ & $48(\mathrm{i})$ & 0.5 & $0.381(4)$ & $0.381(4)$ & $0.027(3)$ \\
$\mathrm{S}$ & $4(\mathrm{a})$ & 0 & 0 & 0 & 1
\end{tabular}

phase corresponding to nonstoichiometric $\mathrm{Ag}_{1.7} \mathrm{~S}$. Fig. 15 shows the crystal structure of $\gamma-\mathrm{Ag}_{2} \mathrm{~S}$ proposed in study. ${ }^{155}$

Using the temperature dependences of the crystal lattice parameters of monoclinic acanthite $\alpha-\mathrm{Ag}_{2} \mathrm{~S}$, cubic argentite $\beta$ $\mathrm{Ag}_{2} \mathrm{~S}$, and cubic phase $\gamma-\mathrm{Ag}_{2} \mathrm{~S}$, it is possible to estimate the interatomic distances in these phases at comparable temperatures close to the $\alpha-\mathrm{Ag}_{2} \mathrm{~S}-\beta-\mathrm{Ag}_{2} \mathrm{~S}$ and $\beta-\mathrm{Ag}_{2} \mathrm{~S}-\gamma-\mathrm{Ag}_{2} \mathrm{~S}$ transformation temperatures. The least distance between the Ag1 and $\mathrm{Ag} 1$ atoms in the crystal lattice of monoclinic $\alpha-\mathrm{Ag}_{2} \mathrm{~S}$ acanthite at $433 \mathrm{~K}$ is $0.3351 \mathrm{~nm}$, and the least distance between the Ag1 and $\mathrm{Ag} 2$ atoms is in the interval from 0.3085 to $0.3200 \mathrm{~nm} \cdot{ }^{166,173}$ The covalent diameter of the $\mathrm{Ag}$ atom is $\sim 0.292 \mathrm{~nm}$. With that in mind, it is clear that $\mathrm{Ag}$ atoms in monoclinic acanthite are at rather large distances from each other and, therefore, occupy their crystallographic sites with a probability $\sim 1$. According to, ${ }^{\mathbf{1 6 6 , 1 7 3}}$ in the crystal lattice of cubic $\beta-\mathrm{Ag}_{2} \mathrm{~S}$ argentite at $443 \mathrm{~K}$, the least possible distance between the Ag1 and Ag1 atoms is $0.2428 \mathrm{~nm}$, between the Ag1 and Ag2 atoms is from 0.0927 to $0.2971 \mathrm{~nm}$, and between the Ag2 and Ag2 atoms is from 0.0988 to $0.2998 \mathrm{~nm}$. Thus, in cubic argentite, the possible distances between $\mathrm{Ag}$ atoms are too small for the 6(b) and 48(j) positions to be occupied by $\mathrm{Ag}$ atoms with a probability of 1 . Indeed, the occupancies of the $6(\mathrm{~b})$ and $48(\mathrm{j})$ positions by $\mathrm{Ag}$ atoms in $\beta-\mathrm{Ag}_{2} \mathrm{~S}$ (in other words, the probabilities of finding $\mathrm{Ag}$ atoms in the 6(b) and $48(\mathrm{j})$ sites) are very small and equal to $\sim 0.0978$ and $\sim 0.0711$, respectively. In the cubic $\gamma-\mathrm{Ag}_{2} \mathrm{~S}$ phase, the possible distances between $\mathrm{Ag}$ atoms are too small for the 8(c), 32(f) and 48(i) positions to be occupied by $\mathrm{Ag}$ atoms with a probability of 1 . Therefore, the probabilities of filling of the 8(c), 32(f) and 48(i) sites by $\mathrm{Ag}$ atoms are $<0.1$. Physically, this means that $\mathrm{Ag}$ atoms in the lattices of cubic $\beta$ $\mathrm{Ag}_{2} \mathrm{~S}$ and $\gamma-\mathrm{Ag}_{2} \mathrm{~S}$ phases are in constant motion over all possible crystallographic positions. It is this constant motion of $\mathrm{Ag}$ atoms that provides the stability of crystal lattices of cubic $\beta$ $\mathrm{Ag}_{2} \mathrm{~S}$ and $\gamma-\mathrm{Ag}_{2} \mathrm{~S}$ phases, and their superionic conductivity as distinct from the semiconducting $\alpha-\mathrm{Ag}_{2} \mathrm{~S}$ acanthite.

\section{Effect of small particle size on the thermal expansion and heat capacity of $\mathrm{Ag}_{2} \mathrm{~S}$}

For the application of nanocrystalline $\mathrm{Ag}_{2} \mathrm{~S}$ in infrared equipment, solar-energy converters and resistive switches, it is necessary to have information about the variation in the thermal expansion coefficient of different $\mathrm{Ag}_{2} \mathrm{~S}$ phases versus the temperature, and about the effect of particle size on such lattice properties of $\mathrm{Ag}_{2} \mathrm{~S}$ as heat capacity and thermal expansion.

According to, ${ }^{\mathbf{1 6 9}}$ the linear thermal expansion coefficient $\alpha_{\mathrm{ac}}$ of acanthite is $\sim 20 \times 10^{-6} \mathrm{~K}^{-1}$. According to, ${ }^{174}$ in the temperature range $293-450 \mathrm{~K}$, the $\alpha_{\mathrm{ac}}$ of bulk acanthite is $16.8 \times$ $10^{-6} \mathrm{~K}^{-1}$, and the linear thermal expansion coefficient $\alpha_{\text {arg }}$ of bulk argentite is $45.8 \times 10^{-6} \mathrm{~K}^{-1}$ from $\sim 460$ to $570 \mathrm{~K}$.

A systematic in situ study of the thermal expansion of coarsecrystalline and nanocrystalline powders of $\mathrm{Ag}_{2} \mathrm{~S}$ in the region of existence of monoclinic $\alpha-\mathrm{Ag}_{2} \mathrm{~S}$ acanthite and cubic $\beta-\mathrm{Ag}_{2} \mathrm{~S}$ 
argentite has been done for the first time in works ${ }^{\mathbf{1 6 6 , 1 7 3}}$ via a high-temperature XRD method. Recently, direct dilatometric measurements of the thermal expansion of coarse-crystalline and nanocrystalline $\mathrm{Ag}_{2} \mathrm{~S}$ at 290 to $970 \mathrm{~K}$ in the region of existence of monoclinic acanthite $\alpha-\mathrm{Ag}_{2} \mathrm{~S}$, argentite $\beta-\mathrm{Ag}_{2} \mathrm{~S}$, and $\gamma$ $\mathrm{Ag}_{2} \mathrm{~S}$ phases, as well as the heat capacity of nanocrystalline $\mathrm{Ag}_{2} \mathrm{~S}$ in the temperature interval from 300 to $930 \mathrm{~K}$, have been carried out in study. ${ }^{\mathbf{1 7 5}}$

The average particle size in coarse- and nanocrystalline $\mathrm{Ag}_{2} \mathrm{~S}$ powders was $\sim 430$ and $\sim 66 \mathrm{~nm}$.

The effect of temperature on the evolution of XRD patterns of nanocrystalline $\mathrm{Ag}_{2} \mathrm{~S}$ is shown in Fig. 14. The XRD patterns of $\mathrm{Ag}_{2} \mathrm{~S}$ recorded at $<450 \mathrm{~K}$ contain the diffraction reflections of monoclinic (space group $P 2_{1} / c$ ) acanthite $\alpha-\mathrm{Ag}_{2} \mathrm{~S}$, and the XRD patterns recorded at $>450 \mathrm{~K}$ contain the diffraction reflections of cubic (space group $\operatorname{Im} \overline{3} m$ ) argentite $\beta-\mathrm{Ag}_{2} \mathrm{~S}$. Thus, a polymorphous phase transformation of monoclinic acanthite $\alpha$ $\mathrm{Ag}_{2} \mathrm{~S}$ into bcc argentite $\beta-\mathrm{Ag}_{2} \mathrm{~S}$ takes place at $\sim 448-453 \mathrm{~K}$.

According to data from high-temperature XRD studies, ${ }^{\mathbf{1 6 6 , 1 7 3}}$ the isotropic (averaged in all crystallographic directions) linear thermal expansion coefficient $\alpha_{\text {ac-nano }}$ of nanocrystalline acanthite in the temperature range $300-400 \mathrm{~K}$ is

$$
\alpha_{\text {ac-nano }}(T)=13.4 \times 10^{-6}+2.7 \times 10^{-8} T \pm 2 \times 10^{-6}\left[\mathrm{~K}^{-1}\right]
$$

The $\alpha_{\text {ac-nano }}$ of nanocrystalline acanthite is $\sim 25 \%$ larger than the analogous coefficient $\alpha_{\mathrm{ac}}$ of coarse-crystalline acanthite. The difference in the coefficients $\alpha_{\text {ac-nano }}$ and $\alpha_{\text {ac }}$ is due to the small particle size in nanocrystalline acanthite. Earlier, a similar difference in the linear thermal expansion coefficients of nanocrystalline film and coarse-grained sample was observed for $\mathrm{PbS} .^{4,176,177}$

According to, ${ }^{\mathbf{1 6 6 , 1 7 3}}$ the dependence of $\alpha_{\text {arg }}$ on the annealing temperature $T$ in the range $443-623 \mathrm{~K}$ can be represented as

$$
\alpha_{\arg }(T)=84.5 \times 10^{-6}-6.9 \times 10^{-8} T \pm 3 \times 10^{-6}\left[\mathrm{~K}^{-1}\right] .
$$

The temperature dependences of $\alpha_{\text {aver }}(T)$ for coarse- and nanocrystalline $\mathrm{Ag}_{2} \mathrm{~S}$ measured by dilatometry are demonstrated in Fig. 18. The largest coefficient $\alpha_{\text {aver }}(T)$ in the examined temperature range $293-970 \mathrm{~K}$ belonged to nanocrystalline $\mathrm{Ag}_{2} \mathrm{~S}$ produced from a powder with an average particle size of $\sim 66 \mathrm{~nm}$. The average linear thermal expansion coefficients $\alpha_{\text {aver }}$ of coarse-crystalline and nanocrystalline acanthite $\alpha-\mathrm{Ag}_{2} \mathrm{~S}$ and argentite $\beta-\mathrm{Ag}_{2} \mathrm{~S}$ measured in works ${ }^{166,173}$ by high-temperature XRD are shown in Fig. 18 for comparison. The results of dilatometric and high-temperature XRD measurements of $\alpha_{\text {aver }}$ agree with each other satisfactorily.

The heat capacity of $\mathrm{Ag}_{2} \mathrm{~S}$ nanopowder changes monotonically with rising temperature, except for the transition regions (Fig. 19). In the temperature range 300-450 $\mathrm{K}$, the heat capacity increases and then, near the transition temperature $T_{\alpha-\beta}$, it experiences a discontinuity. In the region of existence of the $\beta-\mathrm{Ag}_{2} \mathrm{~S}$ phase, in the temperature interval from $\sim 470$ to $\sim 840 \mathrm{~K}$, the heat capacity first decreases slightly to $\sim 670 \mathrm{~K}$ and then grows slightly to the transition temperature $T_{\beta-\gamma}$, where it discontinues. As the temperature increases further to $\sim 890 \mathrm{~K}$,

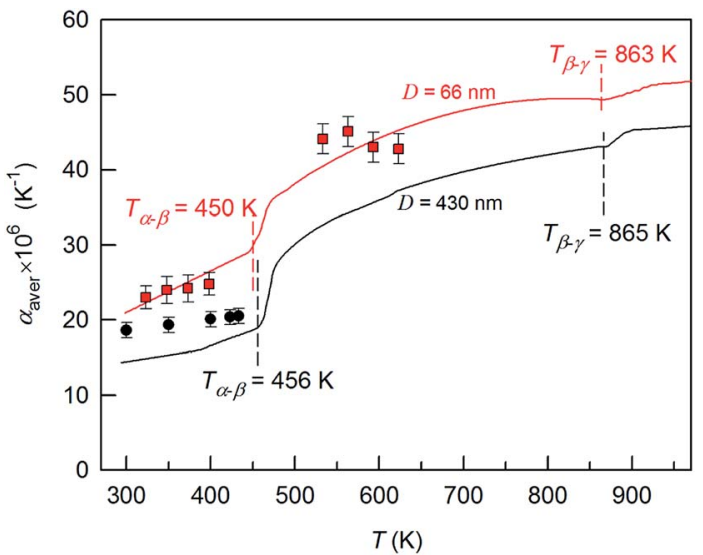

Fig. 18 The average thermal expansion coefficients $\alpha_{\text {aver }}$ of coarseand nanocrystalline silver sulfide measured by dilatometry in the temperature range 293-970 K. The thermal expansion coefficient $\alpha_{\text {aver }}$ of coarse-crystalline ( $(\bullet)$ and nanocrystalline $(\square)$ silver sulfides measured in works ${ }^{166,173}$ by the high-temperature XRD method are shown for comparison. The discontinuity regions of the coefficient $\alpha(T)$ are shown by a dotted line. Reproduced from ref. 175 with permission of Springer.

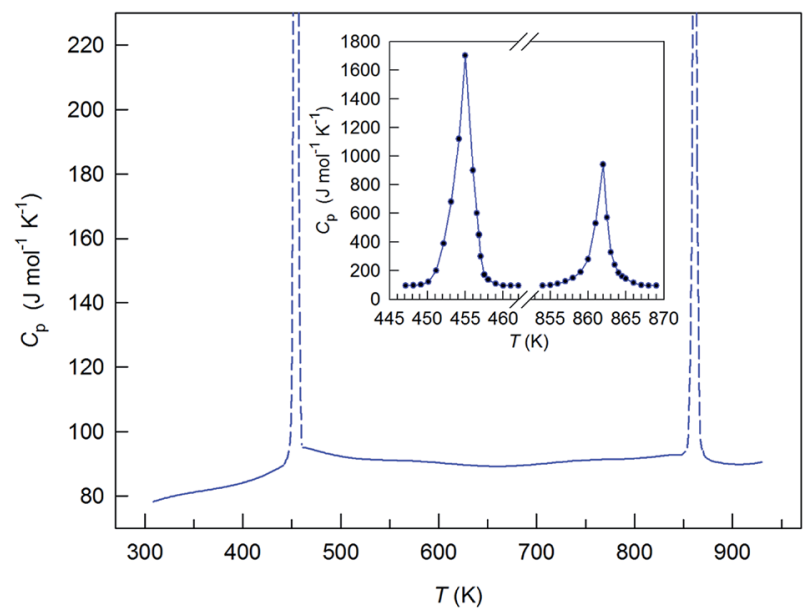

Fig. 19 Heat capacity of silver sulfide nanopowder. The inset shows the spasmodic change of $C_{p}$ for $A_{2} S$ nanopowder in the regions of $\alpha$ $\mathrm{Ag}_{2} \mathrm{~S}-\beta-\mathrm{Ag}_{2} \mathrm{~S}$ and $\beta-\mathrm{Ag}_{2} \mathrm{~S}-\gamma-\mathrm{Ag}_{2} \mathrm{~S}$ transformations. Reproduced from ref. 175 with permission of Springer.

a small reduction of the heat capacity is observed and, at $T>890 \mathrm{~K}$, the heat capacity increases slightly. According to the heat capacity measurements, the transition temperatures $T_{\alpha-\beta}$ and $T_{\beta-\gamma}$ were 451 and $858 \mathrm{~K}$, respectively.

The peaks of the heat capacity $C_{\mathrm{p}}$ of $\mathrm{Ag}_{2} \mathrm{~S}$ nanopowder in the $\alpha-\mathrm{Ag}_{2} \mathrm{~S}-\beta-\mathrm{Ag}_{2} \mathrm{~S}$ and $\beta-\mathrm{Ag}_{2} \mathrm{~S}-\gamma-\mathrm{Ag}_{2} \mathrm{~S}$ transformation regions were symmetric rather than $\lambda$-shaped (Fig. 19, inset). A symmetric shape of the observed peaks is more characteristic of first-order phase transitions. The heat capacity peaks were very narrow (the width of peak base was about $8 \mathrm{~K}$ ), which is also typical for firstorder phase transitions.

The enthalpy of the phase transformations $\alpha-\mathrm{Ag}_{2} \mathrm{~S}-\beta-\mathrm{Ag}_{2} \mathrm{~S}$ and $\beta-\mathrm{Ag}_{2} \mathrm{~S}-\gamma-\mathrm{Ag}_{2} \mathrm{~S}$ was estimated to be $\Delta H_{\alpha-\beta}=4.2 \pm 0.4$ and 
$\Delta H_{\beta-\gamma}=1.2 \pm 0.3 \mathrm{~kJ} \mathrm{~mol}^{-1}$, respectively. According to data, ${ }^{\mathbf{1 6 7 , 1 6 8 , 1 7 0}}$ the enthalpy $\Delta H_{\alpha-\beta}$ is $3.98,3.93$, and $4.06 \mathrm{~kJ} \mathrm{~mol}^{-1}$, respectively. According to, ${ }^{\mathbf{1 6 2 , 1 6 5 , 1 6 6}}$ the enthalpy $\Delta H_{\alpha-\beta}$ is 3.7-3.9 $\mathrm{kJ} \mathrm{mol}^{-1}$. As reported in, ${ }^{\mathbf{1 6 8 , 1 7 0}}$ the enthalpy $\Delta H_{\beta-\gamma}$ of the transformation of argentite $\beta-\mathrm{Ag}_{2} \mathrm{~S}$ into the $\gamma-\mathrm{Ag}_{2} \mathrm{~S}$ phase was $\sim 0.50$ and $\sim 0.78 \mathrm{~kJ} \mathrm{~mol}^{-1}$, respectively. Within the measurement error, the obtained values of enthalpies $\Delta H_{\alpha-\beta}$ and $\Delta H_{\beta-\gamma}$ were close to the literature data.

For comparison, Fig. 20 presents experimental data on the heat capacity $C_{\mathrm{p}}$ of nanocrystalline $\mathrm{Ag}_{2} \mathrm{~S}^{\mathbf{1 7 5}}$ and the most reliable experimental data from the literature on the $C_{\mathrm{p}}$ of coarsegrained $\mathrm{Ag}_{2} \mathrm{~S}^{\mathbf{1 7 0}}$ obtained with the use of adiabatic-shell calorimetry. In the whole temperature region, the heat capacity of nanocrystalline $\mathrm{Ag}_{2} \mathrm{~S}$ measured in study ${ }^{175}$ was $1-4 \%$ larger than the heat capacity of coarse-crystalline sulfide. ${ }^{\mathbf{1 7 0}}$ The measured heat capacity $C_{\mathrm{p}}$ peaks of $\mathrm{Ag}_{2} \mathrm{~S}$ nanopowder was slightly broadened in temperature as compared with those for bulk $\mathrm{Ag}_{2} \mathrm{~S}$ obtained in study. ${ }^{\mathbf{1 7 0}}$

The main reason of variation of the lattice properties of nanocrystals in comparison with bulk substances is variation of the shape and boundaries of the phonon spectrum, i.e. change of the frequency distribution function of atomic vibrations. ${ }^{\mathbf{1 7 6}}$

According to, ${ }^{\mathbf{1 7 8 , 1 7 9}}$ waves can occur in nanoparticles whose length does not exceed the doubled maximum size of the particle $D$, i.e., $\lambda \leq 2 D$. Hence, on the side of low-frequency vibrations, the phonon spectrum is limited by a certain minimal frequency $\omega_{\min } \geq 2 \pi \frac{c_{\mathrm{t}}}{2 D}$, where $c_{\mathrm{t}}$ is the velocity of propagation of transverse elastic vibrations (i.e., transverse velocity of sound). In bulk crystals, there is no limitation like this. Besides, the phonon spectrum is limited on the side of high frequencies.

Studies, ${ }^{176,177}$ took into consideration the restrictions of the phonon spectrum of the small particles and used the approach $^{\mathbf{1 8 0}}$ for the upper boundary $\omega_{\max }$ of the phonon spectrum of small particles. They showed that the molar heat capacity of a model nanocrystalline substance with particles of

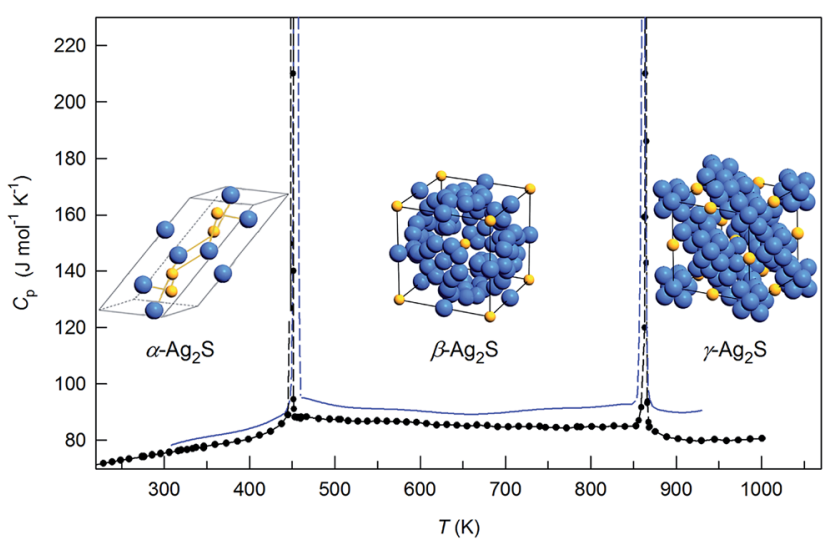

Fig. 20 Heat capacity of silver sulfide nanopowder. For comparison, the heat capacity ( ) of coarse-grained $\mathrm{Ag}_{2} \mathrm{~S}^{170}$ is shown. The unit cells of $\alpha-\mathrm{Ag}_{2} \mathrm{~S}$ acanthite, $\beta-\mathrm{Ag}_{2} \mathrm{~S}$ argentite and $\gamma-\mathrm{Ag}_{2} \mathrm{~S}$ phase are shown in the temperature regions of existence of these phases. Reproduced from ref. 175 with permission of Springer. a cubic shape with edges in length $D$ can be presented as a function not only of the temperature $T$, but also of the size $D$ of the small particle:

$$
C_{\mathrm{V}}(T, D)=C_{\mathrm{V}}^{\mathrm{bulk}}(T)+n\left(\frac{12 v_{\mathrm{m}} k_{1} T}{D^{2}}+\frac{6 v_{\mathrm{m}} k_{2} T^{2}}{D}\right),
$$

where the first summand represents the Debye heat capacity of bulk crystal in the low-temperature region. The values $k_{1}=\left(k_{\mathrm{B}}{ }^{2} c_{1}{ }^{-1} / 8 \pi \hbar\right) I_{2}$ and $k_{2}=\left(k_{\mathrm{B}}{ }^{3} c_{2}{ }^{-1} / 2 \pi \hbar^{2}\right) I_{3}$ are positive constants, including the Riemann zeta functions and effective propagation velocities of elastic vibrations, $c_{1}{ }^{-1}$ and $c_{2}{ }^{-1}$.

The linear thermal expansion coefficient $\alpha(T)$ is related to heat capacity $C_{\mathrm{V}}$ by the known relationship

$$
\alpha(T)=\frac{\gamma}{3 B} \frac{C_{\mathrm{V}}(T)}{v_{\mathrm{m}}},
$$

where $B$ is the bulk modulus, $v_{\mathrm{m}}$ is the molar volume, and $\gamma$ is the Grüneisen constant.

With allowance for eqn (9) and (10), the thermal expansion coefficient of nanocrystalline substance can be presented as

$$
\alpha(T, D)=\alpha_{\text {bulk }}(T)+n \frac{\gamma}{3 B}\left(\frac{12 k_{1} T}{D^{2}}+\frac{6 k_{2} T^{2}}{D}\right) .
$$

Thus, the heat capacity and the thermal expansion coefficient of a nanocrystalline substance include an additional positive contribution as compared with the same properties of a coarse-grained (bulk) substance. Exactly this result was observed for the heat capacity and the thermal expansion coefficient of nanocrystalline and coarse-grained (bulk) $\mathrm{Ag}_{2} \mathrm{~S}$. The appearance of a positive contribution is due to the restriction of the phonon spectrum on the side of low and high frequencies.

According to, ${ }^{\mathbf{1 6 6}}$ the reduction of the particle size in $\mathrm{Ag}_{2} \mathrm{~S}$ is accompanied by enhancement of the anharmonicity of atomic vibrations. Anharmonicity results in enhanced phononphonon scattering, which reduces the thermal conductivity $\kappa$ and increases the $Z T$ of nanostructured $\mathrm{Ag}_{2} \mathrm{~S}$. This confirms the possibility of application of nanostructured $\mathrm{Ag}_{2} \mathrm{~S}$ as a thermoelectric material that it was noted in study. ${ }^{58}$

\section{Heteronanostructures based on $\mathrm{Ag}_{2} \mathrm{~S}$}

Semiconductor-metal hybrid heteronanostructures may exhibit not only a combination of properties of the separate components but also further enhanced property tunability. It is supposed that, owing to synergetic effects, new improved properties will arise from the interactions between the metal and semiconductor.

Among semiconductor-metal nanocomposites, the heteronanostructures based on $\mathrm{Ag}_{2} \mathrm{~S}$ have attracted special attention and are very useful for manifold applications. $\mathrm{Ag}_{2} \mathrm{~S}$-based heteronanostructures can be used in infrared detectors, in resistance-switches and nonvolatile memory devices, and for bioimaging as biomarkers. ${ }^{2,5,16,43,48-50,181-183}$ According to, ${ }^{184,185}$ 
$\mathrm{Ag}_{2} \mathrm{~S}$-based heteronanostructures exhibit an excellent bactericidal effect against many types of bacteria. In recent years, $\mathrm{Ag}_{2} \mathrm{~S}$ based semiconductor-metal heterostructures have emerged as one of the leading materials for photocatalytic conversion of sunlight energy. ${ }^{186-188}$

Synthesis of $\mathrm{Ag}_{2} \mathrm{~S} / \mathrm{M}(\mathrm{M}=\mathrm{Ag}, \mathrm{Au}, \mathrm{Pt}, \mathrm{Pd}, \mathrm{Os})$ heteronanostructures was studied in detail by Yang, Ying and coauthors. ${ }^{16,40,189,190}$ They developed a general scheme for transferring the transition metal ions from water to an organic medium using an ethanol-mediated route, which was extended to preparation of a variety of semiconductor/noble-metal heteronanostructures.

A room-temperature method was developed to first derive aqueous-dispersible $\mathrm{Ag}_{2} \mathrm{~S}$ nanocrystals. Typically, $\mathrm{C}_{18} \mathrm{H}_{17} \mathrm{~K}_{2} \mathrm{O}_{8} \mathrm{PS}_{2}$ salt was added to aqueous $\mathrm{AgNO}_{3}$ solution. The mixture was stirred for $1 \mathrm{~h}$ to form Ag-complexes, with subsequent prompt addition of aqueous $\mathrm{Na}_{2} \mathrm{~S}$ solution, which resulted in $\mathrm{Ag}_{2} \mathrm{~S}$ hydrosol being produced. ${ }^{40}$ Then, $\mathrm{Ag}_{2} \mathrm{~S}$ nanocrystals were used as seeds for the formation of nanocomposites with different metals. By using $7 \mathrm{~nm} \mathrm{Ag}_{2} \mathrm{~S}$ nanocrystals, $\mathrm{Na}_{3} \mathrm{Cit}$, and various noble-metal precursors at $378 \mathrm{~K}$ (for gold) and $383 \mathrm{~K}$ (for other noble metals), a set of $\mathrm{Ag}_{2} \mathrm{~S} / \mathrm{M}$ heteronanostructures were obtained, such as $\mathrm{Ag}_{2} \mathrm{~S} / \mathrm{Au}$ and $\mathrm{Ag}_{2} \mathrm{~S} / \mathrm{Ag}$ (Fig. 21), $\mathrm{Ag}_{2} \mathrm{~S} / \mathrm{Pt}, \mathrm{Ag}_{2} \mathrm{~S} /$ Os, and $\mathrm{Ag}_{2} \mathrm{~S} / \mathrm{Pd}$. In the presence of $\mathrm{Ag}_{2} \mathrm{~S}$ seeds, the metals nucleated preferentially on the existing $\mathrm{Ag}_{2} \mathrm{~S}$ seeds rather than homogeneously.

Cation-exchange reactions can also be used to prepare heteronanostructures through the partial transformation of ionic nanocrystals. ${ }^{2}$

The chemical transformation of nanocrystalline solids has emerged as a very promising strategy for inorganic nanostructure synthesis. Among various chemical transformations, the cation-exchange reaction is especially interesting because it can alter the composition of the existing ionic nanocrystal by replacing the cations within the crystal lattice with a different metal ion.

The cation exchange at the nanoscale can transfer one material into another while retaining its morphology. If the exchange only takes place partially in the nanostructure, alloy or core-shell structures are formed. However, by carefully controlling the reaction, heterostructures may also be obtained. Alivisatos and co-authors ${ }^{\mathbf{1 9 1}}$ gave an example of partial change of $\mathrm{CdS}$ nanorods into $\mathrm{Ag}_{2} \mathrm{~S}$ to form CdS- $\mathrm{Ag}_{2} \mathrm{~S}$ superlattices. CdS nanorods in toluene were added to a solution containing toluene, $\mathrm{AgNO}_{3}$ and methanol at very low temperature and then warmed to room temperature slowly to allow the replacement reaction. The lattice mismatch strains induced the spontaneous

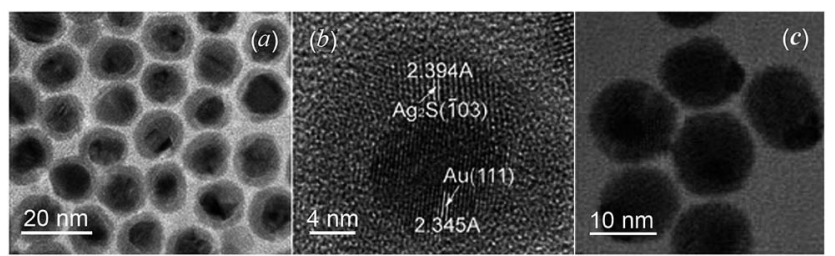

Fig. 21 (a) TEM and (b) HRTEM images of $\mathrm{Ag}_{2} \mathrm{~S} / \mathrm{Au}$ heteronanostructures, ${ }^{188}$ and (c) TEM image of $\mathrm{Ag}_{2} \mathrm{~S} / \mathrm{Ag}$ heteronanostructures. ${ }^{16}$ formation of periodic structures. The product showed an array of $\mathrm{Ag}_{2} \mathrm{~S}$ quantum dots separated by confining regions of CdS. Such an array has potential applications as nanometer-scale optoelectronic devices.

$\mathrm{Ag}_{2} \mathrm{~S} / \mathrm{ZnS}$ heteronanostructures having a matchstick shape with $\mathrm{Ag}_{2} \mathrm{~S}$ quantum dots as the heads and $\mathrm{ZnS}$ quantum rods as the stems were synthesized in study. ${ }^{192}$ These hybrid quantum rods were synthesized by a one-pot thermal decomposition method, and their size could be tuned by changing the ratio between the Ag-DDTC and zinc diethyldithiocarbamate ( $\mathrm{Zn}$ $\left[\mathrm{S}_{2} \mathrm{CN}\left(\mathrm{C}_{2} \mathrm{H}_{5}\right)_{2}\right]_{2}$ or $\left.\mathrm{Zn}(\mathrm{DDTC})_{2}\right)$ precursors. The diameter of the $\mathrm{Ag}_{2} \mathrm{~S}$ head in the $\mathrm{Ag}_{2} \mathrm{~S} / \mathrm{ZnS}$ heterostructures was around $8.5 \mathrm{~nm}$ and the stem size was $\sim 7.8 \times 35 \mathrm{~nm}$ when a $1: 2$ $\mathrm{Ag}(\mathrm{DDTC}): \mathrm{Zn}(\mathrm{DDTC})_{2}$ molar ratio was used in the synthesis. With an increased molar ratio of $2: 1$, the diameter of the $\mathrm{Ag}_{2} \mathrm{~S}$ head in the heteronanostructures was about $4.5 \mathrm{~nm}$ and the stem size was $\sim 4 \times 48 \mathrm{~nm}$ (Fig. 22). The $\mathrm{Ag}_{2} \mathrm{~S} / \mathrm{ZnS}$ heteronanostructures exhibited appealing PL in UV/blue and NIR regions. Later, Shen et al. ${ }^{43}$ modified the synthetic approach to demonstrate one-pot fabrication of Mn-doped $\mathrm{Ag}_{2} \mathrm{~S} / \mathrm{ZnS}$ quantum rods with multicolor PL in three wavelength regions (blue, orange, and NIR).

A convenient room-temperature method for preparation of a new type of $\mathrm{Ag}_{2} \mathrm{~S} / \mathrm{Ag}$ heterodimers was devised in study. ${ }^{55} \mathrm{At}$ first, monodisperse CdS colloidal nanospheres were synthesized through a modified polyol process (i.e., synthesis of
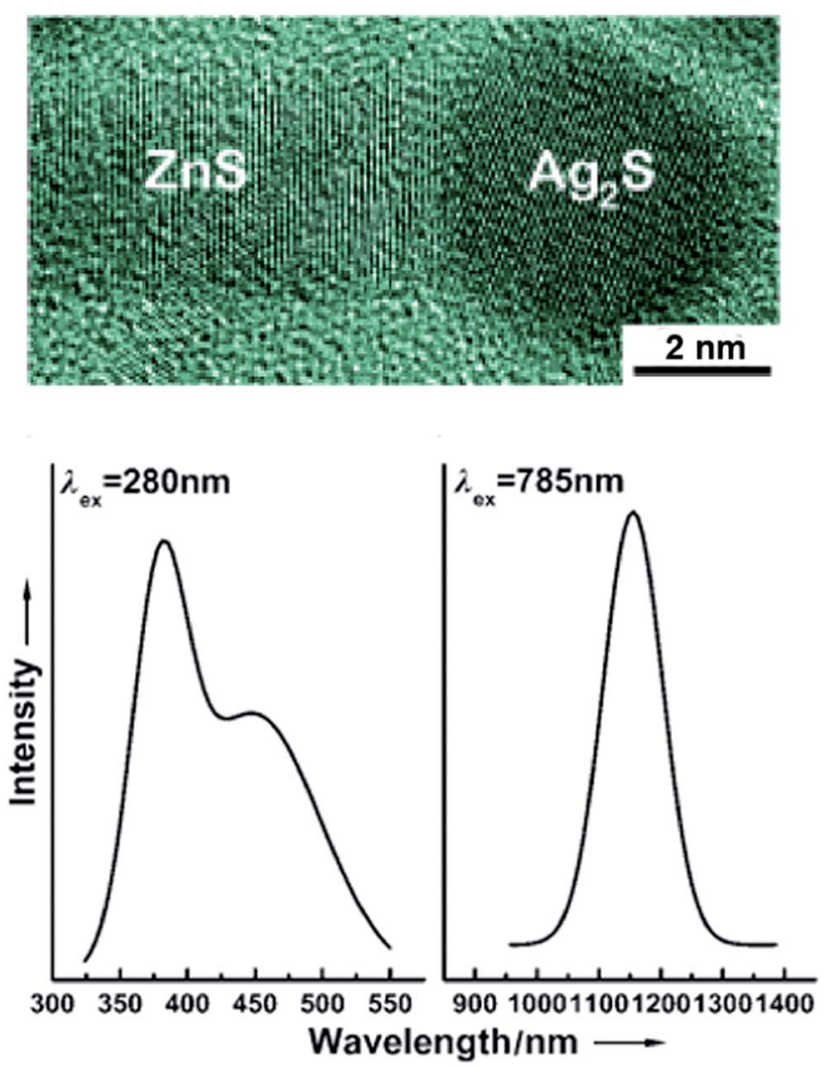

Fig. 22 HRTEM image of an $\mathrm{Ag}_{2} \mathrm{~S} / \mathrm{ZnS}$ heteronanostructure and its UV/blue and NIR photo-luminescence at 280 and $785 \mathrm{~nm}$, excitation, respectively. Reproduced from ref. 192 with permission from Wiley. 
a metal-containing compound in PEG). The CdS nanospheres were used as solid precursors for subsequent chemical transformation to $\mathrm{Ag}_{2} \mathrm{~S}$ nanospheres via cation exchange and as a template for deposition of metallic silver. As a result, each $\mathrm{Ag}_{2} \mathrm{~S}$ nanosphere was grown with a triangular prism of a $\mathrm{Ag}$ crystal, leading to formation of a novel type of asymmetric semiconductor/metal photosensitive heterodimers. According to ${ }^{55}$ these $\mathrm{Ag}_{2} \mathrm{~S} / \mathrm{Ag}$ semiconductor/metal heterodimers exhibited remarkable bactericidal activity under visible-light illumination and may find future applications, including bacterial deactivation, bioimaging and sensing, as well as heterogeneous catalysis under ambient conditions.

According to study, ${ }^{193}$ mono-dispersed $\mathrm{Ag}_{2} \mathrm{~S} @ \mathrm{Ag}$ hybrid nanocomposites exhibit superior adsorption performance for the removal of such organic contaminants as methyl blue and methyl orange from wastewater. Mono-dispersed $\mathrm{Ag}_{2} \mathrm{~S} @ \mathrm{Ag}$ nanoparticles have been synthesized using laser ablation of bulk $\mathrm{Ag}$ targets in activated aqueous solution containing $\mathrm{C}_{2} \mathrm{H}_{5} \mathrm{NS}$ and hexadecyl trimethyl ammonium bromide.

Comparison of the advantages and disadvantages of the main methods for synthesis of $\mathrm{Ag}_{2} \mathrm{~S} / \mathrm{Ag}$ heteronanostructures is presented in Table 5 .

Nonvolatile memory unit represents one of the most important components in state-of-the-art microelectronic/ nanoelectronic devices and has been subject of intensive investigations in the past decades. ${ }^{16,48-50,181,194}$ Among different concepts memories, resistive switching memories, whose operation is primarily based on ion migrations that can result in reversible formation and breakage of a conductive filament in the sandwiched metal-insulator-metal structure, are particularly intriguing because they have a low production cost, offer reduced power consumption, and a switching rate as fast as semiconductor devices currently used and, in principle, can be made arbitrarily small. The $\mathrm{Pt} / \mathrm{Ag}_{2} \mathrm{~S} / \mathrm{Ag}$ is an interesting structure exhibiting well-defined resistive switching behavior. ${ }^{181}$ For example, Aono and co-authors ${ }^{\mathbf{1 8 1 , 1 9 5}}$ demonstrated basic logic gate operations and fabricated a $1 \mathrm{kbit}$ nonvolatile memory chip based on a Pt/ $\mathrm{Ag}_{2} \mathrm{~S} / \mathrm{Ag}$ heteronanostructure. Recently, they further clarified the rate-limiting processes determining the switching time in a $\mathrm{Pt} / \mathrm{Ag}_{2} \mathrm{~S} / \mathrm{Ag}$ system, thus providing a deeper understanding toward the switching mechanism. ${ }^{\mathbf{1 9 6}}$ Despite much recent progress, for future applications, an extended array of $\mathrm{Ag}_{2} \mathrm{~S} / \mathrm{Ag}$ resistive switches with smaller feature size as well as compatibility with conventional Si-based technology would be more favorable, but has not been realized.

The semiconductor/metal $\mathrm{Ag}_{2} \mathrm{~S} / \mathrm{Ag}$ heteronanostructures are interesting for the production of resistive switches and nonvolatile memory devices.

The electrical properties of $\mathrm{Ag}_{2} \mathrm{~S} / \mathrm{Ag}$ heteronanostructure of the heteronanowire type have been studied in work. ${ }^{48}$ An anodic aluminum oxide (AAO) template-assisted electrochemical strategy was used for synthesizing a $\mathrm{Ag}_{2} \mathrm{~S} / \mathrm{Ag}$ heteronanowire array. The porous AAO membrane was deposited partially with $\mathrm{Ag}$ nanowires, and then $\mathrm{Ag}_{2} \mathrm{~S}$ nanowires were grown by electrochemical sulfurization. Liang et al. ${ }^{48}$ assumed that the main reason for the resistance-switching phenomenon in this $\mathrm{Ag}_{2} \mathrm{~S}$ / $\mathrm{Ag}$ heteronanostructure was the creation and dissolution of a filament-like $\mathrm{Ag}$ conducting bridge.

Recently, authors of study ${ }^{194}$ reported the fabrication of an extended array of $\mathrm{Ag}_{2} \mathrm{~S} / \mathrm{Ag}$ nanodots with a density of $60 \mathrm{Gbit}$ $\mathrm{in}^{-2}$, which was accomplished by sputtering $\mathrm{Ag}$ onto a $\mathrm{Si}$ substrate using an ultrathin porous AAO membrane as a shadow mask, followed by room-temperature sulfurization (Fig. 23). This resulted in the formation of a high density of $\mathrm{Ag}_{2} \mathrm{~S} / \mathrm{Ag}$ bilayer nanodots with a feature size of $45 \mathrm{~nm}$.

The resistance switching behavior of an $\mathrm{Ag} / \mathrm{Ag}_{2} \mathrm{~S} / \mathrm{W}$ nanoscale heterostructure of sandwich type was studied by Xu et al. ${ }^{\mathbf{4 9}}$ To synthesize $\mathrm{Ag}_{2} \mathrm{~S}$, an $\mathrm{Ag}$ wire of diameter of $0.5 \mathrm{~mm}$ heated with $\mathrm{S}$ powder to $470 \mathrm{~K}$ for $30 \mathrm{~min}$. The sulfidized $\mathrm{Ag}$ wire was scratched by an $\mathrm{Ag}$ wire so that some small pieces of $\mathrm{Ag}_{2} \mathrm{~S}$ were transferred to the Ag wire. For observation, the $\mathrm{Ag}$ wire with the $\mathrm{Ag}_{2} \mathrm{~S}$ tip-end was mounted on a high-resolution transmission electron microscope opposite the sharp tungsten $\mathrm{W}$ tip. $\mathrm{Xu}$ et $a .^{49}$ directly observed the formation and breakage of a conducting pathway in a superionic solid electrolyte resistance

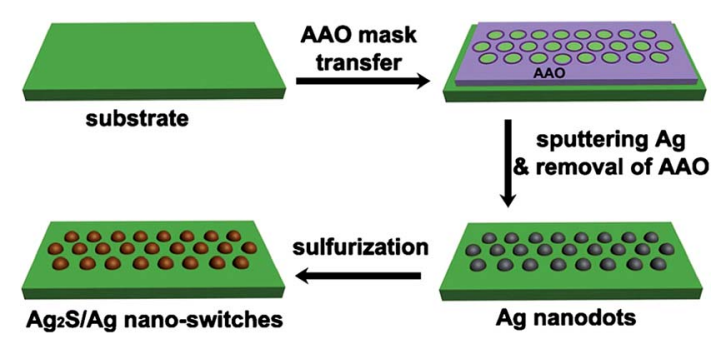

Fig. 23 Schematic illustration of the fabrication of $\mathrm{Ag}_{2} \mathrm{~S} / \mathrm{Ag}$ nanodot resistive switch arrays (AAO is anodic aluminum oxide). ${ }^{194}$

Table 5 Main methods of synthesis of $\mathrm{Ag}_{2} \mathrm{~S} / \mathrm{Ag}$ heteronanostructures

\begin{tabular}{|c|c|c|c|c|}
\hline Method & Main reagents ${ }^{a}$ & Advantages & Disadvantages & Ref. \\
\hline $\begin{array}{l}\text { Hydrothermal cation } \\
\text { exchange }\end{array}$ & $\mathrm{AgNO}_{3}, \mathrm{Na}_{2} \mathrm{~S}, \mathrm{Na}_{3} \mathrm{Cit}, \mathrm{C}_{18} \mathrm{H}_{17} \mathrm{~K}_{2} \mathrm{O}_{8} \mathrm{PS}_{2}$ & Controllable size & Complicated process & 40,189 and 190 \\
\hline Cation exchange & $\begin{array}{l}\mathrm{Cd}\left(\mathrm{NO}_{3}\right)_{2}, \mathrm{AgNO}_{3}, \mathrm{Na}_{3} \mathrm{Cit},\left(\mathrm{NH}_{2}\right)_{2} \mathrm{CS} \\
\mathrm{C}_{2} \mathrm{H}_{5} \mathrm{OH}, \mathrm{C}_{3} \mathrm{H}_{6} \mathrm{O}, \mathrm{PVP}\end{array}$ & Controllable size & Complicated sequential process & 55 \\
\hline Laser ablation & $\mathrm{Ag}, \mathrm{C}_{2} \mathrm{H}_{5} \mathrm{NS}, \mathrm{C}_{16} \mathrm{H}_{33} \mathrm{~N}\left(\mathrm{CH}_{3}\right)_{3} \mathrm{Br}$ & Controllable size & Complicated operation, high cost & 193 \\
\hline $\begin{array}{l}\text { Hydrochemical } \\
\text { deposition }\end{array}$ & $\mathrm{AgNO}_{3}, \mathrm{Na}_{2} \mathrm{~S}, \mathrm{Na}_{3} \mathrm{Cit}$ & $\begin{array}{l}\text { Controllable size, } \\
\text { non-toxic reagents, safety }\end{array}$ & Low yield & 195 and 200 \\
\hline
\end{tabular}




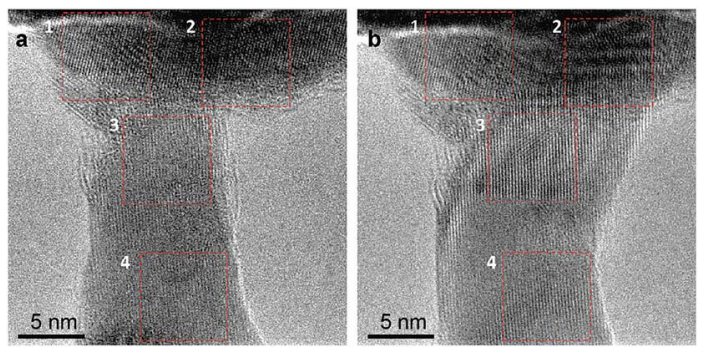

Fig. 24 (a) Off- and (b) on-states of a narrow and thin $\mathrm{Ag}_{2} \mathrm{~S} / \mathrm{Ag}$ device regions. The $\mathrm{Ag}$ electrode is located on the top part of the image, and the $\mathrm{W}$ electrode is in the bottom part. When the device is switched from the off- to on-states, an area 1 has almost no change, the argentite appears in area 2, the argentite and Ag appear in area 3, and no changes are seen in area 4. Reproduced from ref. 49 with permission from ACS.

nanoswitch with complete reproduction of its performance (Fig. 24). They found that the transition of semiconducting acanthite $\alpha-\mathrm{Ag}_{2} \mathrm{~S}$ into conducting argentite $\beta-\mathrm{Ag}_{2} \mathrm{~S}$ took place at room temperature and only within a conductive pathway. The argentite not only formed part of the conducting channel but also provided the pathway for the migration of $\mathrm{Ag}^{+}$. In fact, the $\mathrm{Ag}^{+}$could migrate only in the argentite phase and not in the acanthite $\alpha-\mathrm{Ag}_{2} \mathrm{~S}$ phase.

In study, ${ }^{197}$ a wet chemical process was used for fabrication of $\mathrm{Ag}_{2} \mathrm{~S}$ flat thin films on $\mathrm{Ag}$ electrodes utilized for an atomic $\mathrm{Ag}_{2} \mathrm{~S} / \mathrm{Ag}$ switch. A counter electrode made of $\mathrm{Ag}$ with a gap of $\sim 1$ $\mu \mathrm{m}$ was fabricated using conventional UV-lithography on a $\mathrm{Si}$ substrate. The substrate with $\mathrm{Ag}$ was dipped into an aqueous solution of $\mathrm{Na}_{2} \mathrm{~S}$ for sulfurization. As a result, $\mathrm{Ag}_{2} \mathrm{~S}$ was formed on the Ag surface.

In study, ${ }^{50}$ the resistive switches $\mathrm{Ag}_{2} \mathrm{~S} / \mathrm{Ag}$ nanoclusters for memory cells were formed by sulfurization of melting-dispersed thin continuous Ag films. Ag nanocluster arrays were formed by thermal annealing of $10 \mathrm{~nm}$-thick $\mathrm{Ag}$ films at $500 \mathrm{~K}$ during $40 \mathrm{~min}$ immediately after vacuum thermal evaporation. Lowtemperature sulfurization in $\mathrm{a}_{2} \mathrm{~S}$ atmosphere in an airtight chamber was used to obtain $\mathrm{Ag}_{2} \mathrm{~S}$ particles.

Gubicza et al. ${ }^{198}$ demonstrated stable resistive switchings in metallic $\mathrm{Ag}-\mathrm{Ag}_{2} \mathrm{~S}-\mathrm{Ag}$ heteronanojunctions created by an scanning tunneling microscope (STM). An $80 \mathrm{~nm}$-thick Ag layer was deposited onto a Si substrate followed by a 5 min sulfurization in a $\mathrm{H}_{2} \mathrm{~S}$ atmosphere at $333 \mathrm{~K}$. As a result, a $30 \mathrm{~nm}$-thick stoichiometric $\mathrm{Ag}_{2} \mathrm{~S}$ cap layer on the planar $\mathrm{Ag}$ electrode was obtained. Nanometer-scale junctions were created between the $\mathrm{Ag}_{2} \mathrm{~S}$ surface and a mechanically sharpened $\mathrm{Ag}$ wire of $0.35 \mathrm{~mm}$ in diameter in STM geometry. According to,${ }^{198}$ fast and highly integrable memory cells are the merits of lithographically designed $\mathrm{Ag}-\mathrm{Ag}_{2} \mathrm{~S}-\mathrm{Ag}$ heteronanostructures.

The synthesis of multifunctional nanocomposite systems is of great interest. In particular, heteronanostructures such as $\mathrm{Ag}_{2} \mathrm{~S} / \mathrm{Ag}$ consisting of a semiconductor and a noble metal are very useful for various applications. This type of heterostructures that contain $\mathrm{Ag}$ and $\mathrm{Ag}_{2} \mathrm{~S}$ nanowires or an $\mathrm{Ag}$ film with $\mathrm{Ag}_{2} \mathrm{~S} / \mathrm{Ag}$ nanoclusters are considered for the production of biosensors, ${ }^{183}$ resistive switches, and nonvolatile memory devices. ${ }^{4-50,194,197,199}$ The action of the resistive switch is based on the phase transformation between nonconducting $\alpha-\mathrm{Ag}_{2} \mathrm{~S}$ acanthite and superionic $\beta-\mathrm{Ag}_{2} \mathrm{~S}$ argentite.

Hydrochemical deposition has been applied for the first time to the synthesis of $\mathrm{Ag}_{2} \mathrm{~S} / \mathrm{Ag}$ heteronanostructures in studies. ${ }^{136,200-203} \quad \mathrm{Ag}_{2} \mathrm{~S} / \mathrm{Ag}$ heteronanostructures have been synthesized by chemical deposition from aqueous solutions of $\mathrm{AgNO}_{3}, \mathrm{Na}_{2} \mathrm{~S}$, and $\mathrm{Na}_{3} \mathrm{Cit}$ with a reduced concentration of $\mathrm{Na}_{2} \mathrm{~S}$ $\left(C_{\mathrm{Na}_{2} \mathrm{~S}}<C_{\mathrm{AgNO}_{3}} / 2\right)$. Synthesis was carried out under illumination of solutions by a light-emitting diode with a $450 \mathrm{~nm}$ wavelength and an irradiation intensity of $15 \mathrm{~mW} \mathrm{~cm} \mathrm{~cm}^{-2}$. Two processes take place simultaneously in such mixtures: formation of $\mathrm{Ag}_{2} \mathrm{~S}$ and appearance of $\mathrm{Ag}$ nanoparticles as a result of photochemical reduction reaction (6) of $\mathrm{Ag}^{2+}$ by $\mathrm{C}_{6} \mathrm{H}_{5} \mathrm{O}_{7}{ }^{3-}$. At certain synthesis conditions, $\mathrm{Ag}$ and $\mathrm{Ag}_{2} \mathrm{~S}$ nanoparticles are united in $\mathrm{Ag}_{2} \mathrm{~S} / \mathrm{Ag}$ nanocomposites.

The scheme of deposition of $\mathrm{Ag}_{2} \mathrm{~S} / \mathrm{Ag}$ heteronanostructures from aqueous solutions of $\mathrm{AgNO}_{3}, \mathrm{Na}_{2} \mathrm{~S}$ and $\mathrm{Na}_{3} \mathrm{Cit}$, TEM and HRTEM images of $\mathrm{Ag}_{2} \mathrm{~S}, \mathrm{Ag}$ and $\mathrm{Ag}_{2} \mathrm{~S} / \mathrm{Ag}$ particles and their diffraction patterns, as well as EDX analysis of $\mathrm{Ag}_{2} \mathrm{~S}$, $\mathrm{Ag}$ particles and $\mathrm{Ag}_{2} \mathrm{~S} / \mathrm{Ag}$ heteronanostructures are shown in Fig. 25.

Synthesis was carried out in a particular sequence. Briefly, a complexing agent was added to $\mathrm{AgNO}_{3}$ in the dark. Then, a solution of $\mathrm{Na}_{2} \mathrm{~S}$ was poured into the prepared solution (Fig. 25a). As a result, deposition of $\mathrm{Ag}_{2} \mathrm{~S}$ powder occurred. Then, the solution was irradiated with monochromatic light at wavelength $450 \mathrm{~nm}$. In accordance with the photochemical reaction (6) $\mathrm{C}_{6} \mathrm{H}_{5} \mathrm{O}_{7}{ }^{3-}$ reduced the $\mathrm{Ag}^{+}$to $\mathrm{Ag}$ nanoparticles in aqueous solutions (Fig. 25b). The reduction of $\mathrm{Ag}$ at the surface of $\mathrm{Ag}_{2} \mathrm{~S}$ nanoparticles leads to the formation of $\mathrm{Ag}_{2} \mathrm{~S} / \mathrm{Ag}$ heteronanostructures (Fig. 25c).

The HRTEM images of deposited $\mathrm{Ag}_{2} \mathrm{~S}, \mathrm{Ag}$ and $\mathrm{Ag}_{2} \mathrm{~S} / \mathrm{Ag}$ particles are shown in Fig. 25d-f, respectively. In studies, ${ }^{\mathbf{1 3 6 , 2 0 0 , 2 0 1 , 2 0 3}}$ the diffraction patterns (selected area of electron diffraction (SAED)) (Fig. 25g-i) of these particles were obtained by fast Fourier transformation (FFT) of their HRTEM images.

The observed set (Fig. 25g) of diffraction reflections and interplanar distances of $\mathrm{Ag}_{2} \mathrm{~S}$ nanoparticles corresponded to monoclinic (space group $P 2_{1} / c$ ) nanocrystalline acanthite $\alpha$ $\mathrm{Ag}_{1.93} \mathrm{~S} .{ }^{148}$ The $\mathrm{Ag}$ nanoparticle (Fig. 25e) had a cubic (space group $F m \overline{3} m$ ) structure with microtwinning in the direction of the [111] planes (Fig. 25h). Diffraction patterns (Fig. 25i) obtained by FFT of HRTEM images (Fig. 25f) of $\mathrm{Ag}_{2} \mathrm{~S} / \mathrm{Ag}$ heteronanostructures revealed reflections of monoclinic $\mathrm{Ag}_{2} \mathrm{~S}$ and twinned reflections of cubic Ag.

According to the EDX results (Fig. 25j-l), the content of $\mathrm{Ag}$ and $\mathrm{S}$ in $\mathrm{Ag}_{2} \mathrm{~S}$ nanoparticles was $\sim 86.3 \pm 0.4$ and $\sim 12.9 \pm 0.1$ wt $\%$ and corresponded to $\sim \mathrm{Ag}_{1.95-1.98} \mathrm{~S}$. Ag nanoparticles contained $\mathrm{Ag}$ only, and $\mathrm{Ag}_{2} \mathrm{~S} / \mathrm{Ag}$ heteronanostructure contained about 87.8 and $11.5 \mathrm{wt} \%$ of $\mathrm{Ag}$ and $\mathrm{S}$, respectively.

The XRD pattern and HRTEM images of $\mathrm{Ag}_{2} \mathrm{~S} / \mathrm{Ag}$ heteronanostructures are shown in Fig. 26. Areas (1) and (3) correspond to $\mathrm{Ag}$ and $\mathrm{Ag}_{2} \mathrm{~S}$ nanoparticles, respectively. The $\mathrm{Ag}$ nanoparticle clearly exhibited microtwinning in the direction of the $[01-1]$ planes. Area (2) corresponded to that part of heteronanostructure where the $\mathrm{Ag}_{2} \mathrm{~S}$ and $\mathrm{Ag}$ nanoparticles are in 

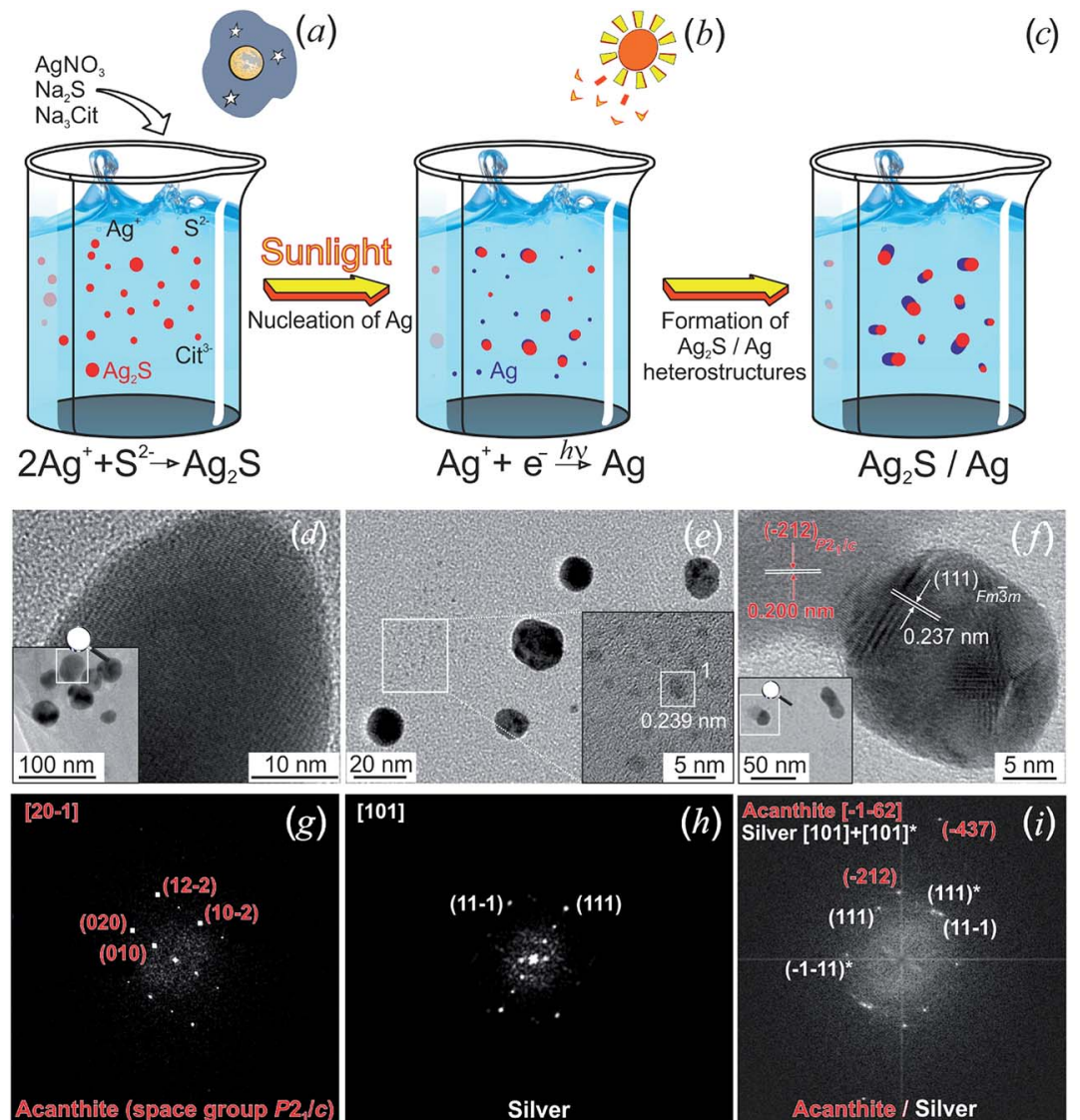

(h)
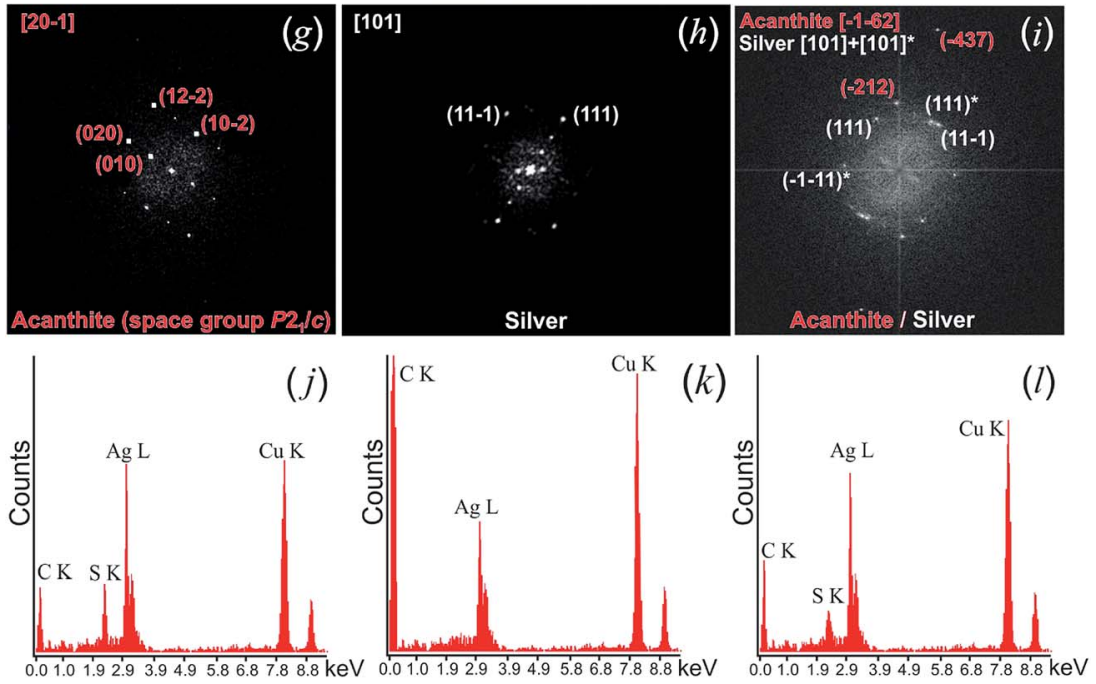

Fig. 25 Hydrochemical bath deposition of $\mathrm{Ag}_{2} \mathrm{~S} / \mathrm{Ag}$ heteronanostructures. (First row) scheme of deposition. (Second row) TEM and HRTEM images of (d) $\mathrm{Ag}_{2} \mathrm{~S}$ nanoparticles, (e) Ag nanoparticles, and (f) $\mathrm{Ag}_{2} \mathrm{~S} / \mathrm{Ag}$ heteronanostructures. (Third row) FFT patterns (g), (h), and (i) obtained from the (d), (e), and (f) HRTEM images, respectively. (Fourth row) EDX analysis of (j) $\mathrm{Ag}_{2} \mathrm{~S}$ nanoparticle, (k) Ag nanoparticle, and (l) $\mathrm{Ag}{ }_{2} \mathrm{~S} / \mathrm{Ag}$ heteronanostructure. Reproduced from ref. 200 with permission of Springer.

direct contact. Indeed, a set of spots (Fig. 26b) contains diffraction reflections of both phases: $\mathrm{Ag}_{2} \mathrm{~S}$ and $\mathrm{Ag}$. The interplanar distances for area (3) and the set of eight spots (Fig. 26c) corresponded to monoclinic (space group $P 2_{1} / c$ ) $\quad \alpha-\mathrm{Ag}_{2} \mathrm{~S}$ acanthite.

The $\mathrm{Ag}_{2} \mathrm{~S} / \mathrm{Ag}$ heteronanostructures combine ionic and electronic conductors and can be used to create biosensors, resistive switches and nonvolatile memory devices.

Let us turn to a discussion of $\mathrm{Ag}_{2} \mathrm{~S} / \mathrm{Ag}$ heteronanostructures prepared by the hydrochemical deposition method.

A typical $\mathrm{Ag}_{2} \mathrm{~S} / \mathrm{Ag}$ heteronanostructure contained in the colloidal solution prepared from aqueous solutions of $\mathrm{AgNO}_{3}$, $\mathrm{Na}_{2} \mathrm{~S}$ and $\mathrm{Na}_{3}$ Cit is shown in Fig. 27 as an example. As can be seen, the $\mathrm{Ag}_{2} \mathrm{~S}$ and $\mathrm{Ag}$ nanoparticles are in immediate contact. The Ag nanoparticle clearly exhibits microtwinning in the direction of the [111] planes. According to the EDX data, the nanoparticle contains only Ag. The interplanar distances observed for $\mathrm{Ag}_{2} \mathrm{~S}$ nanoparticles correspond to monoclinic acanthite. The zone axis of the $\mathrm{Ag}_{2} \mathrm{~S}$ nanoparticle matrix is $[101]_{P 2_{1} / c}$.

The resistive switches of $\mathrm{Ag}_{2} \mathrm{~S} / \mathrm{Ag}$ types consist of a superionic conductor located between two metal electrodes. In the case of $\mathrm{Ag}_{2} \mathrm{~S} / \mathrm{Ag}$ heterostructures, one of the electrodes is $\mathrm{Ag}$, and the second electrode can be $\mathrm{Pt}, \mathrm{Au}, \mathrm{Cu}$, or $\mathrm{W}$. The conductivity of Ag was $6.3 \times 10^{5} \mathrm{ohm}^{-1} \mathrm{~cm}^{-1}$, that of the $\beta-\mathrm{Ag}_{2} \mathrm{~S}$ argentite and $\alpha-\mathrm{Ag}_{2} \mathrm{~S}$ acanthite phases were about $1.6 \times 10^{3}$ and only $2.5 \times 10^{-3} \mathrm{ohm}^{-1} \mathrm{~cm}^{-1}$ at room temperature, ${ }^{35}$ respectively. Thus, the conductivity of acanthite was 6 orders of magnitude lower than that for the argentite phase. It is, thus, reasonable to conclude that the conducting channel in $\mathrm{Ag}_{2} \mathrm{~S} / \mathrm{Ag}$ heterostructures can be made of a mixture of $\mathrm{Ag}$ and $\beta-\mathrm{Ag}_{2} \mathrm{~S}$ argentite. 


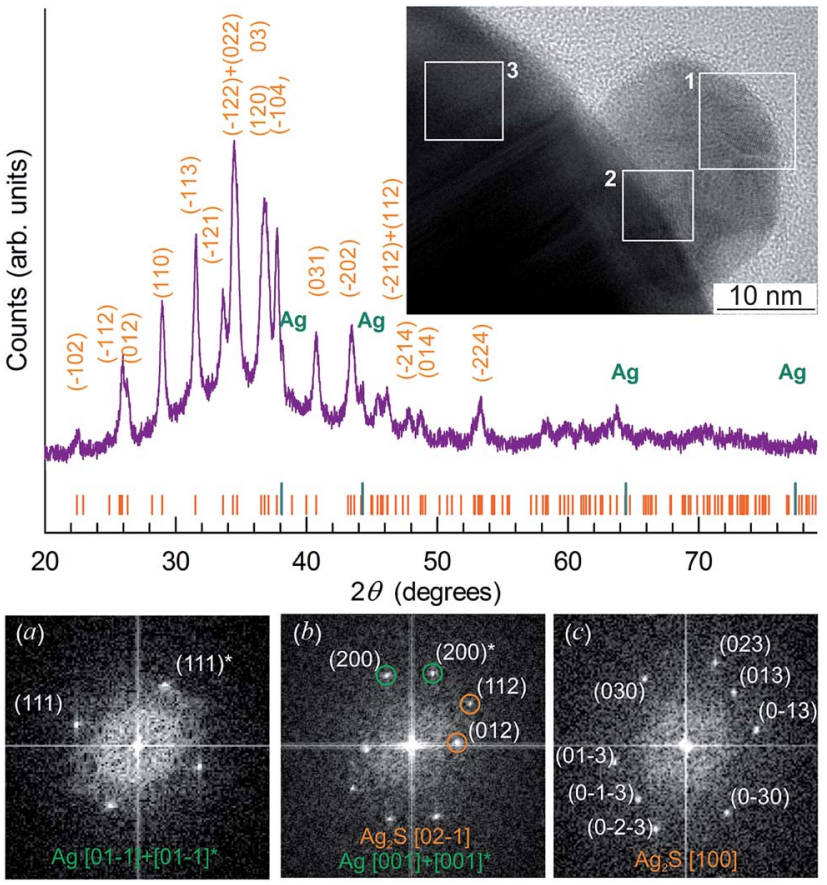

Fig. 26 The XRD pattern and HRTEM image of $\mathrm{Ag}_{2} \mathrm{~S} / \mathrm{Ag}$ heteronanostructures. The long and short ticks on XRD patterns correspond to reflections of cubic metallic $\mathrm{Ag}$ and monoclinic $\mathrm{Ag}_{2} \mathrm{~S}$, respectively. The areas (1) and (3) isolated by a white square correspond to $\mathrm{Ag}$ and $\mathrm{Ag}_{2} \mathrm{~S}$, respectively. Area (2) corresponds to the region where the $\mathrm{Ag}_{2} \mathrm{~S}$ and Ag nanoparticles are in direct contact. (a), (b), and (c) Selected areas of electron diffraction obtained by FFT of areas (1), (2), and (3) of heteronanostructure. Twinned reflections of silver are marked by *. Reproduced from ref. 200 with permission of Springer.

In studies, ${ }^{136,200-203} \mathrm{Ag}_{2} \mathrm{~S} / \mathrm{Ag}$ heteronanostructures formed by $\mathrm{Ag}_{2} \mathrm{~S}$ and $\mathrm{Ag}$ nanoparticles were produced by a simple method of hydrochemical bath deposition. Deposition of $\mathrm{Ag}_{2} \mathrm{~S} / \mathrm{Ag}$

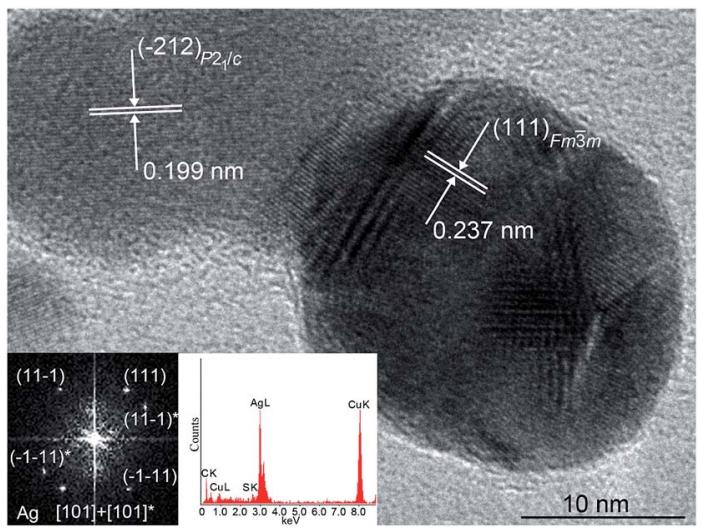

Fig. 27 HRTEM image of $\mathrm{Ag}_{2} \mathrm{~S} / \mathrm{Ag}$ heteronanostructures. Monoclinic (space group $P 2_{1} / C$ ) $A_{2} S$ nanoparticle with an $\alpha-A_{2} S$ acanthite structure (upper left corner) is in direct contact with a cubic (space group $\mathrm{Fm} 3 \mathrm{~m}$ ) Ag nanoparticle. The electron diffraction pattern obtained by FFT of the HRTEM image of an Ag nanoparticle, and cumulative elemental EDX pattern of this Ag nanoparticle, are shown (lower left corner). Twinned reflections of silver are marked by *, zone axes are [101] + [101]*. Reproduced from ref. 136 with permission from Wiley. heterostructures on a substrate coated with a thin conducting metallic layer will make it possible to form a structure that can work as a resistive switch. The action of the switch is based on the phase transformation of nonconducting $\alpha-\mathrm{Ag}_{2} \mathrm{~S}$ acanthite into $\beta-\mathrm{Ag}_{2} \mathrm{~S}$ argentite exhibiting superionic conduction. The transition into a high-conduction state is due to abrupt disordering of the cationic sublattice. Authors of studies ${ }^{\mathbf{2 0 4 , 2 0 5}}$ have shown that a high-conduction state of a crystal can be achieved by external electric field-induced "melting" of the cationic sublattice taking place without heating of the crystal. Such transformation occurring as a result of applied external electric field was confirmed with respect to nanocrystalline $\mathrm{Ag}_{2} \mathrm{~S}$ in studies. ${ }^{49,50,194,199}$ The effect of an external electric field induced abrupt disordering, allowing the realization of the superionic state of $\mathrm{Ag}_{2} \mathrm{~S}$ at room temperature. This opens up the possibilities for the practical use of materials based on $\mathrm{Ag}_{2} \mathrm{~S}$.

Authors of works ${ }^{200-203}$ studied preliminarily the switching processes in $\mathrm{Ag}_{2} \mathrm{~S} / \mathrm{Ag}$ heteronanostructures. For this purpose, a metallic Pt microcontact was supplied to $\mathrm{Ag}_{2} \mathrm{~S} / \mathrm{Ag}$ heteronanostructure and bias voltage was impressed so that the $\mathrm{Ag}$ electrode was charged positively. When positive bias voltage increased to $500 \mathrm{mV}$, the conduction of the heteronanostructure grew and the nanodevice transformed into the conducting state (i.e., the on-state). The bias back to negative values decreased the conduction and the nanodevice transformed into the offstate.

Fig. 28 displays a region of an $\mathrm{Ag}_{2} \mathrm{~S} / \mathrm{Ag}$ heteronanostructure where change of crystal structure at the transition from the offstate (Fig. 28a) to the on-state (Fig. 28b) can be observed. Using FFT of HRTEM images, authors of studies ${ }^{\mathbf{2 0 0 , 2 0 2 , 2 0 3}}$ obtained the selected areas of electron diffraction (SAEDs) (Fig. 28c and d).

The electron diffraction pattern of an $\mathrm{Ag}_{2} \mathrm{~S} / \mathrm{Ag}$ heteronanostructure in the off-state is shown in Fig. 28c. This SAED contains (111), (11-1) spots and twinning reflection (111)* corresponding to cubic (space group $F m \overline{3} m$ ) Ag, as well as $(2-12)$ and (030) spots corresponding to monoclinic (space group $\left.P 2_{1} / c\right) \alpha-\mathrm{Ag}_{2} \mathrm{~S}$ acanthite. The observed angle of $100.3^{\circ}$ between $(2-12)$ and (030) spots of monoclinic acanthite coincided within the measurement error with the theoretical value $100.7^{\circ}$. Experimental angles between diffraction spots of cubic Ag coincided with the theoretical values.

Then, a positive bias was applied to the $\mathrm{Ag}_{2} \mathrm{~S} / \mathrm{Ag}$ heteronanostructure to turn it on. HRTEM images of an $\mathrm{Ag}_{2} \mathrm{~S} / \mathrm{Ag}$ heteronanostructure in the on-state and its selected electron diffraction patterns are presented in Fig. $28 \mathrm{~b}$ and d, respectively. The electron diffraction pattern (Fig. 28d) contains two sets of spots corresponding to cubic (space group $F m \overline{3} m$ ) Ag, and cubic (space group $\operatorname{Im} \overline{3} m$ ) $\beta-\mathrm{Ag}_{2} \mathrm{~S}$ argentite. The observed angle of $30.1^{\circ}$ between the (011) and (112) spots of cubic $\beta-\mathrm{Ag}_{2} \mathrm{~S}$ argentite coincides with the theoretical value of $30^{\circ}$.

Thus, the applied bias leads to the appearance of conducting $\beta-\mathrm{Ag}_{2} \mathrm{~S}$ argentite instead of nonconducting $\alpha-\mathrm{Ag}_{2} \mathrm{~S}$ acanthite and the formation of conductive channel from argentite $\beta-\mathrm{Ag}_{2} \mathrm{~S}$ and Ag.

The current-voltage $I(V)$ characteristics of the resistive switches based on $\mathrm{Ag}_{2} \mathrm{~S} / \mathrm{Ag}$ heteronanostructures produced by different methods are presented in studies. ${ }^{48-50,194,199}$ As a rule, 

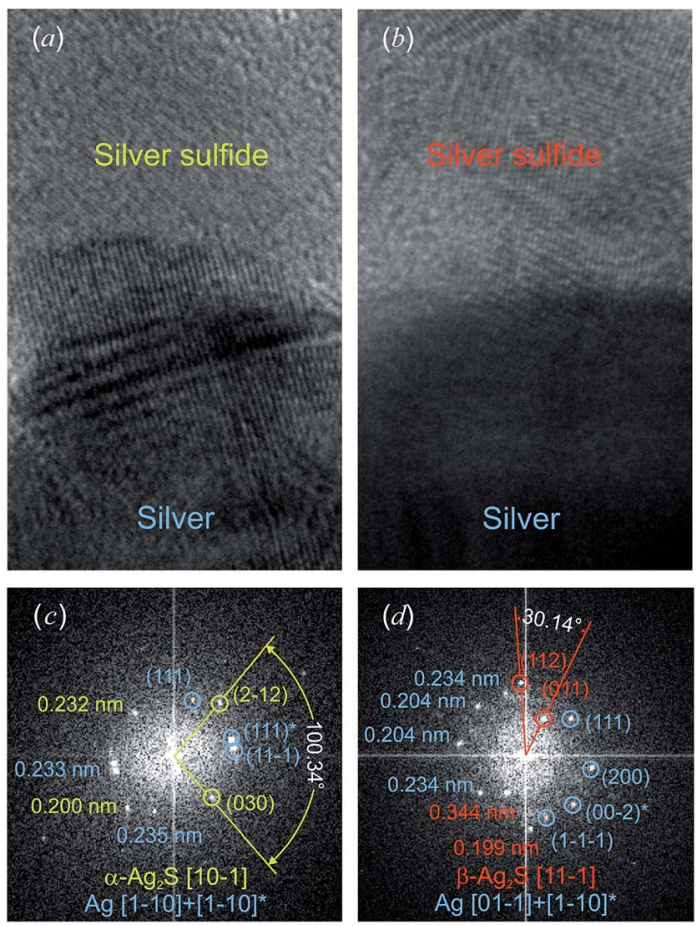

Fig. 28 HRTEM images of the region of transition between $\mathrm{Ag}$ and $\mathrm{Ag}_{2} \mathrm{~S}$ for the (a) off-state and (b) on-state of $\mathrm{Ag}_{2} \mathrm{~S} / \mathrm{Ag}$ heteronanostructures. The on-state arises as a result of applied external positive bias voltage to this $\mathrm{Ag}_{2} \mathrm{~S} / \mathrm{Ag}$ heteronanostructure. The Pt electrode is located on the top part of the image, and the Ag electrode is in the bottom part. Electron diffraction patterns (c) and (d) are obtained by FFT of HRTEM images (a) and (b), respectively. Reproduced from ref. 200 with permission of Springer.

the bias voltage is from \pm 150 to $\pm 500 \mathrm{mV}$. According to, ${ }^{49}$ the minimum energy barrier for an $\mathrm{Ag}$ cation jumping from one atomic site to the other is about $130 \mathrm{meV}$.

An $I(V)$ characteristic of the resistive switch based on an $\mathrm{Ag}_{2} \mathrm{~S} / \mathrm{Ag}$ heteronanostructure produced by hydrochemical deposition in studies ${ }^{\mathbf{2 0 0 , 2 0 2 , 2 0 3}}$ is shown in Fig. 29a. The schematic operation of this switch is shown in Fig. 29.

The initial $\mathrm{Ag}_{2} \mathrm{~S}$ phase was a nonconducting acanthite $\alpha$ $\mathrm{Ag}_{2} \mathrm{~S}$ (Fig. 29(1)). When a positive bias was applied, $\mathrm{Ag}^{+}$started to move towards the negatively charged cathode $\mathrm{M}$ and were reduced to Ag during their transport. Simultaneously, the $\alpha-\mathrm{Ag}_{2} \mathrm{~S}$ phase transformed into superionic $\beta-\mathrm{Ag}_{2} \mathrm{~S}$ argentite (Fig. 29(2)), and a continuous conductive channel was formed (Fig. 29(3)). The continuous conductive channel that was formed from argentite $\beta-\mathrm{Ag}_{2} \mathrm{~S}$ and $\mathrm{Ag}$ was retained when the external field is turned off. This phenomenon can be considered to be a memory effect (Fig. 29(3)). If a negative (reverse) bias is applied to the switch, the Ag nanocrystals start dissolving in argentite, the $\mathrm{Ag}^{+}$ move to the anode, argentite transforms into the initial acanthite again, the conductive channel breaks down, and an off-state is realized (Fig. 29(4 and 5)). Because of the formation of nonconducting acanthite, the conductive channel disappears, the switch transforms into the initial state and is turned off (Fig. 29(6)). If positive bias is applied once again, the destroyed conductive channel is restored due to the appearance of argentite and the formation of Ag.

According to, ${ }^{49,50,202,203}$ the bias voltage which is sufficient to turn on and turn off the switch is from \pm 0.2 to $\pm 10.0 \mathrm{~V}$ depending on the metal $\mathrm{M}$ used as the second electrode.

The UV-vis optical absorption spectra of colloidal solutions containing $\mathrm{Ag}_{2} \mathrm{~S} / \mathrm{Ag}$ composite nanoparticles ${ }^{200}$ contain a broad intensive absorption band in the region of $\sim 360$ to $450 \mathrm{~nm}$, which corresponds to $\mathrm{Ag}$ nanoparticles and is due to surface plasmon resonance (SPR). ${ }^{55,100,206,207}$ Also, the weakly diffused absorption peak observed at $\sim 312-320 \mathrm{~nm}$ corresponds to $\mathrm{Ag}_{2} \mathrm{~S}$ nanoparticles.

$\mathrm{Ag}_{2} \mathrm{~S} / \mathrm{Ag}$ nanocomposites can be applied as promising biosensing probes. Ag nanoparticles can be used as biosensors owing to their unique SPR, which depends on the size and shape of particles. ${ }^{\mathbf{1 8 3 , 2 0 8 , 2 0 9}}$ However, Ag nanoparticles are easily oxidized, which is why they should be protected. The combination of $\mathrm{Ag}$ nanoparticles and chemically stable $\mathrm{Ag}_{2} \mathrm{~S}$ allows one to increase the stability of $\mathrm{Ag}$ nanoparticles and to use $\mathrm{Ag}_{2} \mathrm{~S} / \mathrm{Ag}$ nanocomposites and $\mathrm{Ag} @ \mathrm{Ag}_{2} \mathrm{~S}$ core-shell structures for biosensing applications in the future.

According to, ${ }^{186,210} \mathrm{Ag}_{2} \mathrm{~S} / \mathrm{Ag}$ heteronanostructures possess considerable antibacterial activity and can be used in biology and medicine. This agrees with data ${ }^{54,55,144}$ on the antibacterial activity of $\mathrm{Ag}_{2} \mathrm{~S}$ colloidal solutions and nanopowders.
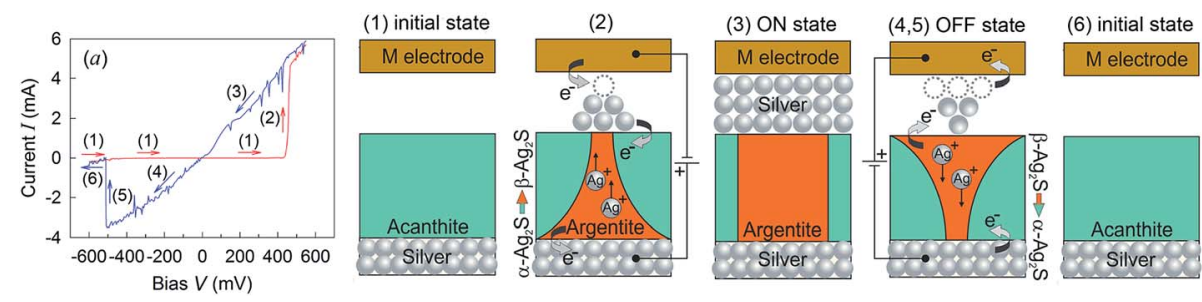

Fig. 29 Generalized scheme of the operation of an $\mathrm{Ag}_{2} \mathrm{~S} / \mathrm{Ag}$ heteronanostructure-based switch: (a) typical current-voltage characteristic of the switching; (1) initial nonconducting state; (2) the appearance of a conductive channel upon the application of an external electric field that induces the transformation of acanthite $\alpha-\mathrm{Ag}_{2} \mathrm{~S}$ into argentite $\beta-\mathrm{Ag}_{2} \mathrm{~S}$; (3) work on-state with a continuous conductive channel formed from argentite $\beta-\mathrm{Ag}_{2} \mathrm{~S}$ and $\mathrm{Ag} ;(4,5)$ off-state and breakdown of the conductive channel upon the application of negative bias and the transformation of argentite into initially acanthite; (6) initial nonconducting state after disappearance of the conductive channel and turning-off of the switch. $M$ is the metal electrode. The numbers from 1 to 6 for different states of switching correspond to the order of the events on (a) current-voltage characteristics. Reprinted from ref. 202 with permission from Elsevier. 


\section{Conclusions and outlook}

This review presented the major advances in the controlled synthesis of nanostructured $\mathrm{Ag}_{2} \mathrm{~S}$ in the form of nanopowders, stable colloidal solutions, quantum dots, isolated nanoparticles with a protective shell, and heteronanostructures. Also, the main results on the study of crystal structure, nonstoichiometry and properties of nanostructured $\mathrm{Ag}_{2} \mathrm{~S}$ were detailed.

An increasing variety of semiconductor nanostructured $\mathrm{Ag}_{2} \mathrm{~S}$ with various sizes and shapes can now be prepared. Along with the development of synthetic methods, the applications of nanostructured $\mathrm{Ag}_{2} \mathrm{~S}$ have become wider.

Investigations over recent years have shown that nanostructured materials based on $\mathrm{Ag}_{2} \mathrm{~S}$ are more effective than their bulk counterparts due to the following advantages: higher specific surface areas and more active sites for catalysis; longer cycle life; enhanced band gap of the semiconductor $\mathrm{Ag}_{2} \mathrm{~S}$ phase; higher electric conductivity of high-temperature $\mathrm{Ag}_{2} \mathrm{~S}$ phases; shorter path lengths for the transport of charge carriers (electrons and holes). Experimental studies of the quantum confinement effect of $\mathrm{Ag}_{2} \mathrm{~S}$ quantum dots have shown that the exciton diameter of $\mathrm{Ag}_{2} \mathrm{~S}$ is about $4 \mathrm{~nm}$.

Synthesized forms of nanostructured $\mathrm{Ag}_{2} \mathrm{~S}$ have several possible applications. First, stable $\mathrm{Ag}_{2} \mathrm{~S}$ colloidal solutions and $\mathrm{Ag}_{2} \mathrm{~S}$ quantum dots are suitable for biological and medical application as biomarkers because these solutions are non-toxic and do not contain hazardous substances. $\mathrm{Ag}_{2} \mathrm{~S}$ quantum dots exhibit bright photoluminescence and excellent photostability. Therefore, $\mathrm{Ag}_{2} \mathrm{~S}$ quantum dots of size less than $3-4 \mathrm{~nm}$ could be used for NIR applications in the biomedical field as luminophores or biomarkers. The creation of a protective shell on $\mathrm{Ag}_{2} \mathrm{~S}$ quantum dots helps to prevent the agglomeration and growth of quantum dots and to retain their optical properties.

Nanocrystalline $\mathrm{Ag}_{2} \mathrm{~S}$ powders can be used for production of electronic devices such as photovoltaic cells, photoconductors, and infrared detectors.

$\mathrm{Ag}_{2} \mathrm{~S} / \mathrm{Ag}$ heteronanostructures unite ionic and electronic conductors. A high-conducting state of such heteronanostructures can be induced by an external electric field without heating of this composite owing to phase transformation of nonconducting acanthite into argentite and the exhibition of superionic conduction. $\mathrm{Ag}_{2} \mathrm{~S} / \mathrm{Ag}$ heteronanostructures are intended for application in fast-acting resistive switches and nonvolatile memory devices. Also, $\mathrm{Ag}_{2} \mathrm{~S} /$ $\mathrm{Ag}$ nanocomposites can be applied as promising biosensing probes and photocatalysts. Composite heteronanostructures based on $\mathrm{Ag}_{2} \mathrm{~S}$ not only combine the properties of the individual nanocrystals, but also lead to new collective properties due to synergetic effects. Recent studies have shown that the synergetic effect can considerably enhance the properties of composite nanomaterials based on nanostructured $\mathrm{Ag}_{2} \mathrm{~S}$.

All the forms of nanostructured $\mathrm{Ag}_{2} \mathrm{~S}$ possess significant potential antibacterial activity, and can be used as effective agents against asepsis and for disinfection.

Thus, recent advances have shown that nanostructured $\mathrm{Ag}_{2} \mathrm{~S}$ possesses great possibilities for potential application in different areas, from optoelectronics to biomedicine, because of its unique physical and chemical properties and "nanosized" effects.

The exploration and development of new synthetic methods and techniques to prepare nanostructured $\mathrm{Ag}_{2} \mathrm{~S}$ with better performance, and understanding of its structure-related properties, is an ongoing task for researchers.

Although the last decade has witnessed great progress in the synthesis of nanostructured $\mathrm{Ag}_{2} \mathrm{~S}$ and its application, challenges still exist. The discussion below illustrates some of the challenges that scientists and technologists are facing in the synthesis and application of nanostructured $\mathrm{Ag}_{2} \mathrm{~S}$.

Stable colloidal solutions contain the finest $\mathrm{Ag}_{2} \mathrm{~S}$ nanoparticles of size about $2-16 \mathrm{~nm}$ but the concentration of such nanoparticles is $0.01-0.02 \mathrm{mg} \mathrm{mL}^{-1}$ and rather small. That is why an important problem in the synthesis of different forms of nanostructured $\mathrm{Ag}_{2} \mathrm{~S}$ remains the preparation of more concentrated colloidal solutions that retain their long-term stability and small size of nanoparticles.

Obtaining a narrow size distribution of synthesized $\mathrm{Ag}_{2} \mathrm{~S}$ nanoparticles (i.e., the synthesis of uniform-sized nanoparticles) is another important challenge. Indeed, the synthesis of monodisperse $\mathrm{Ag}_{2} \mathrm{~S}$ nanoparticles (with size variation $<5 \%$ ) is of key importance because the properties of the nanoparticles depend strongly on their sizes and uniformity.

One of the major challenges of using $\mathrm{Ag}_{2} \mathrm{~S}$ quantum dots in electronics is the creation of large arrays of the quantum dots homogeneous in size and shape. The synthesized quantum dots are located on the substrate surface in a random way. For application in electronics, the prepared arrays of $\mathrm{Ag}_{2} \mathrm{~S}$ quantum dots should be well ordered, preferably by self-organization, and should be compatible with optical devices and detectors. Another important problem facing $\mathrm{Ag}_{2} \mathrm{~S}$ quantum dot arrays is improvement of the electric conductivity reduced by the organic ligands used in colloidal synthesis. Achieving the necessary performances of $\mathrm{Ag}_{2} \mathrm{~S}$ quantum dot assemblies is an attainable aim in the next years.

\section{Acknowledgements}

This study was supported by the Russian Science Foundation (14-23-00025) via the Institute of Solid State Chemistry (Ural Branch) of the Russian Academy of Sciences.

\section{References}

1 Z. Zhuang, Q. Peng and Y. Li, Chem. Soc. Rev., 2011, 40, 5492-5513.

2 M.-R. Gao, Y.-F. Xu, J. Jiang and S.-H. Yu, Chem. Soc. Rev., 2013, 42, 2986-3017.

3 N. V. Hullavarad, S. S. Hullavarad and P. C. Karulkar, J. Nanosci. Nanotechnol., 2008, 8, 3272-3299.

4 S. I. Sadovnikov, A. I. Gusev and A. A. Rempel, Russ. Chem. Rev., 2016, 85, 731-758.

5 G. Xu, S. Zeng, B. Zhang, M. T. Swihart, K.-T. Yong and P. N. Prasad, Chem. Rev., 2016, 116, 12234-12327. 
6 Semiconductor Nanostructures, ed. D. Bimberg, Springer, Berlin, Heidelberg, 2008, p. 357.

7 Nanostructured Materials for Advanced Technological Applications, ed. J. P. Reithmaier, P. Petkov, W. Kulisch and C. Popov, Springer, Netherlands, 2009, p. 547.

8 L. Kharghanian and A. Moghimi, Asian J. Chem., 2013, 25, 5904-5906.

9 Nanostructured Semiconductors: From Basic Research to Applications, ed. P. Granitzer and K. Rumpf, CRC Press, New York, 2014, p. 700.

10 Metal Chalcogenide Nanostructures for Renewable Energy Applications, ed. A. Qurashi, Wiley, New York, 2015, p. 320.

11 A. P. Alivisatos, Science, 1996, 271, 933-937.

12 N. N. Ledentsov, V. M. Ustinov, V. A. Shchukin, P. S. Kop'ev, Z. I. Alferov and D. Bimberg, Semiconductors, 1998, 32, 343365.

13 Z. I. Alferov, Rev. Mod. Phys., 2001, 73, 767-782.

14 C. Cui, X. Li, J. Liu, Y. Hou, Y. Zhao and G. Zhong, Nanoscale Res. Lett., 2015, 10, 431.

15 D. S. Wang, C. H. Hao, W. Zheng, Q. Peng, T. H. Wang, Z. M. Liao, D. P. Yu and Y. D. Li, Adv. Mater., 2008, 20, 2628-2632.

16 J. Yang, E. H. Sargent, S. O. Kelley and J. Y. Ying, Nat. Mater., 2009, 8, 683-689.

17 Z. H. Sun, Z. Yang, J. H. Zhou, M. H. Yeung, W. H. Ni, H. K. Wu and J. F. Wang, Angew. Chem., Int. Ed., 2009, 48, 2881-2885.

18 A. M. Smith, M. C. Mancini and S. Nie, Nat. Nanotechnol., 2009, 4, 710-711.

19 P. Jiang, Z.-Q. Tian, C.-N. Zhu, Z.-L. Zhang and D.-W. Pang, Chem. Mater., 2012, 24, 3-5.

20 X. Wang, H. Huang, B. Liang, Z. Liu, D. Chen and G. Shen, Crit. Rev. Solid State Mater. Sci., 2013, 38, 57-90.

21 X. Shi, S. Zheng, W. Gao, W. Wei, M. Chem, F. Deng, X. Liu and Q. Xiao, J. Nanopart. Res., 2014, 16, 2741.

22 S. Ummartyotin and Y. Infahsaeng, Renewable Sustainable Energy Rev., 2015, 55, 17-24.

23 N. Kaur, S. Kaur, J. Singh and M. Rawat, J. Bioelectron. Nanotechnol., 2016, 1, 1-5.

24 S. Goel, F. Chen and W. Cai, Small, 2014, 10, 631-645.

25 J. Duan, H. Zhang, Q. Tang, B. He and L. Yu, J. Mater. Chem. A, 2015, 3, 17497-17510.

26 R. C. Sharma and Y. A. Chang, Bull. Alloy Phase Diagrams, 1986, 7, 263-269.

27 H. Reye and H. Schmalzried, Z. Phys. Chem., 1981, 128, 93100.

28 C. Wagner, J. Chem. Phys., 1953, 21, 1819-1827.

29 H. Rau, J. Phys. Chem. Solids, 1974, 35, 1553-1559.

30 G. Bonnecaze, A. Lichanot and S. Gromb, J. Phys. Chem. Solids, 1978, 39, 299-310.

31 G. Bonnecaze, A. Lichanot and S. Gromb, J. Phys. Chem. Solids, 1978, 39, 813-821.

32 A. V. Ditman and I. N. Kulikova, Zh. Fizich. Khimii, 1979, 53, 260-261, in Russian.

33 K. Mitteilung, Z. Phys. Chem., 1980, 119, 251-255.

34 M. K. van Doorselaer, J. Photogr. Sci., 1987, 35, 42-52.

35 P. Junod, Helv. Phys. Acta, 1959, 32, 567-600.
36 P. Junod, H. Hediger, B. Kilchör and J. Wullschleger, Philos. Mag., 1977, 36, 941-958.

37 S. H. Ehrlich, J. Imaging Sci. Technol., 1993, 37, 73-91.

38 S. Chang, Q. Li, X. Xiao, K. Y. Wong and T. Chen, Energy Environ. Sci., 2012, 5, 9444-9448.

39 W. P. Lim, Z. Zhang, H. Y. Low and W. S. Chin, Angew. Chem., Int. Ed., 2004, 43, 5685-5689.

40 J. Yang and J. Y. Ying, Angew. Chem., Int. Ed., 2011, 50, 46374643.

41 G. X. Zhu and Z. Xu, J. Am. Chem. Soc., 2011, 133, 148-157.

42 A. I. Kryukov, A. L. Stroyuk, N. N. Zin'chuk, A. V. Korzhak and S. Y. Kuchmii, J. Mol. Catal. A: Chem., 2004, 221, 209221.

43 S. Shen, Y. Zhang, Y. Liu, L. Peng, X. Chen and Q. Wang, Chem. Mater., 2012, 24, 2407-2413.

44 T. B. Nasrallah, H. Dlala, M. Amlouk, S. Belgacem and J. C. Bernede, Synth. Met., 2005, 151, 225-230.

45 T.-Y. Hsu, H. Buhay and N. P. Murarka, in Millimeter Optics, ed. G. A. Tanton, SPIE Proc., 1980, vol. 259, pp. 38-45.

46 D. Karashanova, D. Nihtianova, K. Starbova and N. Starbov, Solid State Ionics, 2004, 171, 269-275.

47 L. Liu, S. Hu, Y.-P. Dou, T. Liu, J. Lin and Y. Wang, Beilstein J. Nanotechnol., 2015, 6, 1781-1787.

48 C. H. Liang, K. Terabe, T. Hasegawa and M. Aono, Nanotechnology, 2007, 18, 485202.

49 Z. Xu, Y. Bando, W. Wang, X. Bai and D. Golberg, ACS Nano, 2010, 4, 2515-2522.

50 A. N. Belov, O. V. Pyatilova and M. I. Vorobiev, $A d v$. Nanopart., 2014, 3, 1-4.

51 M. M. El-Nahass, A. A. M. Farag, E. M. Ibrahim and S. AbdEl-Rahman, Vacuum, 2004, 72, 453-460.

52 U. M. Jadhav, S. N. Patel and R. S. Patil, Res. J. Chem. Sci., 2013, 3, 69-74.

53 P. Leidinger, R. Popescu, D. Gerthsen and C. Feldmann, Chem. Mater., 2013, 25, 4173-4180.

54 M. L. Pang, J. Y. Hu and H. C. Zeng, J. Am. Chem. Soc., 2010, 132, 10771-10785.

55 S. Xiong, B. Xi, K. Zhang, Y. Chen, J. Jiang, J. Hu and H. C. Zeng, Sci. Rep., 2013, 3, 2177.

56 P. Jiang, C.-N. Zhu, Z.-L. Zhang, Z.-Q. Tian and D.-W. Pang, Biomaterials, 2012, 33, 5130-5135.

57 C. Li, Y. Zhang, M. Wang, Y. Zhang, G. Chen, L. Li, D. Wu and Q. Wang, Biomaterials, 2014, 35, 393-400.

58 C. Xiao, J. Xu, K. Li, J. Feng, J. Yang and Y. Xie, J. Am. Chem. Soc., 2012, 134, 4287-4293.

59 X. Zhang and L.-D. Zhao, J. Materiomics, 2015, 1, 92-105.

60 M. Adelifard and R. Torkamani, J. Mater. Sci.: Mater. Electron., 2015, 26, 7554-7563.

61 Y. Zhao, C. Rinzler and A. Allanore, ECS J. Solid State Sci. Technol., 2017, 6, 3010-3016.

62 S. Kashida, N. Watanabe, T. Hasegawa, H. Iida, M. Mori and S. Savrasov, Solid State Ionics, 2003, 158, 167-175.

63 L. Zhu, Z. Meng, G. Trisha and W.-C. Oh, Chin. J. Catal., 2012, 33, 254-2604.

64 A. Pourahmad, Superlattice Microst., 2012, 52, 276-287.

65 J. Jang, K. Cho, S. H. Lee and S. Kim, Mater. Lett., 2008, 62, 1438-1440. 
66 L. Han, Y. Lv, A. M. Asiri, A. O. Al-Youbi, B. Tu and D. Y. Zhao, J. Mater. Chem., 2012, 22, 7274-7279.

67 S. I. Sadovnikov and A. A. Rempel, Neorg. Mater., 2015, 51, 829-837; Inorg. Mater., 2015, 51, 759-766, in Russian.

68 S. I. Sadovnikov, A. I. Gusev, E. Yu. Gerasimov and A. A. Rempel, Chem. Phys. Lett., 2015, 642, 17-21.

69 R. Chen, N. T. Nuhfer, L. Moussa, H. R. Morris and P. M. Whitmore, Nanotechnology, 2008, 19, 455604.

70 W. Zhang, L. Zhang, Z. Hui, X. Zhang and Y. Qian, Solid State Ionics, 2000, 130, 111-114.

71 X. F. Qian, J. Yin, J. C. Huang, Y. F. Yang, X. X. Guo and Z. K. Zhu, Mater. Chem. Phys., 2001, 68, 95-97.

72 X. F. Qian, J. Yin, S. Feng, S. H. Liu and Z. K. Zhu, J. Mater. Chem., 2001, 11, 2504-2506.

73 C. Xu, Z. Zhang and Q. Ye, Mater. Lett., 2004, 58, 1671-1676.

74 X. Lu, L. Li, W. Zhang and C. Wang, Nanotechnology, 2005, 16, 2233-2237.

75 V. B. Prabhune, N. S. Shinde and V. J. Fulari, Appl. Surf. Sci., 2008, 255, 1819-1823.

76 H. Meherzi-Maghraoui, M. Dachraoui, S. Belgacem, K. D. Buhre, R. Kunst, P. Cowache and D. Lincot, Thin Solid Films, 1996, 288, 217-223.

77 H. Li, J. X. Li, G. D. Li, D. P. Liu and J. S. Chen, Chem.-Eur. J., 2007, 13, 8754-8761.

78 S. S. Dhumure and C. D. Lokhande, Mater. Chem. Phys., 1991, 28, 141-144.

79 L.-M. Lyu and M. H. Huang, Chem.-Asian J., 2013, 8, 18471853.

80 M. Lismont, C. A. Paez and L. Dreesen, J. Colloid Interface Sci., 2015, 447, 40-49.

81 Z. Li, L. Jia, Y. Li, T. He and X.-M. Li, Appl. Surf. Sci., 2015, 345, 122-126.

82 X. Peng, M. C. Schlamp, A. V. Kadavanich and A. P. Alivisatos, J. Am. Chem. Soc., 1997, 119, 7019-7029.

83 F. Pinaud, D. King, H. P. Moore and S. Weiss, J. Am. Chem. Soc., 2004, 126, 6115-6123.

84 G. Hota, S. Jain and K. C. Khilara, Colloids Surf., A, 2004, 232, 119-127.

85 D. O. Demchenko, R. D. Robinson, B. Sadtler, C. K. Erdonmez, A. P. Alivisatos and L.-W. Wang, ACS Nano, 2008, 2, 627-636.

86 A. Emamdoust, S. F. Shayesteh and M. Marandi, Pramana, 2013, 80, 713-721.

87 D. Gerion, F. Pinaud, S. C. Williams, W. J. Parak, D. Zanchet, S. Weiss and A. P. Alivisatos, J. Phys. Chem. B, 2001, 105, 8861-8871.

88 X. Gao, Y. Cui, R. M. Levenson, L. W. K. Chung and S. Nie, Nat. Biotechnol., 2004, 22, 969-976.

89 N. Tipcompor, S. Thongtem and T. Thongtem, J. Nanomater. (Hindawi), 2013, 2013, 970489.

90 J. Xiang, H. Cao, Q. Wu, S. Zhang, X. Zhang and A. A. R. Watt, J. Phys. Chem. C, 2008, 112, 3580-3584.

91 Y. Yu, K. Zhang and S. Sun, Appl. Surf. Sci., 2012, 258, 71817187.

92 D. Deng, J. Xia, J. Cao, L. Qu, J. Tian, Z. Qian, Y. Gu and Z. Gu, J. Colloid Interface Sci., 2012, 367, 234-240.
93 M. S. Sadjadi and A. Khalilzadegan, Journal of Non-Oxide Glasses, 2015, 7, 55-63.

94 J. Zeng, Y. Zheng, M. Rycenga, J. Tao, Z. Y. Li, Q. Zhang, Y. Zhu and Y. Xia, J. Am. Chem. Soc., 2010, 132, 8552-8853.

95 L. Gutierrez, C. Aubry, M. Cornejo and J.-P. Croue, Langmuir, 2015, 31, 8865-8872.

96 S. d'Souza, P. Mashazi, J. Britton and T. Nyokong, Polyhedron, 2015, 99, 112-121.

97 D. Philip, Spectrochim. Acta, Part A, 2010, 75, 1078-1081.

98 R. Mendoza-Reséndez, A. Gómez-Treviño, E. D. BarrigaCastro, N. O. Núñez and C. Luna, RSC Adv., 2014, 4, 16501658.

99 D. Ayodhya and G. Veerabhadram, J. Photochem. Photobiol., $B, 2016,157$, 57-69.

100 H.-Y. Yang, Y.-W. Zhao, Z.-Y. Zhang, H.-M. Xiong and S.-N. Yu, Nanotechnology, 2013, 24, 055706.

101 A. C. C. Esteves and T. Trindade, Curr. Opin. Solid State Mater. Sci., 2002, 6, 347-353.

102 Q. Tang, S. M. Yoon, H. J. Yang, Y. Lee, H. J. Song, H. R. Byon and H. C. Choi, Langmuir, 2006, 22, 2802-2805.

103 T. X. Wang, H. Xiao and Y. C. Zhang, Mater. Lett., 2008, 62, 3736-3738.

104 C. L. Zhang, S. M. Zhang, L. G. Yu and Z. J. Zhang, Mater. Lett., 2012, 85, 77-80.

105 C. Burda, X. B. Chen, R. Narayanan and E. I. Sayed, Chem. Rev., 2005, 105, 1025-1102.

106 Y. Zhao, D. W. Zhang and W. F. Shi, Mater. Lett., 2007, 61, 3232-3234.

107 C. G. Xu, Z. C. Zhang and Q. Ye, Mater. Lett., 2004, 58, 16711676.

108 M. H. Chen and L. Gao, Mater. Lett., 2006, 60, 1059-1062.

109 H. J. Zhai and H. S. Wang, Mater. Res. Bull., 2008, 43, 23542360.

110 X. B. Wang, W. M. Liu, J. C. Hao, X. G. Fu and B. S. Xu, Chem. Lett., 2005, 34, 1664-1665.

111 L. H. Dong, Y. Chu and Y. Liu, J. Colloid Interface Sci., 2008, 317, 485-492.

112 Y. Fang, C. Bai and Y. Zhang, Chem. Commun., 2004, 804805.

113 Y. Z. Sun and B. B. Zhou, Mater. Lett., 2010, 64, 1347-1349. 114 Z. Zhuang, Q. Peng, X. Wang and Y. Li, Angew. Chem., Int. Ed., 2007, 46, 8174-8177.

115 R. G. Chaudhuri and S. Paria, J. Colloid Interface Sci., 2012, 369, 117-122.

116 M. Y. Liu, Z. L. Xu, B. N. Li and C. M. Lin, Mater. Lett., 2011, 65, 555-558.

117 L. Y. Lv and H. Wang, Mater. Lett., 2014, 121, 105-108.

118 S. I. Sadovnikov, A. I. Gusev and A. A. Rempel, Superlattice Microst., 2015, 83, 35-47.

119 M. H. Huang, Y. Wu, H. Feick, N. Tran, E. Weber and P. Yang, Adv.Mater., 2001, 13, 113-117.

120 D. Wang, C. Hao, W. Zheng, Q. Peng, T. Wang, Z. Liao, D. Yus and Y. Li, Adv. Mater., 2008, 20, 2628-2632.

121 X. Wen, S. Wang, Y. Xie, X.-Y. Li and S. Yang, J. Phys. Chem. $B, 2005,109,10100-10106$.

122 C. H. Liang, K. Terabe, T. Hasegawa, R. Negishi, T. Tamura and M. Aono, Small, 2005, 1, 971-975. 
123 S. C. Yan, H. T. Wang, Y. P. Zhang, S. C. Li and Z. D. Xiao, J. Non-Cryst. Solids, 2008, 354, 5559-5562.

124 S. Yan, K. Shen, X. Xu, Y. Shi, J. Wu and Z. Xiao, Synth. Met., 2011, 161, 1646-1650.

125 C.-S. Tan, C.-H. Hsiao, S.-C. Wang, P.-H. Liu, M.-Y. Lu, M. H. Huang, H. Ouyang and L.-J. Chen, ACS Nano, 2014, 8, 9422-9426.

126 M. Yarema, S. Pichler, M. Sytnyk, R. Seyrkammer, R. T. Lechner, G. Fritz-Popovski, D. Jarzab, K. Szendrei, R. Resel, O. Korovyanko, M. A. Loi, O. Paris, G. Hesser and W. Heiss, ACS Nano, 2011, 5, 3758-3765.

127 Y. Du, B. Xu, T. Fu, M. Cai, F. Li, Y. Zhang and Q. Wang, J. Am. Chem. Soc., 2010, 132, 1470-1471.

128 W. Cai, D. W. Shin, K. Chen, O. Gheysens, Q. Cao, S. X. Wang, S. S. Gambhir and X. Chen, Nano Lett., 2006, 6, 669-676.

129 J. Chen, T. Zhang, L. L. Feng, M. Zhang, X. Zhang, H. Su and D. Cui, Mater. Lett., 2013, 96, 224-227.

130 C. Siva, C. N. Iswarya, P. Baraneedharan and M. Sivakumar, Mater. Lett., 2014, 134, 56-59.

131 X. M. Hou, X. L. Zhang, W. Yang and Y. Liu, Mater. Res. Bull., 2012, 47, 2579-2583.

132 M. Shakouri-Arani and M. Salavati-Niasari, Spectrochim. Acta, Part A, 2014, 133, 463-471.

133 X. Wang, J. Zhuang, Q. Peng and Y. D. Li, Nature, 2005, 437, 121-124.

134 Y. Zhang, G. Hong, Y. Zhang, G. Chen, F. Li, H. Dai and Q. Wang, ACS Nano, 2012, 6, 3695-3702.

135 I. Hocaoglu, M. N. Çizmeciyan, R. Erdem, C. Ozen, A. Kurt, A. Sennaroglu and H. Y. Acar, J. Mater. Chem., 2012, 22, 14574-14681.

136 S. I. Sadovnikov and A. I. Gusev, Eur. J. Inorg. Chem., 2016, 2016, 4944-4957.

137 C. S. Sunandana, Introduction to Solid State Ionics: Phenomenology and Applications, CRC Press, Baton Rouge, 2015, p. 529.

138 J. Yang and H. Liu, Metal-Based Composite Nanomaterials, Springer, Berlin, Heidelberg, 2015, p. 259.

139 T. V. Vinogradova, I. A. Glukhova, L. N. Maskaeva and V. F. Markov, Eur. Rev. Chem. Res., 2016, 10, 122-129.

140 P. Anastas and N. Eghbali, Chem. Soc. Rev., 2010, 39, 301312.

141 P. Patnaik, Dean's Analytical Chemistry Handbook, McGrawHill, New York, 2nd edn, 2004, Table 4.2, p. 1280.

142 P. C. Lee and D. Meisel, J. Phys. Chem., 1982, 86, 3391-3395.

143 S. I. Sadovnikov and A. A. Rempel, Patent No. 2572421 of Russian Federation, 2016, pp. 1-4.

144 S. I. Sadovnikov, Y. V. Kuznetsova and A. A. Rempel, NanoStructures \& Nano-Objects, 2016, 7, 81-91.

145 Y. Zhang, Y. Liu, C. Li, X. Chen and Q. Wang, J. Phys. Chem. C, 2014, 118, 4918-4923.

146 S. I. Sadovnikov, Y. V. Kuznetsova, A. I. Gusev and A. A. Rempel, Patent No. 2600761 of Russian Federation, 2016, pp. 1-11.

147 S. I. Sadovnikov, A. I. Gusev, E. Y. Gerasimov and A. A. Rempel, Neorg. Mater., 2016, 52, 487-492; Inorg. Mater., 2016, 52, 441-446, in Russian.
148 S. I. Sadovnikov, A. I. Gusev and A. A. Rempel, Phys. Chem. Chem. Phys., 2015, 17, 12466-12471.

149 S. I. Sadovnikov, A. I. Gusev and A. A. Rempel, Patent No. 2603666 of Russian Federation, 2016, pp. 1-13.

150 A. J. Frueh, Z. Kristallogr., 1958, 110, 136-144.

151 L. S. Ramsdell, Am. Mineral., 1943, 28, 401-425.

152 P. Rahlfs, Z. Phys. Chem. B, 1936, 31, 157-194.

153 R. Sadanaga and S. Sueno, Mineral. J., 1967, 5, 124-148.

154 R. J. Cava, F. Reidinger and B. J. Wuensch, J. Solid State Chem., 1980, 31, 69-80.

155 T. Blanton, S. Misture, N. Dontula and S. Zdzieszynski, Powder Diffr., 2011, 26, 110-118.

156 C. Wang, X. Zhang, X. Qian, W. Wang and Y. Qian, Mater. Res. Bull., 1998, 33, 1083-1086.

157 V. Krylova and L. Samuolaitiene, Mater. Sci., 2013, 19, 1014.

158 L. Grocholl, J. Wang and E. G. Gillan, Mater. Res. Bull., 2003, 38, 213-220.

159 B. Kim, C.-S. Park, M. Murayama and M. F. Hochella, Environ. Sci. Technol., 2010, 44, 7509-7514.

160 G. A. Martínez-Castañón, M. G. Sánchez-Loredo, H. J. Dorantes, J. R. Martínez-Mendoza, G. Ortega-Zarzosa and F. Ruiz, Mater. Lett., 2005, 59, 529-534.

161 L. V. Trandafilović, V. Djoković, N. Bibić, M. K. Georges and T. Radhakrishnan, Mater. Lett., 2010, 64, 1123-1126.

162 S. I. Sadovnikov, A. I. Gusev and A. A. Rempel, Phys. Chem. Chem. Phys., 2015, 17, 20495-20501.

163 S. I. Sadovnikov, A. I. Gusev and A. A. Rempel, Rev. Adv. Mater. Sci., 2015, 41, 7-19.

164 S. I. Sadovnikov, A. I. Gusev and A. A. Rempel, Dokl. Akad. Nauk, 2015, 464, 568-573; Dokl. Phys. Chem., 2015, 464, 238-243, in Russian.

165 S. I. Sadovnikov, A. V. Chukin, A. A. Rempel and A. I. Gusev, Fiz. Tverd. Tela, 2016, 58, 32-38; Phys. Solid State, 2016, 58, 30-36, in Russian.

166 S. I. Sadovnikov, A. I. Gusev, A. V. Chukin and A. A. Rempel, Phys. Chem. Chem. Phys., 2016, 18, 4617-4626.

167 C. M. Perrott and N. H. Fletcher, J. Chem. Phys., 1969, 50, 2344-2350.

168 W. T. Thompson and S. N. Flengas, Can. J. Chem., 1971, 49, 1550-1563.

169 H. Okazaki and A. Takano, Z. Naturforsch., 1985, 40, 986988.

170 F. Grønvold and E. F. Westrum, J. Chem. Thermodyn., 1986, 18, 381-401.

171 https://summary.ccdc.cam.ac.uk/structure-summary? ccdc $=1062400$.

172 A. J. Frueh, Am. Mineral., 1961, 46, 654-660.

173 A. I. Gusev, S. I. Sadovnikov, A. V. Chukin and A. A. Rempel, Fiz. Tverd. Tela, 2016, 58, 246-251; Phys. Solid State, 2016, 58, 251-257, in Russian.

174 K. Honma and K. Iida, J. Phys. Soc. Jpn., 1987, 56, 828-1836.

175 S. I. Sadovnikov and A. I. Gusev, Phys. Solid State, 2017, 59, 1863-1870.

176 S. I. Sadovnikov and A. I. Gusev, J. Alloys Compd., 2014, 610, 196-202. 
177 S. I. Sadovnikov and A. I. Gusev, Fiz. Tverd. Tela, 2014, 56, 2274-2278; Phys. Solid State, 2014, 56, 2353-2358, in Russian.

178 A. I. Gusev and A. A. Rempel, Nanocrystalline Materials, Cambridge Intern, Science Publ., Cambridge, 2004, p. 351.

179 Y. I. Petrov, Physics of Small Particles, Nauka, Moscow, 1982, p. 360, in Russian.

180 E. W. Montrol, J. Chem. Phys., 1950, 18, 183-185.

181 K. Terabe, T. Hasegawa, T. Nakayama and M. Aono, Nature, 2005, 433, 47-50.

182 B. G. Kumar, B. Srinivas, M. D. Prasad and K. Muralidharan, J. Nanopart. Res., 2015, 17, 325.

183 B. Liu and Z. Ma, Small, 2011, 7, 1587-1592.

184 C. Marambio-Jones and E. M. V. Hoek, J. Nanopart. Res., 2010, 12, 1531-1551.

185 X. Ma, Y. Zhao, X. Jiang, W. Liu, S. Liu and Z. Tang, ChemPhysChem, 2012, 13, 2531-2535.

186 R. Costi, A. E. Saunders and U. Banin, Angew. Chem., Int. Ed., 2010, 49, 4878-4897.

187 N. Mishra, J. Lian, S. Chakrabortty, M. Lin and Y. Chan, Chem. Mater., 2012, 24, 2040-2046.

188 S. K. Dutta, S. K. Mehetor and N. Pradhan, J. Phys. Chem. Lett., 2015, 6, 936-944.

189 J. Yang and J. Y. Ying, Chem. Commun., 2009, 3187-3189.

190 J. Yang, J. Y. Lee and J. Y. Ying, Chem. Soc. Rev., 2011, 40, 1672-1696.

191 R. D. Robinson, B. Sadtler, D. O. Demchenko, C. K. Erdonmez, L. W. Wang and A. P. Alivisatos, Science, 2007, 317, 355-358.

192 S. Shen, Y. Zhang, L. Peng, Y. Du and Q. Wang, Angew. Chem., Int. Ed., 2011, 50, 7115-7118.

193 H. Zhang, M. Chen, D. M. Wang, L. Xu and X. D. Liu, Opt. Mater. Express, 2016, 6, 2573-2583.

194 D. Wang, L. Liu, Y. Kim, Z. Huang, D. Pantel, D. Hesse and M. Alexe, Appl. Phys. Lett., 2011, 98, 243109.

195 S. Kaeriyama, T. Sakamoto, H. Sunamura, M. Mizuno, H. Kawaura, T. Hasegawa, K. Terabe, T. Nakayama and M. Aono, IEEE J. Solid-State Circuits, 2005, 40, 168-186.
196 A. Nayak, T. Tamura, T. Tsuruoka, K. Terabe, S. Hosaka, T. Hasegawa and M. Aono, J. Phys. Chem. Lett., 2010, 1, 604-608.

197 H. Tanaka, T. Akai, D. Tanaka and T. Ogawa, e-J. Surf. Sci. Nanotechnol., 2014, 12, 185-188.

198 A. Gubicza, D. Z. Manrique, L. Pósa, C. J. Lambert, G. Mihály, M. Csontos and A. Halbritter, Sci. Rep., 2016, 6, 30775 .

199 M. Morales-Masis, S. J. Molen, W. T. Fu, M. B. Hesselberth and J. M. Ruitenbeek, Nanotechnology, 2009, 20, 095710.

200 S. I. Sadovnikov and A. I. Gusev, J. Nanopart. Res., 2016, 18, 277.

201 A. I. Gusev and S. I. Sadovnikov, Fiz. Tekh. Poluprovodn., 2016, 50, 694-699; Semiconductors, 2016, 50, 682-687, in Russian.

202 A. I. Gusev and S. I. Sadovnikov, Mater. Lett., 2017, 188, 351354.

203 S. I. Sadovnikov and A. I. Gusev, Biointerface Res. Appl. Chem., 2016, 6, 1797-1804.

204 Y. I. Kharkats, Fiz. Tverd. Tela, 1981, 23, 2190-2192, in Russian.

205 Y. Y. Gurevich and Y. I. Kharkats, Usp. Fiz. Nauk, 1982, 136, 693-728; Phys.-Usp., 1982, 25, 257-276, in Russian.

206 A. Henglein, Ber. Bunsenges. Phys. Chem., 1997, 101, 15621572.

207 Y. A. Krutyakov, A. A. Kudrinskiy, A. Y. Olenin and G. V. Lisichkin, Usp. Khim., 2008, 77, 242-269; Russ. Chem. Rev., 2008, 77, 233-257, in Russian.

208 M. Hu, J. Y. Chen, Z. Y. Li, L. Au, G. V. Hartland, X. D. Li, M. Marquez and Y. N. Xia, Chem. Soc. Rev., 2006, 35, 1084-1094.

209 S. P. Song, Q. Yu, Y. He, Q. Huang, C. H. Fan and H. Y. Chen, Chem. Soc. Rev., 2010, 39, 4234-4243.

210 J. Yang and H. Liu, Metal-Based Composite Nanomaterials, Springer, Cham, Heidelberg, Dordrecht, London, 2015, ch. 4, pp. 93-114. 